Cochrane Database of Systematic Reviews

\title{
PCSK9 monoclonal antibodies for the primary and secondary prevention of cardiovascular disease (Review)
}

Schmidt AF, Carter JPL, Pearce LS, Wilkins JT, Overington JP, Hingorani AD, Casas JP

Schmidt AF, Carter J-PL, Pearce LS, Wilkins JT, Overington JP, Hingorani AD, Casas J.

PCSK9 monoclonal antibodies for the primary and secondary prevention of cardiovascular disease.

Cochrane Database of Systematic Reviews 2020, Issue 10. Art. No.: CD011748.

DOI: 10.1002/14651858.CD011748.pub3.

www.cochranelibrary.com 
TABLE OF CONTENTS

HEADER 1

ABSTRACT

PLAIN LANGUAGE SUMMARY

SUMMARY OF FINDINGS

BACKGROUND

OBJECTIVES

METHODS

RESULTS

Figure 1.

Figure 2.

Figure 3.

Figure 4.

Figure 5.

DISCUSSION

AUTHORS' CONCLUSIONS

ACKNOWLEDGEMENTS

REFERENCES

CHARACTERISTICS OF STUDIES

DATA AND ANALYSES

Analysis 1.1. Comparison 1: Alirocumab versus placebo, Outcome 1: Any cardiovascular disease

Analysis 1.2. Comparison 1: Alirocumab versus placebo, Outcome 2: All-cause mortality

Analysis 1.3. Comparison 1: Alirocumab versus placebo, Outcome 3: Any myocardial infarction

Analysis 1.4. Comparison 1: Alirocumab versus placebo, Outcome 4: Any stroke

Analysis 1.5. Comparison 1: Alirocumab versus placebo, Outcome 5: Influenza

Analysis 1.6. Comparison 1: Alirocumab versus placebo, Outcome 6: Type 2 diabetes mellitus

Analysis 1.7. Comparison 1: Alirocumab versus placebo, Outcome 7: Any cancer

Analysis 1.8. Comparison 1: Alirocumab versus placebo, Outcome 8: Hypertension

Analysis 2 1. Comparison 2: Evolocumab versus placebo, Outcome 1: Any cardiovascular disease .

Analysis 2.2. Comparison 2: Evolocumab versus placebo, Outcome 2: All-cause mortality

Analysis 2.3. Comparison 2: Evolocumab versus placebo, Outcome 3: Any myocardial infarction

Analysis 2.4. Comparison 2: Evolocumab versus placebo, Outcome 4: Any stroke

Analysis 2.5. Comparison 2: Evolocumab versus placebo, Outcome 5: Influenza

Analysis 2.6. Comparison 2: Evolocumab versus placebo, Outcome 6: Type 2 diabetes mellitus

Analysis 3.1. Comparison 3: Alirocumab versus active therapy, Outcome 1: Any cardiovascular disease

Analysis 3.2. Comparison 3: Alirocumab versus active therapy, Outcome 2: All-cause mortality

Analysis 3.3. Comparison 3: Alirocumab versus active therapy, Outcome 3: Any myocardial infarction

Analysis 3.4. Comparison 3: Alirocumab versus active therapy, Outcome 4: Any stroke

Analysis 3.5. Comparison 3: Alirocumab versus active therapy, Outcome 5: Influenza

Analysis 3.6. Comparison 3: Alirocumab versus active therapy, Outcome 6: Type 2 diabetes mellitus

Analysis 3.7. Comparison 3: Alirocumab versus active therapy, Outcome 7: Any cancer

Analysis 3.8. Comparison 3: Alirocumab versus active therapy, Outcome 8: Hypertension

Analysis 4.1. Comparison 4: Evolocumab versus active therapy, Outcome 1: Any cardiovascular disease

Analysis 4.2. Comparison 4: Evolocumab versus active therapy, Outcome 2: All-cause mortality

Analysis 4.3. Comparison 4: Evolocumab versus active therapy, Outcome 3: Any myocardial infarction

Analysis 4.4. Comparison 4: Evolocumab versus active therapy, Outcome 4: Influenza

Analysis 4.5. Comparison 4: Evolocumab versus active therapy, Outcome 5: Type 2 diabetes mellitus

Analysis 4.6. Comparison 4: Evolocumab versus active therapy, Outcome 6: Hypertension

ADDITIONAL TABLES

APPENDICES

WHAT'S NEW

HISTORY 
[Intervention Review]

\section{PCSK9 monoclonal antibodies for the primary and secondary prevention of cardiovascular disease}

Amand F Schmidt1,2, John-Paul L Carter ${ }^{3}$, Lucy S Pearce ${ }^{4}$, John T Wilkins ${ }^{5}$, John P Overington 6 , Aroon D Hingorani ${ }^{1}$, JP Casas 7

1Institute of Cardiovascular Science, University College London, London, UK. 2Department of Cardiology, Division Heart and Lungs, UMC Utrecht, Utrecht, Netherlands. ${ }^{3}$ Department of Clinical Pharmacology and Therapeutics, University College London Hospital, London, UK. ${ }^{4}$ Department of Non-communicable Disease Epidemiology, London School of Hygiene \& Tropical Medicine, London, UK. 5The Department of Medicine (Cardiology) and the Department of Preventive Medicine, Northwestern University Feinberg School of Medicine, Chicago, Illinois, USA. ${ }^{6}$ Medicines Discovery Catapult, Alderly Edge, UK. ${ }^{7}$ Massachusetts Veterans Epidemiology Research and Information Center (MAVERIC), VA Boston Healthcare System, Boston, Massachusetts, USA

Contact address: Amand F Schmidt, amand.schmidt@ucl.ac.uk.

Editorial group: Cochrane Heart Group.

Publication status and date: New search for studies and content updated (conclusions changed), published in Issue 10, 2020.

Citation: Schmidt AF, Carter J-PL, Pearce LS, Wilkins JT, Overington JP, Hingorani AD, Casas J. PCSK9 monoclonal antibodies for the primary and secondary prevention of cardiovascular disease. Cochrane Database of Systematic Reviews 2020, Issue 10. Art. No.: CD011748. DOI: 10.1002/14651858.CD011748.pub3.

Copyright @ 2020 The Cochrane Collaboration. Published by John Wiley \& Sons, Ltd.

\section{A B S T R A C T}

\section{Background}

Despite the availability of effective drug therapies that reduce low-density lipoprotein (LDL)-cholesterol (LDL-C), cardiovascular disease (CVD) remains an important cause of mortality and morbidity. Therefore, additional LDL-C reduction may be warranted, especially for people who are unresponsive to, or unable to take, existing LDL-C-reducing therapies. By inhibiting the proprotein convertase subtilisin/ kexin type 9 (PCSK9) enzyme, monoclonal antibodies (PCSK9 inhibitors) reduce LDL-C and CVD risk.

\section{Objectives}

\section{Primary}

To quantify the effects of PCSK9 inhibitors on CVD, all-cause mortality, myocardial infarction, and stroke, compared to placebo or active treatment(s) for primary and secondary prevention.

\section{Secondary}

To quantify the safety of PCSK9 inhibitors, with specific focus on the incidence of influenza, hypertension, type 2 diabetes, and cancer, compared to placebo or active treatment(s) for primary and secondary prevention.

\section{Search methods}

We identified studies by systematically searching CENTRAL, MEDLINE, Embase, and Web of Science in December 2019. We also searched ClinicalTrials.gov and the International Clinical Trials Registry Platform in August 2020 and screened the reference lists of included studies. This is an update of the review first published in 2017.

\section{Selection criteria}

All parallel-group and factorial randomised controlled trials (RCTs) with a follow-up of at least 24 weeks were eligible. 


\section{Data collection and analysis}

Two review authors independently reviewed and extracted data. Where data were available, we calculated pooled effect estimates. We used GRADE to assess certainty of evidence and in 'Summary of findings' tables.

\section{Main results}

We included 24 studies with data on 60,997 participants. Eighteen trials randomised participants to alirocumab and six to evolocumab. All participants received background lipid-lowering treatment or lifestyle counselling. Six alirocumab studies used an active treatment comparison group (the remaining used placebo), compared to three evolocumab active comparison trials.

Alirocumab compared with placebo decreased the risk of CVD events, with an absolute risk difference (RD) of $-2 \%$ (odds ratio (OR) 0.87 , $95 \%$ confidence interval ( $\mathrm{CI}) 0.80$ to $0.94 ; 10$ studies, 23,868 participants; high-certainty evidence), decreased the risk of mortality (RD $1 \%$; OR $0.83,95 \% \mathrm{Cl} 0.72$ to $0.96 ; 12$ studies, 24,797 participants; high-certainty evidence), and MI (RD $-2 \%$; OR $0.86,95 \%$ Cl 0.79 to $0.94 ; 9$ studies, 23,352 participants; high-certainty evidence) and for any stroke (RD 0\%; OR 0.73, 95\% Cl 0.58 to 0.91; 8 studies, 22,835 participants; high-certainty evidence).

Compared to active treatment the alirocumab effects, for CVD, the RD was $1 \%$ (OR 1.37, 95\% CI 0.65 to $2.87 ; 3$ studies, 1379 participants; low-certainty evidence); for mortality, RD was $-1 \%$ (OR $0.51,95 \% \mathrm{Cl} 0.18$ to $1.40 ; 5$ studies, 1333 participants; low-certainty evidence); for MI, RD was $1 \%$ (OR $1.45,95 \% \mathrm{Cl} 0.64$ to $3.28,5$ studies, 1734 participants; low-certainty evidence); and for any stroke, RD was less than $1 \%$ (OR $0.85,95 \% \mathrm{Cl} 0.13$ to $5.61 ; 5$ studies, 1734 participants; low-certainty evidence).

Compared to placebo the evolocumab, for CVD, the RD was -2\% (OR 0.84, 95\% Cl 0.78 to $0.91 ; 3$ studies, 29,432 participants; high-certainty evidence); for mortality, RD was less than $1 \%$ (OR 1.04, $95 \% \mathrm{Cl} 0.91$ to 1.19; 3 studies, 29,432 participants; high-certainty evidence); for MI, RD was $-1 \%$ (OR $0.72,95 \%$ Cl 0.64 to 0.82 ; 3 studies, 29,432 participants; high-certainty evidence); and for any stroke RD was less than $-1 \%$ (OR $0.79,95 \% \mathrm{Cl} 0.65$ to $0.94 ; 2$ studies, 28,531 participants; high-certainty evidence).

Compared to active treatment, the evolocumab effects, for any CVD event RD was less than $-1 \%$ (OR 0.66, $95 \% \mathrm{Cl} 0.14$ to $3.04 ; 1$ study, 218 participants; very low-certainty evidence); for all-cause mortality, the RD was less than $1 \%(\mathrm{OR} 0.43,95 \% \mathrm{Cl} 0.14$ to $1.30 ; 3$ studies, 5223 participants; very low-certainty evidence); and for MI, RD was less than $1 \%$ (OR $0.66,95 \% \mathrm{Cl} 0.23$ to 1.85 ; 3 studies, 5003 participants; very low-certainty evidence). There were insufficient data on any stroke.

\section{Authors' conclusions}

The evidence for the clinical endpoint effects of evolocumab and alirocumab were graded as high. There is a strong evidence base to prescribe PCSK9 monoclonal antibodies to people who might not be eligible for other lipid-lowering drugs, or to people who cannot meet their lipid goals on more traditional therapies, which was the main patient population of the available trials.

The evidence base of PCSK9 inhibitors compared with active treatment is much weaker (low very- to low-certainty evidence) and it is unclear whether evolocumab or alirocumab might be effectively used as replacement therapies. Related, most of the available studies preferentially enrolled people with either established CVD or at a high risk already, and evidence in low- to medium-risk settings is minimal.

Finally, there is very limited evidence on any potential safety issues of both evolocumab and alirocumab. While the current evidence synthesis does not reveal any adverse signals, neither does it provide evidence against such signals. This suggests careful consideration of alternative lipid lowering treatments before prescribing PCSK9 inhibitors.

\section{PLAIN LANGUAGE SUMMARY}

\section{PCSK9 inhibitors for prevention of cardiovascular disease}

\section{Research question}

What is the effectiveness and safety of PCSK9 inhibitors for cardiovascular disease (CVD) prevention?

\section{Background}

Despite the availability of effective medicines (such as statins (which works by blocking a substance your body needs to make cholesterol) or ezetimibe (which stops your body taking in cholesterol from food), or both) that reduce low-density lipoprotein (LDL) cholesterol (LDLC) (sometimes called 'bad' cholesterol), CVD remains an important cause of death and illness. Additional LDL-C reduction may be needed, especially for people who are unresponsive to, or are unable to use, existing LDL-C-reducing therapies. Medicines called PCSK9 inhibitors are another way of lowering LDL-C and CVD risk.

\section{Study characteristics}


Review authors identified 23 studies that evaluated the effects of the PCSK9 inhibitors, alirocumab and evolocumab, in people at high risk of CVD. Studies were conducted in outpatient clinics. Review authors identified the studies included in this review through electronic literature searches conducted up to December 2019. This is an update of the review first published in 2017.

\section{Key results}

Both alirocumab and evolocumab decreased the risk of CVD when added to other LDL-C-lowering medicines (e.g. statins or ezetimibe). Alirocumab additionally showed a decrease in death from any cause; with insufficient evidence for evolocumab. Limited data, often of lower quality, was available comparing these PCSK9 inhibitors against other LDL-C-lowering drugs. Differences in risk between people treated with and without PCSK9 inhibitors suggest the absolute treatment benefit will likely be modest (e.g. less than $1 \%$ change in risk).

\section{Quality of evidence}

We found high-quality evidence when adding PCSK9 inhibitors to existing LDL-C-lowering treatments and low-to very low-quality evidence when replacing existing LDL-C-reducing medicines with PCSK9 inhibitors. 


\section{SUMMARY OF FINDINGS}

\section{Summary of findings 1 . Alirocumab compared with placebo}

Alirocumab compared with placebo

Patient or population: people at high risk of CVD (history of CVD or high LDL-C despite treatment)

Setting: outpatient care settings

Intervention: alirocumab PCSK9 monoclonal antibodies

Comparison: placebo

\begin{tabular}{|c|c|c|c|c|c|c|c|}
\hline \multirow[t]{2}{*}{ Outcomes } & \multicolumn{2}{|c|}{ Illustrative comparative risk (95\% Cl) } & \multirow{2}{*}{$\begin{array}{l}\text { Relative ef- } \\
\text { fect }(95 \% \mathrm{Cl})\end{array}$} & \multirow[t]{2}{*}{ RD $(95 \% \mathrm{Cl})$} & \multirow{2}{*}{$\begin{array}{l}\text { Number of } \\
\text { participants } \\
\text { (studies) }\end{array}$} & \multirow{2}{*}{$\begin{array}{l}\text { Certainty of } \\
\text { the evidence } \\
\text { (GRADE) }\end{array}$} & \multirow[t]{2}{*}{ Comments } \\
\hline & Assumed risk & Corresponding risk using PCSK9 inhibition & & & & & \\
\hline $\begin{array}{l}\text { All-cause } \\
\text { mortality } \\
\text { Follow-up: } \\
6-36 \\
\text { months }\end{array}$ & $\begin{array}{l}\text { All-cause mortality } \\
\text { risk was } 59 \text { per } 1000 \\
\text { participants }\end{array}$ & $\begin{array}{l}\text { All-cause mortality risk in the intervention } \\
\text { group was } 53 \text { ( } 49 \text { to } 58 \text { ) per } 1000 \text { participants }\end{array}$ & $\begin{array}{l}\text { OR } 0.83(0.72 \\
\text { to } 0.96)\end{array}$ & $\begin{array}{l}-\mathbf{0 . 0 1}(-0.01 \\
\text { to } 0.00)\end{array}$ & $\begin{array}{l}24,797 \\
(12 \mathrm{RCTs})\end{array}$ & $\begin{array}{l}\oplus \oplus \oplus \oplus \\
\text { High }\end{array}$ & $\begin{array}{l}<1 \text { is benefi- } \\
\text { cial }\end{array}$ \\
\hline $\begin{array}{l}\text { Myocar- } \\
\text { dial in- } \\
\text { farction } \\
\text { Follow-up: } \\
6-36 \\
\text { months }\end{array}$ & $\begin{array}{l}\text { Myocardial infarction } \\
\text { risk was } 143 \text { per } 1000 \\
\text { participants }\end{array}$ & $\begin{array}{l}\text { Myocardial infarction risk in the intervention } \\
\text { group was } 128 \text { ( } 120 \text { to 136) per } 1000 \text { partici- } \\
\text { pants }\end{array}$ & $\begin{array}{l}\text { OR } 0.86(0.79 \\
\text { to } 0.94)\end{array}$ & $\begin{array}{l}-0.02(-0.02 \\
\text { to }-0.01)\end{array}$ & $\begin{array}{l}23,352 \\
\text { (9 RCTs) }\end{array}$ & $\begin{array}{l}\oplus \oplus \oplus \oplus \\
\text { High }\end{array}$ & $\begin{array}{l}<1 \text { is benefi- } \\
\text { cial }\end{array}$ \\
\hline $\begin{array}{l}\begin{array}{l}\text { Any } \\
\text { stroke }\end{array} \\
\text { Follow-up: } \\
6-36 \\
\text { months }\end{array}$ & $\begin{array}{l}\text { Stroke risk was } 27 \\
\text { per } 1000 \text { partici- } \\
\text { pants }\end{array}$ & $\begin{array}{l}\text { Stroke risk in the intervention group was } 23 \\
\text { (20 to } 26 \text { ) per } 1000 \text { participants }\end{array}$ & $\begin{array}{l}\text { OR } 0.73(0.58 \\
\text { to } 0.91)\end{array}$ & $\begin{array}{l}-\mathbf{0 . 0 0}(-0.01 \\
\text { to } 0.00)\end{array}$ & $\begin{array}{l}22,835 \\
(8 \mathrm{RCTs})\end{array}$ & $\begin{array}{l}\oplus \oplus \oplus \oplus \\
\text { High }\end{array}$ & $\begin{array}{l}<1 \text { is benefi- } \\
\text { cial }\end{array}$ \\
\hline
\end{tabular}

CI: confidence interval; CVD: cardiovascular disease; LDL-C: low-density lipoprotein cholesterol; OR: odds ratio; RCT: randomised controlled trial; RD: risk difference. 
GRADE Working Group grades of evidence

High certainty: we are very confident that the true effect lies close to the estimate of effect.

Moderate certainty: we are moderately confident in the effect estimate: the true effect is likely to be close to the estimate of effect but may be substantially different

Low certainty: our confidence in the effect estimate is limited: the true effect may be substantially different from the estimate of effect.

Very low certainty: we have very little confidence in the effect estimate: the true effect is likely to be substantially different from the estimate of effect.

\section{Summary of findings 2. Evolocumab compared with placebo}

\section{Evolocumab compared with placebo}

Patient or population: people at high risk of CVD (history of CVD or high LDL-C despite treatment)

Setting: outpatient care settings

Intervention: evolocumab PCSK9 monoclonal antibodies

Comparison: placebo

\begin{tabular}{|c|c|c|c|c|c|c|c|}
\hline \multirow[t]{2}{*}{ Outcomes } & \multicolumn{2}{|c|}{ Illustrative comparative risk $(95 \% \mathrm{Cl})$} & \multirow{2}{*}{$\begin{array}{l}\text { Relative ef- } \\
\text { fect }(95 \% \mathrm{CI})\end{array}$} & \multirow[t]{2}{*}{ RD $(95 \% \mathrm{CI})$} & \multirow{2}{*}{$\begin{array}{l}\text { Number of } \\
\text { participants } \\
\text { (studies) }\end{array}$} & \multirow{2}{*}{$\begin{array}{l}\text { Certainty of } \\
\text { the evidence } \\
\text { (GRADE) }\end{array}$} & \multirow[t]{2}{*}{ Comments } \\
\hline & Assumed risk & Corresponding risk using PCSK9 inhibition & & & & & \\
\hline $\begin{array}{l}\text { CVD } \\
\text { Follow-up: } \\
6-36 \\
\text { months }\end{array}$ & $\begin{array}{l}\text { CVD risk was } 229 \\
\text { per } 1000 \text { partici- } \\
\text { pants }\end{array}$ & $\begin{array}{l}\text { CVD risk in the intervention group was } 213 \text { ( } 206 \\
\text { lower to } 220 \text { lower) per } 1000 \text { participants }\end{array}$ & $\begin{array}{l}\text { OR } 0.84(0.78 \\
\text { to } 0.91)\end{array}$ & $\begin{array}{l}-\mathbf{0 . 0 2}(-0.02 \\
\text { to }-0.01)\end{array}$ & $\begin{array}{l}29,432 \\
\text { (3 RCTs) }\end{array}$ & $\begin{array}{l}\oplus \oplus \oplus \oplus \\
\text { High }\end{array}$ & $\begin{array}{l}<1 \text { is benefi- } \\
\text { cial }\end{array}$ \\
\hline $\begin{array}{l}\text { Myocar- } \\
\text { dial in- } \\
\text { farction } \\
\text { Follow-up: } \\
6-36 \\
\text { months }\end{array}$ & $\begin{array}{l}\text { Myocardial infarc- } \\
\text { tion risk was } 143 \\
\text { per } 1000 \text { partici- } \\
\text { pants }\end{array}$ & $\begin{array}{l}\text { Myocardial infarction risk in the intervention } \\
\text { group was } 131(127 \text { to } 135) \text { per } 1000 \text { partici- } \\
\text { pants }\end{array}$ & $\begin{array}{l}\text { OR } 0.72(0.64 \\
\text { to } 0.82)\end{array}$ & $\begin{array}{l}-\mathbf{0 . 0 1}(-0.02 \\
\text { to }-0.01)\end{array}$ & $\begin{array}{l}29,432 \\
\text { (3 RCTs) }\end{array}$ & $\begin{array}{l}\oplus \oplus \oplus \oplus \\
\text { High }\end{array}$ & $\begin{array}{l}<1 \text { is benefi- } \\
\text { cial }\end{array}$ \\
\hline $\begin{array}{l}\text { Any } \\
\text { stroke }\end{array}$ & $\begin{array}{l}\text { Stroke risk was } 27 \\
\text { per } 1000 \text { partici- } \\
\text { pants }\end{array}$ & $\begin{array}{l}\text { Stroke risk in the intervention group was } 23 \text { ( } 20 \\
\text { to } 26 \text { ) per } 1000 \text { participants }\end{array}$ & $\begin{array}{l}\text { OR } 0.79(0.65 \\
\text { to } 0.94)\end{array}$ & $\begin{array}{l}-0.00(-0.01 \\
\text { to }-0.00)\end{array}$ & $\begin{array}{l}28,531 \\
(2 \mathrm{RCTS})\end{array}$ & $\begin{array}{l}\oplus \oplus \oplus \oplus \\
\text { High }\end{array}$ & $\begin{array}{l}<1 \text { is benefi- } \\
\text { cial }\end{array}$ \\
\hline
\end{tabular}




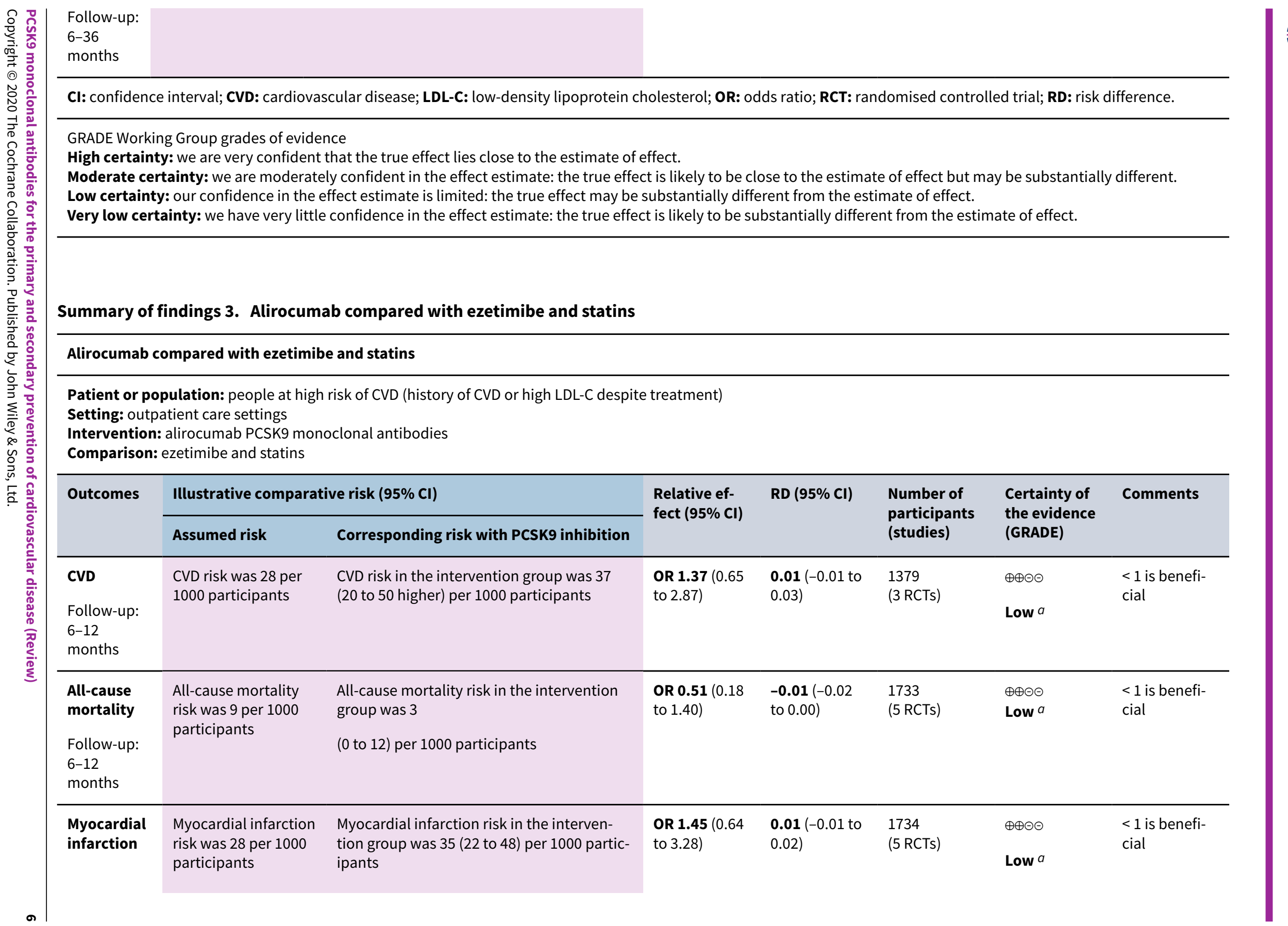




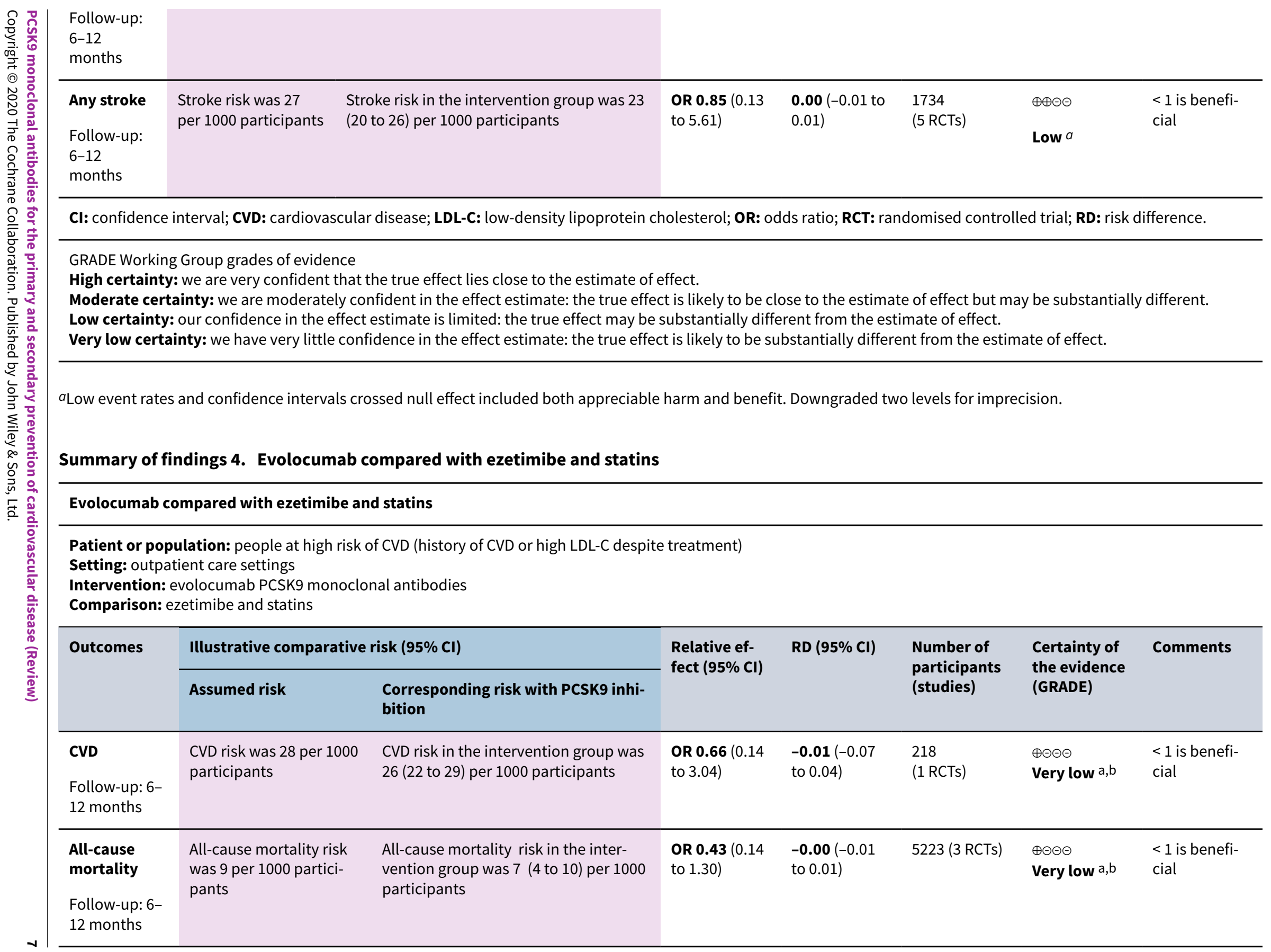




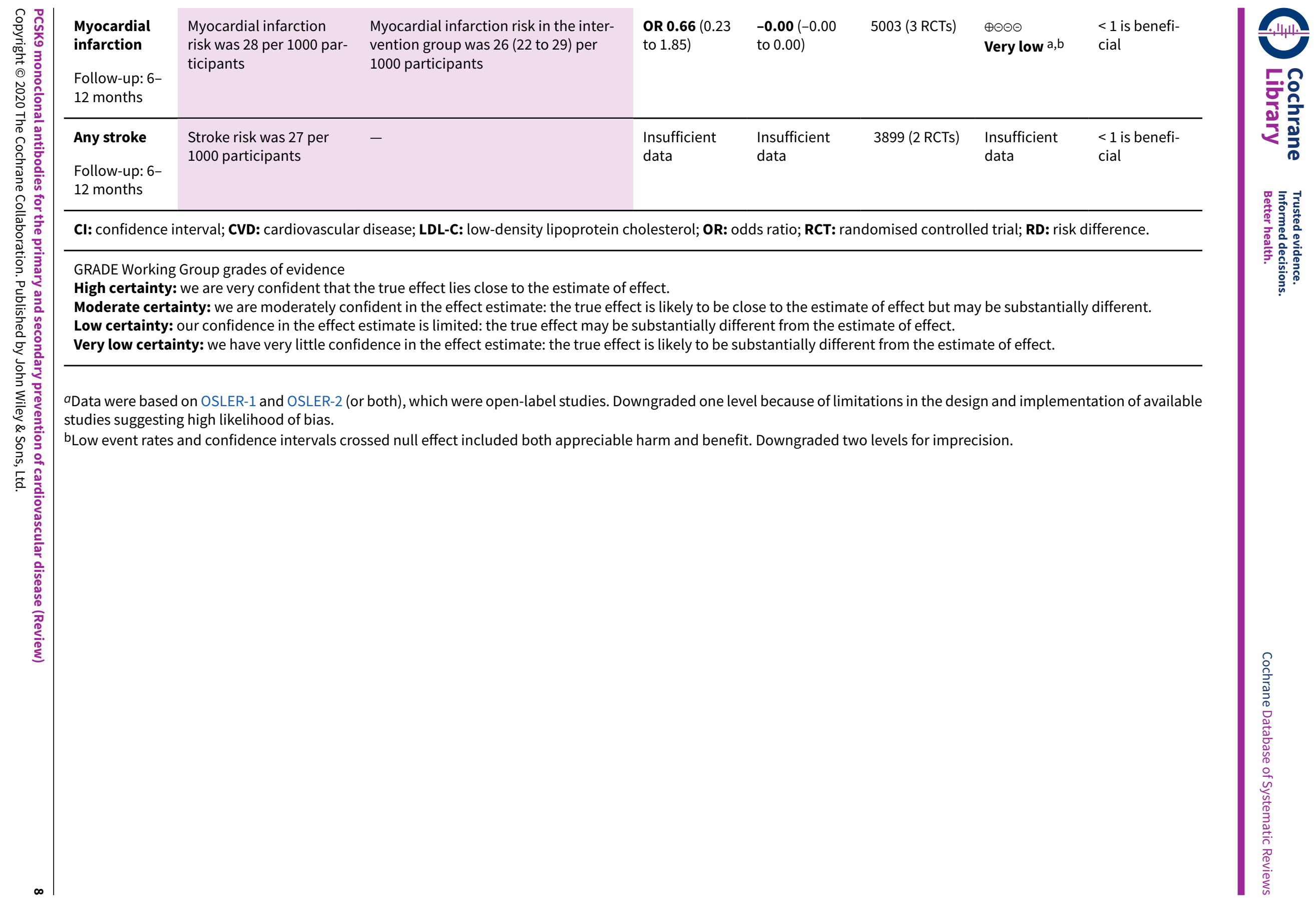




\section{B A C K G R O U N D}

\section{Description of the condition}

Cardiovascular disease event (CVD; coronary heart disease (CHD) and stroke) affects 85 million subjects across Europe (Willer 2013). Patients receive long-term medications for primary and secondary prevention (at a combined direct and indirect cost of $€ 210$ billion each year; Willer 2013). This burden is especially high in people with familial hypercholesterolaemia (FH) who have a loss of function mutation, which affects 1 in 250 individuals of European descent (Benn 2012; Knowles 2014; Nordestgaard 2013). These mutations prevent removal of circulating low-density lipoprotein cholesterol (LDL-C), which is one of the most important modifiable risk factors for CVD (Grundy 2004), both in people with $\mathrm{FH}$ and in the general population. Autosomal-dominant $\mathrm{FH}$ is caused by heterozygous mutations in the low-density lipoprotein receptor (LDLR) (Sudhof 1985), apolipoprotein B (APOB) - the major constituent apoprotein of LDL-C (Garcia 2001; Innerarity 1987; Nordestgaard 2013), or the gene for proprotein convertase subtilisin/kexin type 9 (Abifadel 2003). A rare autosomal-recessive form of $\mathrm{FH}$ is caused by mutations in the gene for the low-density lipoprotein receptor adaptor protein 1 (LDRRAP1). People with $\mathrm{FH}$ have higher risk of premature coronary heart disease (CHD) that can be reduced with statin treatment. Polygenic elevation in LDL-C concentration, which is associated with higher risk of CHD, is caused by additive effects of common, largely independently inherited polymorphisms located in more than 50 loci throughout the genome (Willer 2013).

\section{Description of the intervention}

Interventions of confirmed efficacy in reducing cardiovascular events through lowering of LDL-C include statin drugs targeting 3-hydroxy-3-methyl-glutaryl-CoA (HMG-CoA) reductase and ezetimibe targeting the Niemann-Pick C1-like 1 intestinal cholesterol transporter protein (Cannon 2015; CTT 2005a; CTT 2005b; CTT 2012). Cardiovascular risk is reduced but not abolished among people receiving these medications, suggesting that additional $L D L-C$ reduction via alternative pathways may result in further reduction in CVD events, especially among people who have an inadequate response to, or are intolerant of, statins or ezetimibe (Mancini 2011; Marks 2003).

A new pharmacological target for further reduction of LDL-C is the proprotein convertase subtilisin/kexin type 9 (PCSK9) enzyme. Two monoclonal antibodies (mAbs) against the PCSK9 enzyme (PCSK9 inhibitors), alirocumab and evolocumab, have been approved for high-risk people; both are administered subcutaneously.

\section{How the intervention might work}

PCSK9 is synthesised and secreted by hepatocytes and binds to the LDLR on the hepatocyte surface, promoting internalisation and degradation. Reduction in surface LDLR reduces uptake of LDL particles and increases LDL-C concentration in the blood (Cohen 2005; Cohen 2006). Therefore, inhibitors of PCSK9 are expected to lower LDL-C. Moreover, inhibition of PCSK9 may further enhance the lipid-lowering effects of statins, which are thought to be limited by a statin-induced increase in PCSK9 expression (Catapano 2013).

PCSK9 inhibitors bind to the PCSK9 enzyme with high affinity, disrupting its ability to bind with LDLR. By preventing PCSK9 from binding to LDLR, inhibitors against PCSK9 maintain surface LDLR expression with the aim of reducing LDL-C serum concentration. This is supported by the finding that variations in the PCSK9 gene are associated with long-term elevations in LDL-C and higher risk of CHD (Benn 2010; Chasman 2012). Alternatively, loss of function mutations in PCSK9 that lower LDL-C levels have also been associated with decreased CHD risk (Cohen 2006). Taken together, these gain- and loss-of-function PCSK9 genetic studies strongly validated PCSK9 as an efficacious target for prevention of CVD.

\section{Why it is important to do this review}

Statins are widely prescribed to reduce LDL-C levels and CVD risk in people at increased risk. People taking statins reduce their risk of CVD by around $20 \%$ to $25 \%$ for every $1 \mathrm{mmol} / \mathrm{L}$ decrease in LDL-C (CTT 2005a; CTT 2012), which may be further reduced by taking ezetimibe (Cannon 2015). Given the strong and positive associations, without clear threshold, between LDL-C and CVD as described in prospective studies (CTT 2005a; CTT 2012), it is expected that further reduction in LDL-C may lead to further prevention of CVD events. This could be especially important for people unable to tolerate statins, people with very high levels of LDL-C, and people at high cardiovascular risk. Large sample size phase 3 randomised controlled trials (RCTs) have shown that alirocumab and evolocumab both reduce CVD risk when prescribed in addition to statins (FOURIER; ODYSSEY OUTCOMES); however, information on the medium-term to long-term safety and efficacy of these drugs has not yet been reviewed. Furthermore, PCSK9 mAb effectiveness and safety compared to therapies such as statins or ezetimibe are unclear.

Statin prescriptions seem to increase the risk of the following unintended (safety) endpoints: type 2 diabetes mellitus (T2DM), weight gain (Sattar 2010; Swerdlow 2014), and rarely liver inflammation, and myositis (Collins 2016). It is uncertain if reducing LDL-C via a different mechanism might be associated with the same or a different set of adverse events. Furthermore, with recent Food and Drug Administration (FDA) and European Medicines Agency (EMA) approvals of alirocumab (Praluent) and evolocumab (Repatha), these drugs have become available to (selected) patients, and (remaining) questions on long-term efficacy and safety have become increasingly important to answer. Specifically, the EMA has approved Praluent and Repatha for people with primary hypercholesterolaemia, and the FDA has approved both drugs for people with heterozygous $\mathrm{FH}$ or a history of clinical atherosclerotic CVD. These recommendations have found their way into the 2016 European Society of Cardiology (ESC)/European Atherosclerosis Society (EAS) Guidelines for the Management of Dyslipidaemias, which recommend consideration of a PCSK9 inhibitor for pharmacological treatment of hypercholesterolaemia "in patients at very high-risk, with persistent high LDL-C despite treatment with maximal tolerated statin dose, in combination with ezetimibe or in patients with statin intolerance". The same guidelines recommend that "treatment with a PCSK9 antibody should be considered in FH patients with CVD or at very high-risk for CHD" (Catapano 2016). Pfizer discontinued the development of bococizumab, citing lack of long-term efficacy due to increased immunogenicity over time (Pfizer 2017). A number of large sample size PCSK9 mAb trials have been published since the previous version of the review, as such we sought to update the original results. 


\section{O B JECTIVES}

\section{Primary}

To quantify the effects of PCSK9 inhibitors on CVD, all-cause mortality myocardial infarction, and stroke, compared to placebo or active treatment(s) for primary and secondary prevention.

\section{Secondary}

To quantify the safety of PCSK9 inhibitors, with specific focus on the incidence of influenza, hypertension, type 2 diabetes, and cancer, compared to placebo or active treatment(s) for primary and secondary prevention.

\section{METHODS}

\section{Criteria for considering studies for this review}

\section{Types of studies}

We included parallel-group and factorial RCTs with follow-up of at least 24 weeks. Cluster RCTs, cross-over trials, and non-randomised studies were ineligible for this review, and we excluded them during title and abstract screening; we noted a single cross-over trial that we have excluded for this reason (Nissen 2016). RCTs were eligible if they were reported as full-text articles or were published as abstracts, or if they were available only as unpublished data.

\section{Types of participants}

RCTs were eligible if they included adults 18 years of age or older, with or without a history of CVD. Participants could have had normal lipid levels or hypercholesterolaemia. We applied no restriction on comorbidities.

\section{Types of interventions}

We included trials if they randomised participants to the PCSK9 inhibitors alirocumab or evolocumab, and to placebo, or active treatments such as statins, ezetimibe, or a combination of these.

\section{Types of outcome measures}

This updated review no longer explored the effects of PCSK9 mAb with (lipid) biomarkers, large sample size trials have shown a persistent decreasing effect on these intermediate outcomes, to an extent that there is little uncertainty left on these effects (FOURIER; ODYSSEY Long Term; ODYSSEY OUTCOMES).

Reporting one or more of the outcomes listed here in the trial was not an inclusion criterion for the review. Where a published report did not report one of these outcomes, we accessed the trial protocol and contacted the trial authors to ascertain whether the outcomes were measured but not reported. Relevant trials which measured these outcomes but did not report the data at all, or not in a usable format, were included in the review as part of the narrative.

\section{Primary outcomes}

- Composite endpoint of CVD, defined as urgent coronary revascularisation, unstable angina pectoris, non-fatal and fatal myocardial infarction (MI), non-fatal and fatal stroke, and CHD death.

- All-cause mortality.

- MI.
- Stroke.

\section{Secondary outcomes}

- Adverse events, specifically:

* influenza;

* T2DM;

* cancer;

* hypertension.

\section{Search methods for identification of studies}

\section{Electronic searches}

We identified trials through systematic searches of the following databases (Lefebvre 2011):

- Cochrane Central Register of Controlled Trials (CENTRAL) in the Cochrane Library (2019, Issue 11);

- MEDLINE and Epub Ahead of Print, In-Process \& Other NonIndexed Citations and Daily (Ovid, 1946 to 5 December 2019);

- Embase (Ovid, 1980 to 2 December 2019);

- Web of Science Core Collection (Clarivate Analytics, 1900 to 2 December 2019).

See Appendix 1 for the search strategies used. We applied the sensitivity-maximising version of the Cochrane RCT filter to MEDLINE and adaptations of it to Embase and Web of Science (Lefebvre 2011). We limited searches to records from 2005, as PCSK9 was discovered as a potential target in 2003 (Farnier 2014; Seidah 2003), hence we excluded papers published before 2005 . We imposed no language restrictions.

Additionally, we searched ClinicalTrials.gov (www.ClinicalTrials.gov) and the World Health Organization (WHO) International Clinical Trials Registry Platform (ICTRP) Search Portal (apps.who.int/trialsearch/) for relevant RCTs on 20 August 2020.

\section{Searching other resources}

We searched the following websites for unpublished studies on 20 August 2020:

- FDA (www.fda.gov/)

- Pharmaceutical company websites (Regeneron www.regeneron.com/; Sanofi - en.sanofi.com/)

- ProQuest dissertations and theses (PQDT; www.proquest.com/ products-services/pqdt.html).

Additionally, we screened reference lists of included studies for relevant RCTs.

\section{Data collection and analysis}

\section{Selection of studies}

Two review authors (AFS and JPLC) independently screened search results by title and abstract, and subsequently the full text, for potentially relevant studies. A third review author (JPC) resolved disagreements. We distilled multiple reports on a single RCT into a single entry. We provided a PRISMA flow diagram, and details of studies excluded after full-text assessment (see Characteristics of excluded studies table). 


\section{Data extraction and management}

Two review authors (AFS and JPLC) independently extracted data and resolved differences by returning to the original publication and, if needed, by consulting a third review author (JPC). When appropriate, we extracted data on numbers of events versus no events, means, standard deviations, crude point estimates, or standard error estimates. When reported, we extracted results from an intention-to-treat (ITT) analysis. When available, we used the study protocol, appendices, and design papers as additional sources of information.

\section{Assessment of risk of bias in included studies}

We assessed risk of bias using the Cochrane 'Risk of bias' tool based on the following items (Higgins 2011).

- Random sequence generation (selection bias).

- Allocation (selection bias).

- Blinding of participants and personnel (performance bias).

- Blinding of outcome assessment (detection bias).

- Incomplete outcome data (attrition bias).

- Selective reporting (reporting bias).

- Other potential sources of bias.

We graded individual items as having 'low', 'unclear', or 'high' risk of bias.

\section{Assessment of bias in conducting the systematic review}

We conducted this Cochrane Review according to the published protocol (Schmidt 2015), and reported deviations from it in the Differences between protocol and review section.

\section{Measures of treatment effect}

We reported treatment effects as odds ratios (ORs) and risk differences (RDs) (Newcombe 2014), 95\% with confidence intervals (Cls) calculated using the Wald method. Estimates are presented for the effect of alirocumab and evolocumab compared to placebo or active treatment (including statins and ezetimibe or other pharmacological interventions that lower LDL-C), resulting in four effect estimates for any one outcome.

\section{Unit of analysis issues}

The unit of analysis was the participant. This Cochrane Review focused exclusively on parallel-group designed RCTs, hence we had no unit of analysis issues.

\section{Dealing with missing data}

We contacted trial authors to request missing data.

\section{Assessment of heterogeneity}

We measured between-study heterogeneity by using the $I^{2}$ statistic with a one-sided $\mathrm{Cl}$ (with a $\mathrm{z}$ value of -1.96 ) and tested it using a $\mathrm{Q}$ test.

\section{Assessment of reporting biases}

We explored reporting bias using funnel plots for outcomes with 10 or more studies.

\section{Data synthesis}

Before meta-analysing results, we grouped trials comparing alirocumab or evolocumab to placebo or active treatment. Trials comparing PCSK9 mAbs against statins only were unavailable. OR study-specific estimates were combined using Review Manager's inverse variance method for fixed-effect meta-analysis (Review Manager 2014). Similarly, we calculated fixed-effect RD estimates using generalised linear models with a random intercept for study (Bradburn 2007; Sweeting 2004).

In the case of multiple treatment or comparator arms, we pooled estimates across arms to facilitate a comparison between inhibitors and comparison therapy. Alternatively, we could have compared results from a single intervention arm versus multiple comparator groups (or vice versa), but this would have resulted in correlated effect estimates with erroneously small $P$ values (i.e. increased type 1 errors)

\section{Subgroup analysis and investigation of heterogeneity}

Subgroup analysis and meta-regression of the LDL-C estimates were employed in a previous version of this review (Schmidt 2017), finding clinically insignificant heterogeneity in LDL-C effect. Given the availability of large sample size RCTs, finding limited longitudinal variation in LDL-C (and other biomarkers), we chose to focus on clinical endpoints data in the current update and readers interested in the biomarker evidence are referred to the previous publication.

Due to the unavailability of subgroup specific reports, these analyses could not be performed for clinical endpoints. In the previous version of the review, we did contact the trialists requesting additional results, which were never shared.

\section{Sensitivity analysis}

We evaluated the effect of PCSK9 mAbs on the individual components of major CVD, specifically any stroke and MI.

\section{Summary of findings and assessment of the certainty of the evidence}

We created 'Summary of findings' tables (using the GRADE approach to assess the certainty of evidence; Grade Working Group 2004) for each comparison separately, and (based on the protocol) for CVD, mortality outcomes, MI, and any stroke. We calculated risk under the intervention using RDs; we included odds ratios in the table but did not use them to calculate (reduced) risk under treatment. The absolute risk of disease, without PCSK9 treatment, was estimated by dividing the total number of events in the placebo arm by the total number of participants allocated to placebo (per compound, summed across trials).

\section{RES U L T S}

\section{Description of studies}

We searched to include randomiaed controlled trials.

\section{Results of the search}

The search yielded 1873 hits, which we supplemented by 15 additional records obtained by cross-referencing trial registry sites and other sources (see Figure 1 for a flow diagram). After screening titles and abstracts, we retrieved 68 full-text articles and excluded 
36 of these. We included 34 references describing 24 studies. Most studies had multiple publications (e.g. conference abstracts) that we distilled into a single entry. The alirocumab trial, focussing on plaque phenotypes, did not report on any outcomes relevant for the present review (Sugizaki 2019). For the ODYSSEY trials, we extracted additional information from an FDA report (FDA 2015). 
Figure 1. Study flow diagram. RCT: randomised controlled trial.

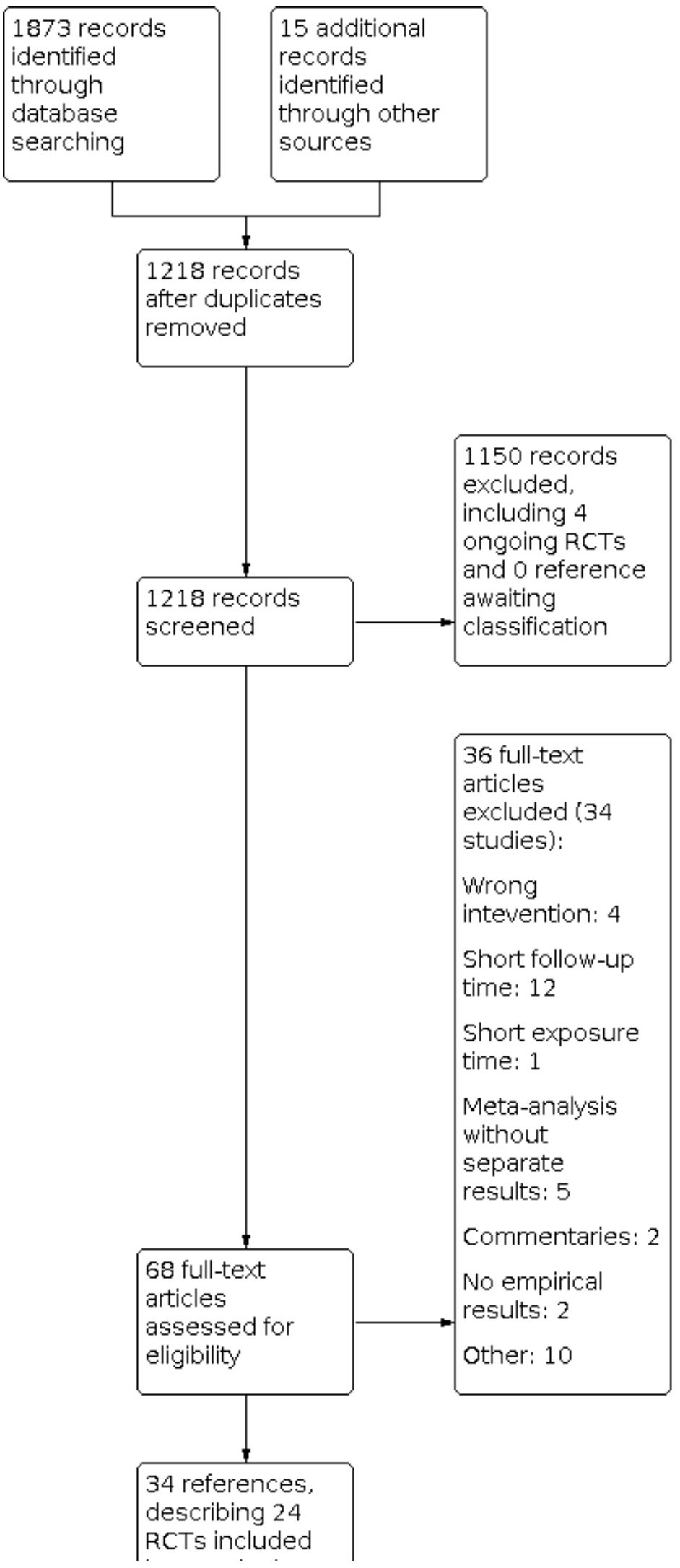


Figure 1. (Continued)

$$
\begin{aligned}
& \text { uescilun Iy } \angle 4 \\
& \text { RCTs included } \\
& \text { in quantitative } \\
& \text { synthesis } \\
& \text { (meta-analysis) }
\end{aligned}
$$

Compared to the 2017 version of the review, the terminated bococizumab (three) and RG7652 (one) trials were removed. We included seven additional studies evaluating alirocumab or evolocumab.

\section{Included studies}

\section{PCSK9 inhibitors; settings and participants}

Investigators collected a combined sample of 60,997 participants, with 26,538 randomised to alirocumab (in 18 trials), and 34,435 to evolocumab (six trials). Out of the unique participants, 17,682 were women (7721 (29\%) alirocumab participants and 9961 (29\%) evolocumab participants for whom gender was reported), 4590 had no history of CVD ( $10 \%$ of the alirocumab participants and $7 \%$ of the evolocumab participants), 1879 had $\mathrm{FH}$ (22\% of the alirocumab participants and $38 \%$ of the evolocumab participants), 18,908 had a T2DM diagnosis at baseline $32 \%$ in alirocumab and $34 \%$ evolocumab trials; out of participants with reported T2DM status). We noted that the three $\mathrm{FH}$ studies focused exclusively on participants with $\mathrm{FH}$ (self-identified). Caucasians were the predominant ethnic group included in these studies $(50,804$ participants). All trials included participants treated in outpatient care settings.

\section{Comparison group}

All, but one study (Sugizaki 2019), were industry-sponsored, multicentre trials. Twelve alirocumab trials were placebo controlled (ODYSSEY CHOICE II; ODYSSEY CHOICE I; ODYSSEY COMBO I; ODYSSEY DM-DYSLIPIDEMIA; ODYSSEY FH I; ODYSSEY FH II; ODYSSEY HIGH FH; ODYSSEY JAPAN; ODYSSEY Long Term; ODYSSEY DMINSULIN; ODYSSEY KT; ODYSSEY OUTCOMES), on the background of lipid-lowering treatments such as statin or ezetimibe therapies. Six studies randomised participants to either ezetimibe only, or to ezetimibe with statins combined (ODYSSEY ALTERNATIVE; ODYSSEY COMBO II; ODYSSEY MONO; ODYSSEY OPTIONS I; ODYSSEY OPTIONS II; Sugizaki 2019). For evolocumab trials, three (Descartes; FOURIER; GLAGOV) studies were placebo controlled, and three
(GLAGOV; OSLER-1; OSLER-2) randomised subjects to active treatments including statins and/or ezetimibe.

Note that the ODYSSEY OPTIONS I and OPTIONS II trials compared alirocumab with ezetimibe and atorvastatin, atorvastatin, or rosuvastatin. As described in the Data synthesis section, to prevent erroneously small $P$ values (due to use of the same alirocumab arm twice), we combined multiple arms of comparison groups and estimated effects of alirocumab versus ezetimibe and statin.

Researchers administered PCSK9 inhibitors every two weeks, every four weeks, or every eight weeks; for the sake of comparison, we calculated the two weeks' equivalence dosage (see Characteristics of included studies table), which ranged from $50 \mathrm{mg}$ to $210 \mathrm{mg}$ every two weeks. In most studies (except Descartes; ODYSSEY FH II; ODYSSEY HIGH FH; ODYSSEY Long Term; OSLER-1), participants received different dosages of PCSK9, often depending on a predefined uptitration criterion such as LDL-C reduction or history of CVD.

\section{Excluded studies}

We excluded 34 trials, predominantly owing to follow-up time less than 24 weeks (see main objectives), or because trials described a meta-analysis while providing little to no detail on individual studies (which were already included separately) (Characteristics of excluded studies table).

\section{Ongoing studies}

We identified four ongoing trials that may fit our inclusion criteria and may be included at a later review update (Characteristics of ongoing studies table).

\section{Risk of bias in included studies}

We have provided, a per-study, risk of bias assessment with rationale in the Characteristics of included studies table. All studies described used a randomised trial design; we have discussed risk of bias in the following sections and have summarised this information in Figure 2 and Figure 3. 
Figure 2. Risk of bias graph: review authors' judgements about each risk of bias item presented as percentages across all included studies.

Random sequence generation (selection bias)

Allocation concealment (selection bias)

Blinding of participants and personnel (performance bias): All outcomes

Blinding of outcome assessment (detection bias): All outcomes Incomplete outcome data (attrition bias): All outcomes

Selective reporting (reporting bias)

Other bias
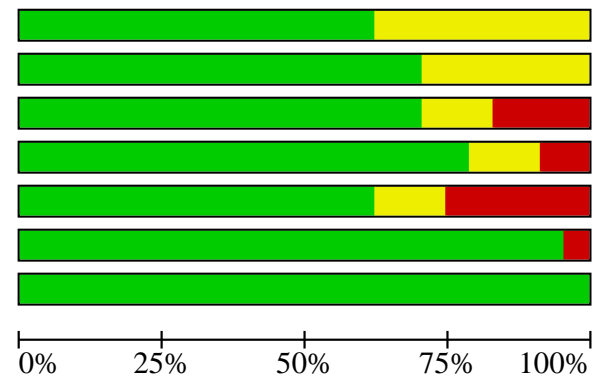

$\square$ Low risk of bias $\square$ Unclear risk of bias

High risk of bias 
Figure 3. Risk of bias summary: review authors' judgements about each risk of bias item for each included study.

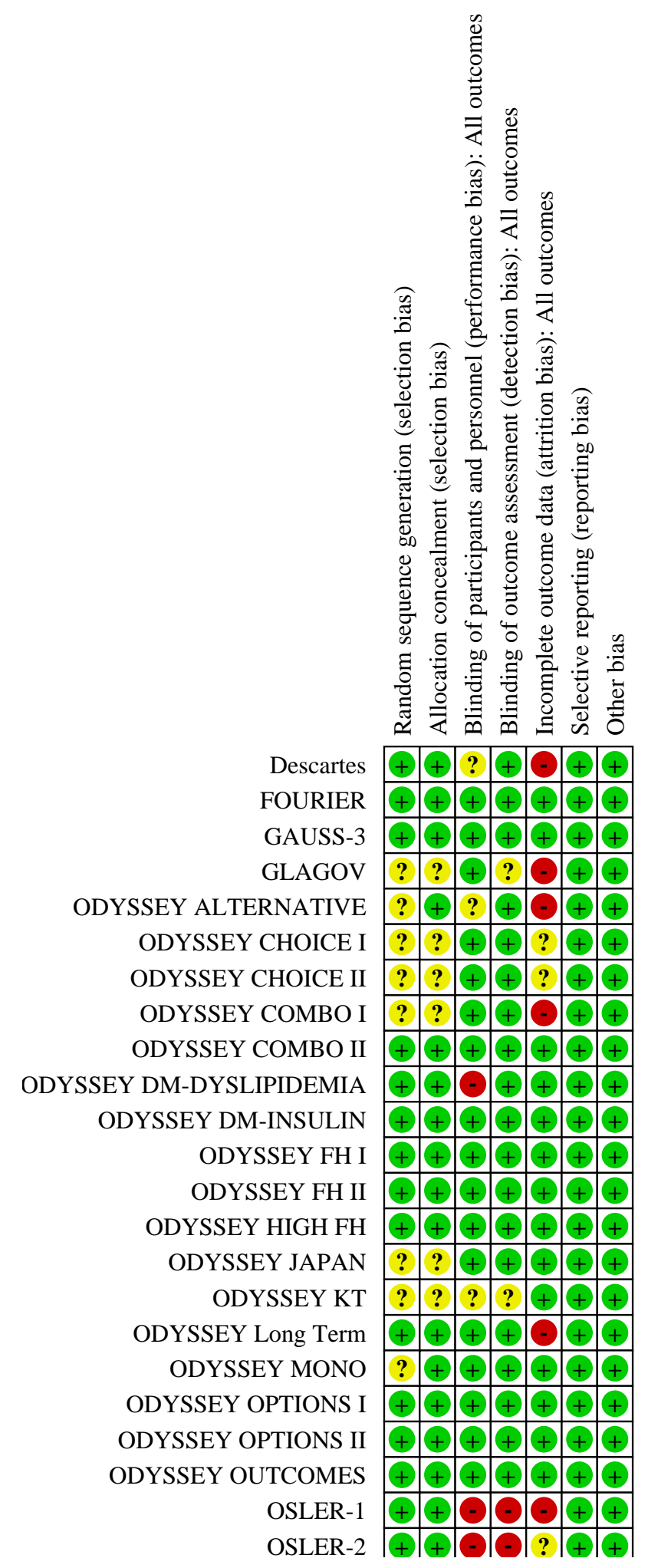


Figure 3. (Continued)

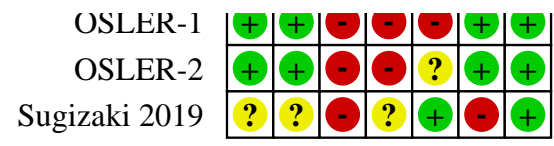

\section{Allocation}

Eight trials provided insufficient detail on how randomisation was achieved (unclear risk of bias) (GLAGOV; ODYSSEY ALTERNATIVE; ODYSSEY CHOICE I; ODYSSEY CHOICE II; ODYSSEY COMBO I; ODYSSEY JAPAN; ODYSSEY KT; ODYSSEY MONO; Sugizaki 2019). The remaining studies typically used a voice-based or Internet-based centralised response system, and we perceived them to have low risk of bias.

Most RCTs ensured allocation concealment by using centralised allocation and in some cases permuted blocks. Six RCTs did not sufficiently report on this item, and we perceived them as having unclear risk of bias (GLAGOV; ODYSSEY CHOICE I; ODYSSEY CHOICE II; ODYSSEY COMBO I; ODYSSEY JAPAN; ODYSSEY KT; Sugizaki 2019).

\section{Blinding}

Owing to the open-label design, the ODYSSEY DMDYSLIPIDEMIA; OSLER-1; OSLER-2; and Sugizaki 2019 studies were at high risk of performance bias and detection bias. The open-label design makes it conceivable that knowledge of allocated drugs could influence participant behaviour, and similar might influence physician diagnoses.

The following trials were judged to be at an unclear risk of performance or detection bias due to insufficient reporting details: Descartes; GLAGOV; ODYSSEY ALTERNATIVE; ODYSSEY KT.

\section{Incomplete outcome data}

Loss due to follow-up (attrition bias) was typically low (arbitrarily defined as less than 5\%), except in Descartes; GLAGOV; ODYSSEY ALTERNATIVE; ODYSSEY COMBO I; ODYSSEY Long Term; OSLER-1; and OSLER-2. Most studies used advanced analytics, such as mixedeffects models or (multiple) imputations, to ameliorate loss due to follow-up (even if this was minor) and to ensure the ITT analysis. However, information on both performance of these methods and appropriateness of assumptions underlying these methods was missing

Three trials (ODYSSEY CHOICE I; ODYSSEY CHOICE I; OSLER-2) provided insufficient information to evaluate attrition bias and were evaluated to be at an unclear risk of bias.

\section{Selective reporting}

We compared endpoints described in study protocols and on ClinicalTrials.gov versus endpoints reported in the primary publication, and generally found good agreement. Despite moderate 36-week follow-up, the non-industry sponsored Sugizaki 2019 did not report on the incidence of CVD outcomes and was at high risk of reporting bias (reported only as abstract).

\section{Other potential sources of bias}

We identified no other potential sources of bias.

\section{Effects of interventions}

See: Summary of findings 1 Alirocumab compared with placebo; Summary of findings 2 Evolocumab compared with placebo; Summary of findings 3 Alirocumab compared with ezetimibe and statins; Summary of findings 4 Evolocumab compared with ezetimibe and statins

See 'Summary of findings' tables for the following.

- Alirocumab PCSK9 mAb versus placebo (Summary of findings 1).

- Evolocumab PCSK9 mAb versus placebo (Summary of findings 2).

- Alirocumab PCSK9 mAb versus active treatment (Summary of findings 3).

- Evolocumab PCSK9 mAb versus active treatment (Summary of findings 4).

\section{Alirocumab PCSK9 monoclonal antibody compared with placebo}

Comparing alirocumab with placebo, the intended effects were as follows: RD $-2 \%$, OR 0.87 (95\% Cl 0.80 to $0.94 ; 10$ studies, 23,868 participants; high-certainty evidence; Analysis 1.1) for any CVD event; RD -1\%; OR 0.83 (95\% Cl 0.72 to $0.96 ; 12$ studies, 24,797 participants; high-certainty evidence; Analysis 1.2) for all-cause mortality; RD -2\%, OR 0.86 (95\% Cl 0.79 to 0.94 ; 9 studies, 23,352 participants; high-certainty evidence; Analysis 1.3) for any MI; and RD less than $-1 \%$, OR 0.73 (95\% Cl 0.58 to $0.91 ; 8$ studies, 22,835 participants; high-certainty evidence; Analysis 1.4) for any stroke.

Treatment effect estimates of unintended effects were as follows: RD $1 \%$, OR 1.09 (95\% Cl 0.83 to 1.42 ) for influenza; RD less than $-1 \%$, OR 0.96 (95\% $\mathrm{Cl} 0.86$ to 1.07 ) for T2DM; RD less than $-1 \%$, OR 0.88 ( $95 \% \mathrm{Cl} 0.61$ to 1.26 ) for any cancer diagnosis; and RD less than $-1 \%$, OR 0.92 ( $95 \% \mathrm{Cl} 0.72$ to 1.18 ) for hypertension. Evaluation of these treatment effect estimates on the RD scale revealed that the effect of PCSK9 inhibitors on the risk of an event was typically modest, with changes in risk often less than $1 \%$ (see Table 1 and Analysis 1.5; Analysis 1.6; Analysis 1.7; Analysis 1.8).

\section{Evolocumab PCSK9 monoclonal antibody compared with placebo}

Comparing evolocumab with placebo, the intended effects were as follows: RD $-2 \%$, OR 0.84 (95\% Cl 0.78 to $0.91 ; 3$ studies, 29,432 participants; high-certainty evidence; Analysis 2.1) for any CVD event; RD less than $1 \%$, OR $1.04(95 \% \mathrm{Cl} 0.91$ to $1.19 ; 3$ studies, 29,432 participants; high-certainty evidence; Analysis 2.2) for allcause mortality; RD $-1 \%$, OR 0.72 (95\% $\mathrm{Cl} 0.64$ to 0.82 ; 3 studies, 29,432 participants; high-certainty evidence; Analysis 2.3$)$ for any $\mathrm{MI}$; and RD less than $1 \%$, OR 0.79 (95\% $\mathrm{Cl} 0.65$ to $0.94 ; 2$ studies, 28,531 participants; high-certainty evidence; Analysis 2.4 ) for any stroke. 
Treatment effect estimates of unintended effects were as follows: RD 1\%, OR 1.21 (95\% Cl 0.69 to 2.11) for influenza; RD less than $-1 \%$, OR 1.05 ( $95 \% \mathrm{Cl} 0.94$ to 1.17) for T2DM; with an absence of information on hypertension and cancer diagnoses (see Table 2 and Analysis 2.5; Analysis 2.6).

\section{Alirocumab PCSK9 monoclonal antibody compared with active treatment}

Comparing alirocumab with active treatment, the intended effects were as follows: RD $1 \%$, OR 1.37 (95\% Cl 0.65 to $2.87 ; 3$ studies, 1379 participants; low-certainty evidence; Analysis 3.1) for any CVD event; RD $-1 \%$, OR $0.51(95 \% \mathrm{Cl} 0.18$ to $1.40 ; 5$ studies, 1733 participants; low-certainty evidence; Analysis 3.2) for all-cause mortality; RD 1\%, OR 1.45 (95\% Cl 0.64 to 3.28, 5 studies, 1734 participants; low-certainty evidence; Analysis 3.3) for any MI; and RD less than $-1 \%$, OR $0.85(95 \% \mathrm{Cl} 0.13$ to $5.61 ; 5$ studies, 1734 participants; low-certainty evidence; Analysis 3.4) for any stroke.

Treatment effect estimates of unintended effects were as follows: RD 1\%, OR 1.72 (95\% Cl 0.91 to 3.25) for influenza; RD $2 \%$, OR 0.28 ( $95 \% \mathrm{Cl} 0.05$ to 1.55 ) for T2DM; RD less than 1\%, OR 1.08 (95\% $\mathrm{Cl} 0.43$ to 2.69 ) for any cancer diagnosis; and RD less than $-1 \%$, OR 1.01 ( $95 \% \mathrm{Cl} 0.57$ to 1.79 ) for hypertension (see Table 3 and Analysis 3.5; Analysis 3.6; Analysis 3.7; Analysis 3.8).

\section{Evolocumab PCSK9 monoclonal antibody compared with active treatment}

Comparing evolocumab with active treatment, the intended effects were as follows: RD $-1 \%$, OR 0.66 (95\% $\mathrm{Cl} 0.14$ to $3.04 ; 1$ study; 218 participants; very low-certainty evidence; Analysis 4.1) for any CVD event; RD less than $-1 \%$, OR $0.43(95 \% \mathrm{Cl} 0.14$ to $1.30 ; 3$ studies, 5223 participants; very low-certainty evidence; Analysis 4.2) for allcause mortality; and RD less than $-1 \%$, OR 0.66 ( $95 \% \mathrm{Cl} 0.23$ to 1.85 ; 3 studies, 5003 participants; very low-certainty evidence; Analysis 4.3) for MI.

Treatment effect estimates of unintended effects were as follows: RD 1\%, OR 1.22 ( $95 \% \mathrm{Cl} 0.88$ to 1.70 ) for influenza; RD less than $1 \%$, OR 3.52 ( $95 \% \mathrm{Cl} 0.18$ to 68.33 ) for T2DM; and RD less than $1 \%$, OR 1.51 ( $95 \% \mathrm{Cl} 0.06$ to 37.04$)$ for hypertension, with an absence of information on any stroke and any cancer (Table 4 and Analysis 4.4; Analysis 4.5; Analysis 4.6).

\section{Outcomes and comparisons without data}

See respective sections for details on missing outcome data that were unavailable for some comparisons. Data on quality of life were unavailable for all studies. Finally, while we did present evidence for $\mathrm{MI}$ and any stroke, we did not have sufficient data to present further details on the individual components of any CVD such as angina pectoris, urgent revascularisation and so on. The alirocumab trial, focusing on plaque phenotypes, did not at present, report on any outcomes relevant for the present review (Sugizaki 2019).

\section{Reporting bias and small-study heterogeneity (funnel plots)}

Following the protocol funnel plots were generated for comparisons with 10 or more studies, that is for the alirocumab versus placebo effects on CVD and influenza: Figure 4; Figure 5. The CVD analysis shows a degree of asymmetry were small sample size studies with a protective effect (favouring alirocumab) appear absent. 
Figure 4. A funnel plot of the alirocumab versus placebo cardiovascular disease effects.

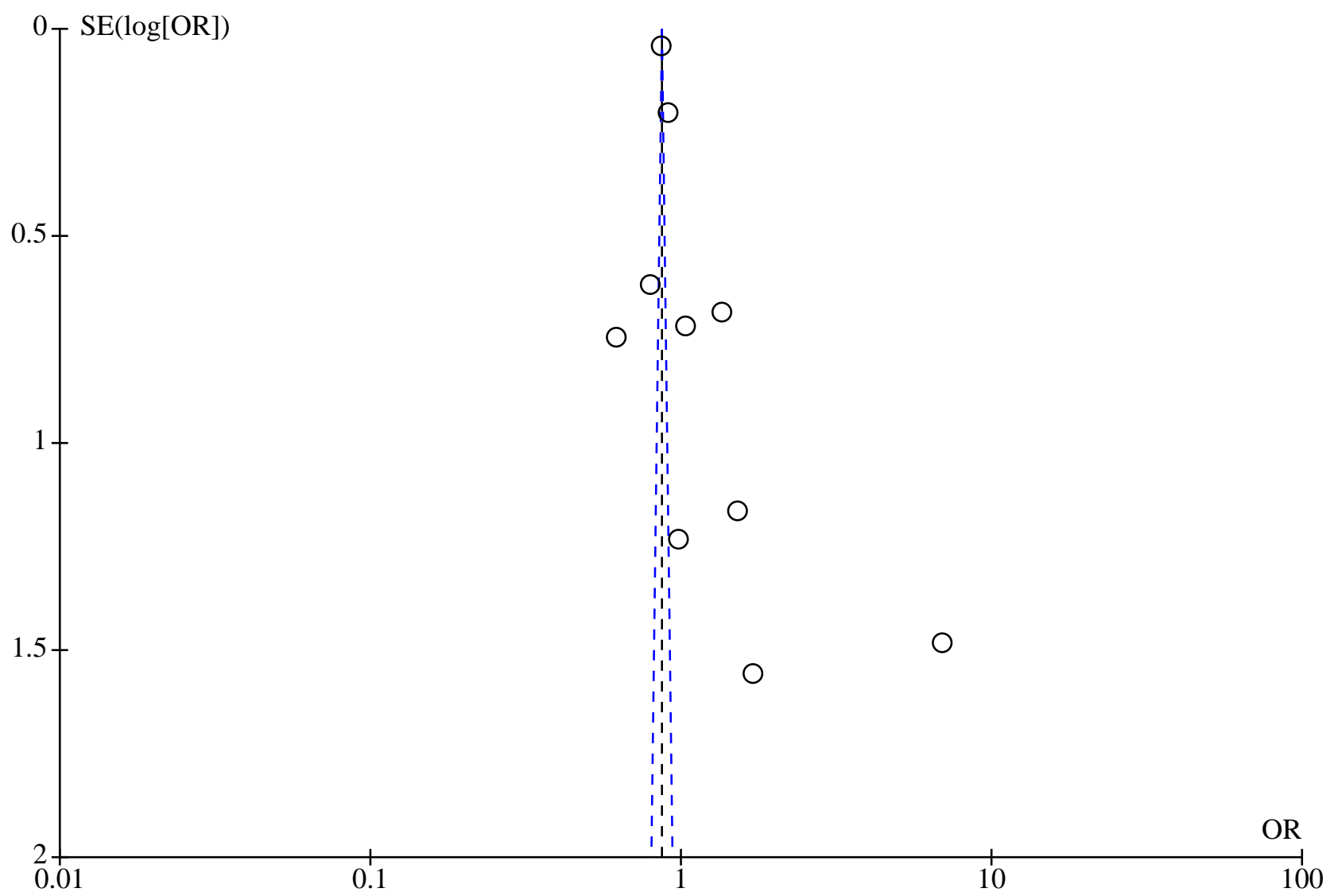


Figure 5. A funnel plot of the alirocumab versus placebo influenza effects.

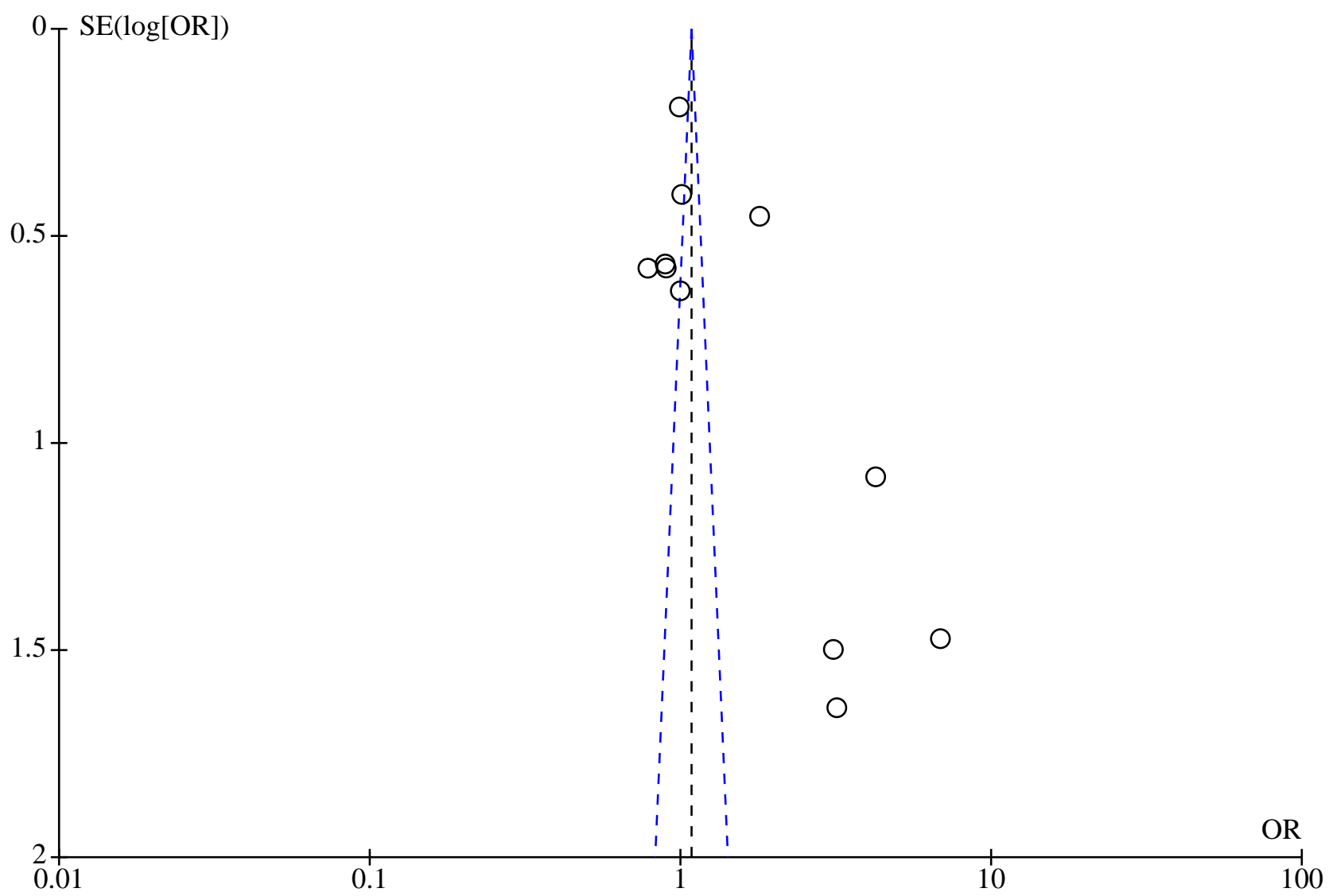

The currently available trials have all been conducted for market authorisation proposes, hence, it seems highly unlikely that any of such studies (given the FDA and EMA scrutiny), especially favouring a protective effect, would have remain unpublished. Instead, what is more likely, is that this seemingly asymmetry is a result of smaller studies selecting a different (possibly higher risk) patient population to increase power.

\section{DISCUSSION}

\section{Summary of main results}

In this systematic review and meta-analysis, we confirmed that PCSK9 inhibitors (alirocumab and evolocumab; mAbs) compared with placebo reduce the risk (high-certainty evidence) of CVD (as a composite), MI, stroke (combination of ischaemic and haemorrhagic events), and all-cause mortality (for alirocumab).

While most of the evidence focused on placebo-controlled trials, there were some trials (six for alirocumab and three for evolocumab) that made direct comparisons against active lipidlowering treatment such as statins or ezetimibe. Due to a relatively low number of accrued events, most comparisons did not favour a protective or harmful effect. Results were of lower certainty (low to very low) due to the low number of events, or due to design choices such as open-label treatment allocation. As such we are uncertain whether PCSK9 mAb would elicit a similar decrease in risk as statins or ezetimibe. In general, there was no convincing evidence for between-study heterogeneity, which provides a crude indicator of the degree of between patient treatment response variation. Likely this lack of observed heterogeneity is closely related to the often modest number of studies available (typically fewer than 10). Trials published to date did not show any potential safety signal on influenza, hypertension, cancer diagnosis, or T2DM. Importantly, the results also do not exclude a potential harmful effect, for which the number of events and precision are too low.

Estimation of the same associations on an RD scale (Table 1; Table 2; Table 3; Table 4) indicates that PCSK9 inhibitors only modestly changed the outcome risk, with an absolute risk (reduction) often less than $1 \%$ over the follow-up period considered.

\section{Overall completeness and applicability of evidence}

Most of the evidence was obtained from people with established atherosclerotic CVD or at high risk of cardiovascular events; therefore, evidence regarding the use of PCSK9 inhibitors for treatment of people at lower risk remains uncertain. Second, information on clinical endpoints for the placebo comparison was based on the large sample size in the FOURIER and ODYSSEY OUTCOMES trials. Often these trials dominated the meta-analysed results. Although these trials were large, median follow-up was less than three years, hence information on long-term efficacy and safety is absent. 
Further, in this review, we focused on any CVD and all-cause mortality, where possible exploring individual elements of CVD such as MI and stroke. In future, it will be important to explore the possible PCSK9 mAb effect on heart failure, atrial fibrillation and stroke subtypes. In a previous version of this review (Schmidt 2017), we additionally explored the possible association between PCSK9 $\mathrm{mAb}$ and cognitive function. The EBBINGHAUS trial (EBBINGHAUS: nested within the FOURIER), utilising a non-inferiority design, disproved such a relation existed over the short to medium followup currently available, and hence we did not explore this endpoint further.

\section{Quality of the evidence}

Although all available data were derived from industrysponsored RCTs, most trials were at low risk of bias, reflecting observations that industry trials are often robustly designed (Zwierzyna 2018). Exceptions were the open-label OSLER trials, which were at high risk of performance bias. Another important potential source of bias was attrition bias, whereby some RCTs included missing observations for more than $5 \%$ of enrolled participants. Most trials tried to minimise this bias by using advanced analytics that explicitly (multiple imputation) or implicitly (mixed-effects models) imputed these missing observations, thus ensuring that all comparisons were made on an ITT basis. The appropriateness of these models (and their underlying assumptions) was not reported, hence these imputation algorithms may have failed to correct for potential attrition bias.

For intended effect and clinical outcomes (i.e. CVD, and allcause mortality) with PCSK9 inhibitors compared with placebo, we graded the certainty of the evidence as high. In the active treatment comparisons, we graded the certainty of the evidence as low (alirocumab), and very low (evolocumab). In the case of alirocumab, we downgraded the evidence because of a reliance on trials with very few outcome events, resulting in a lack of precision and possible small sample size bias. In the case of evolocumab, this was compounded by reliance on open-label designed trials, the data presented separately for the OSLER-2 on ClinicalTrials.gov.

Finally, we observed a discrepancy between the data presented in the published joint analysis of OSLER-1 and OSLER-2 (OSLER-1; OSLER-2), and the data presented separately for the OSLER-2 on ClinicalTrials.gov. To exclude confounding by centre, we decide to use the ClinicalTrials.gov data and meta-analyse this with other evolocumab trials.

\section{Potential biases in the review process}

The meta-analysis presented may show some weaknesses. First, the meta-analysis explored a large number of endpoints, increasing the probability of a false-positive finding. Second, despite our best efforts, we may have failed to identify certain PCSK9 inhibitor trials.

\section{Agreements and disagreements with other studies or reviews}

We are aware of two previous systematic reviews and metaanalyses on PCSK9 inhibitors (Navarese 2015; Zhang 2015); both included a large number of RCTs with short follow-up of 12 weeks, which we excluded here, as well as several longer-term follow-up studies that we did include.
The meta-analysis of Zhang 2015 revealed a protective effect on mortality of alirocumab versus placebo (OR $0.43,95 \% \mathrm{Cl} 0.19$ to 0.96 ) and of alirocumab versus ezetimibe (OR $0.48,95 \% \mathrm{Cl} 0.16$ to 1.45); these effects are similar to those reported here.

Navarese 2015 reported a similarly protective effect of PCSK9 inhibitors (versus all types of comparators) for all-cause mortality (OR $0.45,95 \% \mathrm{Cl} 0.23$ to 0.86 ), as well as protective effects for cardiovascular mortality (OR $0.50,95 \% \mathrm{Cl} 0.23$ to 1.10 ) and MI (OR $0.49,95 \% \mathrm{Cl} 0.26$ to 0.93$)$.

More recently, three independent meta-analyses found no significant effect of PCSK9 mAb on all-cause mortality (contrary to the alirocumab versus placebo effect reported here) (AlTurki 2019; Casula 2019; Torgeon 2018). However, all three meta-analyses not only combined placebo and active therapy arms, they also pooled alirocumab and evolocumab, with AlTurki 2019 even including the terminated PCSK9 mAb bococizumab. However, they did report a similar stroke and MI reduction of PCSK9 inhibition. As expected, based on the EBBINGHAUS results, Torgeon 2018 showed a fairly precise neutral effect of PCSK9 mAb on neurocognitive events (OR $1.02,95 \% \mathrm{Cl} 0.89$ to 1.16$)$. There were similar precise estimates for T2DM (OR 0.96, 95\% Cl 0.91 to 1.02); however, this also included "worsening T2DM" as an endpoint.

The ODYSSEY OUTCOMES trial showed a very similar OR $(0.88$, $95 \% \mathrm{Cl} 0.74$ to 1.05 ) for fatal-CVD (comparing alirocumab versus placebo) as to the all-cause mortality effect presented here.

\section{AUTHORS' CONCLUSIONS}

\section{Implications for practice}

Taken together, there is a strong evidence base for PCSK9 monoclonal antibodies in people who might not be eligible for other lipid-lowering drugs, or to people who cannot meet lipid goals on more traditional therapies.

The evidence base of PCSK9 inhibitors compared with active treatment is much weaker (low- to very low-certainty evidence) and it is unclear whether evolocumab or alirocumab might be effectively used as replacement therapies. Related, most of the available studies preferentially enrolled patients with either established CVD or at a high risk already, and evidence in mediumto low-risk settings is minimal.

Finally, there is very limited evidence on any potential safety issues of both evolocumab and alirocumab. While the current evidence synthesis does not reveal any signals, neither does it provide evidence against such signals. This suggests careful considerations of alternative lipid-lowering treatment before prescribing PCSK9 inhibitors.

\section{Implications for research}

Give the high certainty of evidence for alirocumab and evolocumab (versus placebo) and the similar effects profile on clinical endpoints of both drugs (again versus placebo), it seems highly likely that PCSK9 monoclonal antibodies prevent cardiovascular disease. While evolocumab did not show a significant effect on all-cause mortality, considering the overall agreement with alirocumab, which did show an all-cause mortality effect, this is likely an issue of sample size. 
The most pressing need for longer-term follow-up studies is to elucidate the possible adverse effect profile of both alirocumab and evolocumab, which the current evidence base is not able to address (favouring a protective, harmful, or neutral effect). Depending on the medical need, further studies might consider the effects of alirocumab and evolocumab versus active treatment, for example in primary prevention settings. Despite the similarities of both compounds, this is only based on indirect comparisons and direct comparisons might provide further insights.

\section{ACKNOWLEDGEMENTS}

We are grateful to Carlo Piccini for his constructive peer-review comments. 
R E F E R E N C E S

\section{References to studies included in this review}

Descartes \{published data only\}

Blom DJ, Hala T, Bolognese M, Lillestol MJ, Toth PD, Burgess L, et al. A 52-week placebo-controlled trial of evolocumab in hyperlipidemia. New England Journal of Medicine 2014;370:1809-19.

\section{FOURIER \{published data only\}}

Sabatine MS, Giugliano RP, Keech AC, Honarpour N, Wiviott SD, Murphy SA, et al. Evolocumab and clinical outcomes in patients with cardiovascular disease. New England Journal of Medicine 2017;376(18):1713-22.

\section{GAUSS-3 \{published data only\}}

Nissen SE, Stroes E, Dent-Acosta RE, Rosenson RS, Lehman SJ, Sattar N, et al. Efficacy and tolerability of evolocumab vs ezetimibein patients with muscle-related statin intolerance: the GAUSS-3 randomized clinical trial. JAMA 2016;315(15):1580-90.

GLAGOV \{published data only (unpublished sought but not used)\}

* Nicholls SJ, Puri R, Anderson T, Ballantyne CM, Cho L, Kastelein JJ, et al. Effect of evolocumab on progression of coronary disease in statin-treated patients: the GLAGOV randomized clinical trial. JAMA 2016;316(22):2373-84.

Nicholls SJ, Puri R, Anderson T, Ballantyne CM, Cho L, Katelein JJ, et al. Effect of evolocumab on coronary plaque composition. Journal of the American College of Cardiology 2018;72(17):2012-22.

\section{ODYSSEY ALTERNATIVE \{published data only\}}

Moriarty PM, Thompson PD, Cannon CP, Guyton JR, Bergeron J, Zieve FJ, et al. Efficacy and safety of alirocumab vs ezetimibe in statin-intolerant patients, with a statin rechallenge arm: the ODYSSEY ALTERNATIVE randomized trial. Journal of Clinical Lipidology 2015;9(6):758-69.

\section{ODYSSEY CHOICE I \{published data only\}}

* Roth EM, Moriarty PM, Bergeron J, Langslet G, Manvelian G, Zhao J, et al. A phase III randomized trial evaluating alirocumab $300 \mathrm{mg}$ every 4 weeks as monotherapy or add-on to statin: ODYSSEY CHOICE I. Atherosclerosis 2016;1:254-62.

Stroes E, Guyton JR, Farnier M, Rader D, Moriarty PM, Bergeron J, et al. Efficacy and safety of $150 \mathrm{mg}$ and 300 mg every 3 weeks in patients with poorly controlled hypercholesterolemia: the ODYSSEY CHOICE I and CHOICE II studies. Journal of the American College of Cardiology 2015;5:99.1.

\section{ODYSSEY CHOICE II \{published data only\}}

* Stroes E, Guyton JH, Lepor N, Civeira F, Gaudet D, Watts GF, et al. Efficacy and safety of alirocumab $150 \mathrm{mg}$ every 4 weeks in patients with hypercholesterolemia not on statin therapy: the ODYSSEY CHOICE II Study. Journal of the American Heart Association 2016;1:1-36.

Stroes E, Guyton JR, Farnier M, Rader D, Moriarty PM, Bergeron J, et al. Efficacy and safety of $150 \mathrm{mg}$ and 300 mg every 3 weeks in patients with poorly controlled hypercholesterolemia: the ODYSSEY CHOICE I and CHOICE II studies. Journal of the American College of Cardiology 2015;5:99.1

\section{ODYSSEY COMBO I \{published data only\}}

Kereiakes DJ, Robinson JG, Cannon CP, Lorenzato C, Pordy R, Chaudhari $U$, et al. Efficacy and safety of the proprotein convertase subtilisin/kexin type 9 inhibitor alirocumab among high cardiovascular risk patients on maximally tolerated statin therapy: the ODYSSEY COMBO I study. American Heart Journal 2015;169(6):906.

\section{ODYSSEY COMBO II \{published data only\}}

Cannon CP, Cariou B, Blom D, McKenney JM, Lorenzato C, Pordy R, et al. Efficacy and safety of alirocumab in high cardiovascular risk patients with inadequately controlled hypercholesterolaemia on maximally tolerated doses of statins: the ODYSSEY COMBO II randomized controlled trial. European Heart Journal 2015;36(19):1186-94.

* Shahawy ME, Cannon CP, Blim DJ, McKenney JM, Cariou B, Lecorps $\mathrm{G}$, et al. Efficacy and safety of alirocumab versus ezetimibe over 2 years (from ODYSSEY COMBO II). American Journal of Cardiology 2017;120:931-9.

Shaway ME, Cannon C, Blom D, McKenney J, Cariou B, Lecorps $\mathrm{G}$, et al. Alirocumab versus ezetimibe over 104 weeks in individuals with hypercholesterolemia and high cardiovascular risk: final results from ODYSSEY COMBO II. Journal of Clinical Lipidology 2016;10:717-8.

ODYSSEY DM-DYSLIPIDEMIA \{published data only (unpublished sought but not used)\}

Ray KK, Leiter LA, Muller-Wieland D, Cariou B, Colhoun HM, Henry RR, et al. Alirocumab vs usual lipid-lowering care as add-on to statin therapy in individuals with type 2 diabetes and mixed dyslipidaemia: the ODYSSEY DM-DYSLIPIDEMIA randomized trial. Diabetes, Obesity and Metabolism 2018;20:1479-89.

ODYSSEY DM-INSULIN \{published data only (unpublished sought but not used)\}

Leiter LA, Cariou B, Muller-Wieland D, Colhoun HM, Prato SD, Tinahones FJ, et al. Efficacy and safety of alirocumab in insulintreated individuals with type 1 or type 2 diabetes and high cardiovascular risk: the ODYSSEY DM-INSULIN randomized trial. Diabetes, Obesity and Metabolism 2017;19:1781-92.

\section{ODYSSEY FH I \{published data only\}}

Kastelein JJ, Ginsberg HN, Langslet G, Hovingh GK, Ceska R, Dufour R, et al. ODYSSEY FH I and FH II: 78 week results with alirocumab treatment in 735 patients with heterozygous familial hypercholesterolaemia. European Heart Journal 2015;36(43):2996-3003.

* Kastelein JJ, Hovingh GK, Langslet G, Baccara-Dinet MT, Gipe DA, Chaudhari U, et al. Efficacy and safety of the proprotein convertasesubtilisin/kexin type 9 monoclonal antibody alirocumab vs placebo in patients with heterozygous 
familial hypercholesterolemia. Journal of Clinical Lipidology 2017;11:195-203.

\section{ODYSSEY FH II \{published data only\}}

Kastelein JJ, Ginsberg HN, Langslet G, Hovingh GK, Ceska R, Dufour R, et al. ODYSSEY FH I and FH II: 78 week results with alirocumab treatment in 735 patients with heterozygous familial hypercholesterolaemia. European Heart Journal 2015;36(43):2996-3003.

* Kastelein JJ, Hovingh GK, Langslet G, Baccara-Dinet MT, Gipe DA, Chaudhari U, et al. Efficacy and safety of the proprotein convertasesubtilisin/kexin type 9 monoclonal antibody alirocumab vs placebo in patients with heterozygous familial hypercholesterolemia. Journal of Clinical Lipidology 2017;11:195-203.

\section{ODYSSEY HIGH FH \{published data only\}}

Ginsberg HN, Rader DJ, Raal F, Guyton JR, Lorenzato C, Pordy R, et al. ODYSSEY HIGH FH: efficacy and safety of alirocumab in patients with severe heterozygous familial hypercholesterolemia. www.resource.heartonline.cn/20150520/2_NaN0BW2.pdf (accessed online 2014).

* Ginsberg HN, Rader DJ, Raal FJ, Guyton JH, Baccara-Dinet MT, Lorenzato $\mathrm{C}$, et al. Efficacy and safety of alirocumab in patients with heterozygous familial hypercholesterolemia and LDLC of $160 \mathrm{mg} / \mathrm{dl}$ or higher. Cardiovascular Drugs Therapy 2016;30:473-83.

ODYSSEY JAPAN \{published data only (unpublished sought but not used)\}

Teramoto T, Kobayashi M, Tasaki H, Yagyu H, Higashikata T, Takagi Y, et al. Efficacy and safety of alirocumab in Japanese patients with heterozygous familial hypercholesterolemia or at high cardiovascular risk with hypercholesterolemia not adequately controlled with statins - ODYSSEY JAPAN randomized controlled trial. Circulation Journal 2016;80:1980-7.

ODYSSEY KT \{published data only (unpublished sought but not used)\}

* Koh KK, Nam CW, Chao TH, Liu ME, Wu CJ, Kim DS, et al. A randomized trial evaluating the efficacy and safety of alirocumab in South Korea and Taiwan (ODYSSEY KT). Journal of Clinical Lipidology 2018;12(1):162-72.

Koh KK, Nam CW, Chao TH, Liu ME, Wu CJ, Kim DS, et al. A randomized, double-blind, placebo-controlled, parallel group study to evaluate the efficacy and safety of alirocumab in high cardiovascular risk patients with hypercholesterolemia not adequately controlled with their lipid modifying therapy in South Korea and Taiwan. Journal of the American College of Cardiology 2017;69(11):1664.

\section{ODYSSEY Long Term \{published data only\}}

Robinson JG, Farnier M, Krempf M, Bergeron J, Luc G, Averna M, et al. Efficacy and safety of alirocumab in reducing lipids and cardiovascular events. New England Journal of Medicine 2015;372(16):1489-99.

\section{ODYSSEY MONO \{published data only\}}

Roth EM, Taskinen MR, Ginsberg HN, Kastelein JJ, Colhoun HM, Robinson JG, et al. Monotherapy with the PCSK9 inhibitor alirocumab versus ezetimibe in patients with hypercholesterolemia: results of a 24 week, double-blind, randomized phase 3 trial. International Journal of Cardiology 2014;176:55-61.

\section{ODYSSEY OPTIONS I \{published data only\}}

Bays H, Gaudet D, Weiss R, Ruiz JL, Watts GF, Gouni-Berthold I, et al. Alirocumab as add-on to atorvastatin versus other lipid treatment strategies: ODYSSEY OPTIONS I randomized trial. Journal of Clinical Endocrinology and Metabolism 2015;100(8):3140-8.

\section{ODYSSEY OPTIONS II \{published data only\}}

Farnier M, Jones P, Severance R, Averna M, SteinhagenThiessen E, Colhoun HM, et al. Efficacy and safety of adding alirocumab to rosuvastatin versus adding ezetimibe or doubling the rosuvastatin dose in high cardiovascular-risk patients: the ODYSSEY OPTIONS II randomized trial. Atherosclerosis 2016;244:138-46.

\section{ODYSSEY OUTCOMES \{published data only (unpublished sought} but not used)\}

Schwartz GG, Steg PG, Szarek M, Bhatt DL, Bittner RD, Edelberg JM, et al. Alirocumab and cardiovascular outcomes after acute coronary syndrome. New England Journal of Medicine 2018;379(22):2097-107.

\section{OSLER-1 \{published data only\}}

Koren M, Sabatine M, Giugliano R, Langslet G, Wiviott S, Ruzza A, et al. Final report of the OSLER-1 study: long-term evolocumab for the treatment of hypercholesterolemia. Journal of Clinical Lipidology 2019;13:e53-e54.

Koren MJ, Giugliano RP, Raal FJ, Sullivan D, Bolognese M, Langslet $\mathrm{G}$, et al. Efficacy and safety of longer-term administration of evolocumab (AMG 145) in patients with hypercholesterolemia: 52-week results from the openlabel study of long-term evaluation against LDL-C (OSLER) randomized trial. Circulation 2014;129:234-43.

\section{OSLER-2 \{published and unpublished data\}}

NCT01854918. Open-label extension study of evolocumab (AMG 145 ) in adults with hyperlipidemia and mixed dyslipidemia. clinicaltrials.gov/ct2/show/results/NCT01854918 (first received 16 May 2013). [CLINICALTRIALS.GOV: clinicaltrials.gov/ct2/show/ results/NCT01854918]

\section{Sugizaki 2019 \{published data only\}}

Sugizaki Y, Otake H, Kawamori H, Toba T, Nagasawa A, Onishi H, et al. Alirocumab improve coronary plaque vulnerability: first randomized control trial to assess the effect of alirocumab for plaque vulnerability using optical coherence tomography. Journal of the American College of Cardiology 2019;74:B13. 


\section{References to studies excluded from this review}

\section{ANITSCHKOW \{published data only\}}

NCT02729025. Effects of proprotein convertase subtilisin/kexin type 9 (PCSK9) inhibition on arterial wall inflammation study in patients with elevated lipoprotein(a) (LP(a)). (ANITSCHKOW). clinicaltrials.gov/ct2/show/NCT02729025 (first received 8 March 2016).

Stiekema LC, Stroes ES, Verweije SL, Kassahun LC, Chen L, Wasserman SM, et al. Persistent arterial wall inflammation in patients with elevated lipoprotein(a) despite strong low-density lipoprotein cholesterol reduction by proprotein convertase subtilisin/kexin type 9 antibody treatment. European Heart Journal 2018;0:1-8.

Ballantyne 2015 \{published data only (unpublished sought but not used)\}

Ballantyne CM, Neutel J, Cropp A, Duggan W, Wang EQ, Plowchalk D, et al. Results of bococizumab, a monoclonal antibody against proprotein convertase subtilisin/kexin type9, from a randomized, placebo-controlled, dose-ranging study in statin-treated subjects with hypercholesterolemia. American Journal of Cardiology 2015;115(9):1212-21.

Baruch 2013 \{published data only\}

Baruch A, Peng K, Leabman M, Budha N, Luca D, Cowan KJ, et al. Effect of RG7652, a mAb against PCSK9, on apolipoprotein $B$, oxidized LDL, lipoprotein $(A)$ and lipoprotein-associated phospholipase a2 in healthy individuals with elevated LDL-C. Circulation 2013;128:A12009.

Cho 2014 \{published data only\}

Cho L, Rocco M, Colquhoun D, Sullivan D, Rosenson RS, Dent $\mathrm{R}$, et al. Clinical profile of statin intolerance in the phase 3 GAUSS-2 study. Canadian Journal of Cardiology 2014;30(10, Supplement):S79.

\section{Desai 2014 \{published data only\}}

Desai NR, Giugliano RP, Zhou J, Kohli P, Somaratne R, Hoffman E, et al. AMG 145, a monoclonal antibody against PCSK9, facilitates achievement of National Cholesterol Education Program-Adult Treatment Panel III low-density lipoprotein cholesterol goals among high-risk patients: an analysis from the LAPLACE-TIMI 57 trial (LDL-C assessment with PCSK9 monoclonal antibody inhibition combined with statin therapy-thrombolysis in myocardial infarction 57). Journal of the American College of Cardiology 2014;63:430-3.

\section{Dias 2012 \{published data only\}}

Dias CS, Shaywitz AJ, Wasserman SM, Smith BP, Gao B, Stolman DS, et al. Effects of AMG 145 on low-density lipoprotein cholesterol levels: results from 2 randomized, double-blind, placebo-controlled, ascending-dose phase 1 studies in healthy volunteers and hypercholesterolemic subjects on statins. Journal of the American College of Cardiology 2012;60:1888-98.

Dufour 2012 \{published data only\}

Dufour R, Moriarty PM, Genestin E, Sasiela WJ, Du Y, Ferrand AC, et al. Effect of REGN727/SAR236553 anti-proprotein convertase subtilisin/kexin type 9 fully human monoclonal antibody in patients with elevated triglycerides/low high- density lipoprotein cholesterol: data from three phase 2 studies (NCT:01266876; 01288469; 01288443). Circulation 2012;126:A16127.

\section{EBBINGHAUS \{published data only\}}

NCT02207634. Evaluating PCSK9 Binding antiBody Influence oN coGnitive HeAlth in High cardiovascUlar Risk Subjects (EBBINGHAUS). clinicaltrials.gov/ct2/show/NCT02207634 (first received 31 July 2014).

EQUATOR \{published data only (unpublished sought but not used)\}

Tingley W, Mosesova S, Baruch A, Davis JD, Budha N, Vilimovskij A, et al. Effects of RG7652, a monoclonal antibody against proprotein convertase subtilisin/kexintype 9, on LDL cholesterol in patients with coronary heart disease or high risk: results from the EQUATOR study. European Heart Journal 2014;35:371.

\section{Gaudet 2012 \{published data only\}}

Gaudet D, Kereiakes D, McKenney J, Roth E, Hanotin C, Gipe D, et al. Effect of SAR236553/REGN727 fully human monoclonal anti-proprotein convertase subtilisin/kexin type 9 antibody on plasma lipoprotein(a) concentrations: pooled analysis from three phase 2 studies (NCT:01266876; 01288469; 01288443). Circulation 2012;126:A14725.

Gaudet 2013 \{published data only\}

Gaudet D, Kereiakes D, McKenney J, Roth E, Hanotin C, Gipe D, et al. Alirocumab, a fully human monoclonal antibody to PCSK9, reduces high plasma Ip(a) concentration: pooled analysis of 352 patients from phase 2. Journal of Clinical Lipidology 2013;7(3):283-4.

\section{Gumbiner 2012 \{published data only\}}

Gumbiner B, Udata C, Joh T, Liang H, Wan H, Shelton D, et al. The effects of multiple dose administration of RN316 (PF-04950619), a humanized IgG2a monoclonal antibody binding proprotein convertase snbtilisin kexin type 9 , in hypercholesterolemic subjects. Circulation 2012;126:21.

\section{Habibinejad 2016 \{published data only\}}

Habibinejad $\mathrm{H}$, Khosrokhavar $\mathrm{F}$. The effects of alirocumab on LDL cholesterol in patients receiving statins. Canadian Journal of Cardiology 2016;32(10 Suppl 1):S122.

\section{HAUSER-RCT \{published data only\}}

NCT02392559. Trial assessing efficacy, safety and tolerability of PCSK9 inhibition in paediatric subjects with genetic LDL disorders (HAUSER-RCT). clinicaltrials.gov/ct2/show/ NCT02392559 (first received 25 February 2015).

\section{Hopkins 2013 \{published data only\}}

Hopkins PN, Swergold GD, Mellis S, Bruckert E, Luc G, Mendoza J, et al. A randomized placebo-phase clinical trial with the monoclonal antibody alirocumab demonstrates reductions in low-density lipoprotein cholesterol in patients with proprotein convertase subtilisin/kexin type 9 gain-offunction mutations. Circulation 2013;128(22):A17156. 
Jones 2015 \{published data only\}

Jones PH, Bays H, Chaudhari U, Pordy R, Lorenzato C, Miller K, et al. Pooled safety and adverse events in nine randomized, placebo-controlled, phase 2 and 3 clinical trials of alirocumab. Journal of the American College of Cardiology 2015;65(10 Supplement):A1363.

\section{Kastelein 2015 \{published data only\}}

Kastelein J, Nissen S, Rader D, Krueger K, Wang MD. Safety and efficacy of LY 3015014, a new monoclonal antibody to proprotein convertase subtilisin/kexin type 9 (PCSK 9) with an inherently longer duration of action, in patients with primary hypercholesterolemia: a randomized, placebo-controlled, dose-ranging, phase 2 study. Journal of the American College of Cardiology 2015;65:A1591.

\section{Kawashiri 2012 \{published data only\}}

Kawashiri MA, Nohara A, Noguchi T, Tada H, Nakanishi C, Mori M, et al. Efficacy and safety of coadministration of rosuvastatin, ezetimibe, and colestimide in heterozygous familial hypercholesterolemia. American Journal of Cardiology 2012;109:364-9.

\section{Mabuchi 2015 \{published data only\}}

Mabuchi H, Nohara A. Therapy: PCSK9 inhibitors for treating familial hypercholesterolaemia. Nature Reviews Endocrinology 2015;11(1):8-9.

\section{Maxwell 2012 \{published data only\}}

Maxwell KN, Breslow JL. Antibodies to PCSK9: a superior way to lower LDL cholesterol? Circulation Research 2012;111:274-7.

\section{Mearns 2014 \{published data only\}}

Mearns BM. Dyslipidaemia: 1-year results from OSLER trial of anti-PCSK9 monoclonal antibody evolocumab. Nature Reviews Cardiology 2014;11:63.

\section{Pordy 2013 \{published data only\}}

Pordy R, Lecorps G, Bessac L, Sasiela WJ, Ginsberg H. Alirocumab, a fully human monoclonal antibody to proprotein convertase subtilisin/kexin type 9: therapeutic dosing in phase 3 studies. Journal of Clinical Lipidology 2013;7(3):279.

\section{Raal 2014a \{published data only\}}

Raal F, Giugliano RP, Sabatine MS, Koren MJ, Blom D, Honarpour N, et al. Long-term reduction in lipoprotein(A) with the PCSK9 monoclonal antibody evolocumab (AMG 145): a pooled analysis of 3278 patients in phase 2,3 , and open label extension studies. Circulation 2014;130:A15743.

Raal 2014b \{published data only\}

Raal F, Nelson P, Langslet G, Basart DC, Civeira F, LopezMiranda J, et al. Safety, tolerability, and efficacy of longterm administration of monthly AMG 145 in subjects with heterozygous familial hypercholesterolemia. Global Heart 2014;1:e139.

\section{Shaywitz 2012 \{published data only\}}

Shaywitz AJ, Dias C, Smith B, Gao B, Gibbs J, Emery M, et al. AMG 145, a fully human monoclonal antibody against PCSK9, reduces $L D L-C$ in healthy volunteers and patients on stable doses of statins. Journal of Clinical Lipidology 2012;6(3):286-7.

SPIRE 1/2 \{published data only\}

Ridker PM, Revking J, Amarenco P, Brunell R, Curto M, Civeria F, et al. Cardiovascular efficacy and safety of bococizumab in high-risk patients. New England Journal of Medicine 2017;376:1527-39.

SPIRE biomarker trials \{published data only\}

Ridker PM, Tardif JC, Amarenco P, Duggan W, Glyn RJ, Jukema WJ, et al. Lipid-reduction variability and antidrugantibody formation with bococizumab. New England Journal of Medicine 2017; online first:1-10.

Stawowy 2014 \{published data only\}

Stawowy P, Just IA, Kaschina E. Inhibition of PCSK9: a novel approach for the treatment of dyslipidemia. Coronary Artery Disease 2014;25:353-9.

Stein 2012 \{published data only\}

Stein EA, Mellis S, Yancopoulos GD, Stahl N, Logan D, Smith WB, et al. Effect of a monoclonal antibody to PCSK9 on LDL cholesterol. New England Journal of Medicine 2012;366:1108-18.

Stein 2013 \{published data only\}

Stein EA, Somaratne R, Schou MB, Civeira F, Sullivan D, Watts GF, et al. Efficacy and tolerability of long-term treatment with AMG 145 in patients with statin intolerance. Circulation 2013;128:A12621.

\section{Swergold 2010 \{published data only\}}

Swergold G, Biedermann S, Renard R, Nadler D, Wu R, Mellis S. Safety, lipid, and lipoprotein effects of REGN727/SAR236553, a fully-human proprotein convertase subtilisin kexin 9 (PCSK9) monoclonal antibody administered intravenously to healthy volunteers. Circulation 2010;122:2.

\section{Swergold 2011 \{published data only\}}

Swergold G, Smith W, Mellis S, Logan D, Webb C, Wu R, et al. Inhibition of proprotein convertase subtilisin/kexin type 9 with a monoclonal antibody REGN727/SAR236553, effectively reduces low-density-lipoprotein cholesterol, as mono or add-on therapy in heterozygous familial and non familial hypercholesterolemia. Circulation 2011;124:2.

\section{TAUSSIG \{published data only\}}

NCT01624142. Trial assessing long term use of PCSK9 inhibition in subjects with genetic LDL disorders (TAUSSIG). clinicaltrials.gov/ct2/show/NCT01624142 (first received 5 June 2012).

Raal FJ, Hoving GK, Blom D, Santos RD, Harada-Shiba M, Bruckert E. Long-term treatment with evolocumab added to conventional drug therapy, with or without apheresis, in patients with homozygous familial hypercholesterolaemia: an interim subset analysis of the open-label TAUSSIG study. Lancet Diabetes \& Endocrinology 2017;5:280-90. 
Wan 2013 \{published data only\}

Wan H, Gumbiner B, Joh T, Udata C, Forgues P, Garzone PD. Effects of RN316 (pf-04950615), a humanized IgG2a monoclonal antibody binding proprotein convertase subtilisin kexin type 9, on lipoprotein particles in hypercholesterolemic subjects. Journal of the American College of Cardiology 2013;31:E1387.

\section{References to ongoing studies}

ALTAIR \{published data only\}

Otak H, Sugizaki Y, Toba T, Nagano Y, Tsukiyama Y, Yanaka KI, et al. Efficacy of alirocumab for reducing plaque vulnerability: study protocol for ALTAIR, a randomized controlled trial in Japanese patients with coronary artery disease receiving rosuvastatin. Journal of Cardiology 2019;73:228-32.

\section{EVOLVD \{published data only\}}

Broch K, Gustafsson F, Radegran G, Karl LB, Eiskjnr H, Gjesdal G, et al. EVOLVD: cholesterol lowering with EVOLocumab to prevent cardiac allograft vasculopathy in de-novo heart transplant recipients: rationale and design of a randomized, controlled trial. Journal of Heart and Lung Transplantation 2019;38:S279.

\section{NCT02833844 \{published data only\}}

NCT02833844. Safety, tolerability \& efficacy on LDL-C of evolocumab in subjects with HIV \& hyperlipidemia/mixed dyslipidemia. clinicaltrials.gov/ct2/show/NCT02833844 (first received 13 June 2016).

\section{UMIN000034592 \{unpublished data only\}}

NA. Ongoing study. 26 October 2018. Contact author for more information.

\section{Additional references}

\section{Abifadel 2003}

Abifadel M, Varret M, Rabès JP, Allard D, Ouguerram K, Devillers $\mathrm{M}$, et al. Mutations in PCSK9 cause autosomal dominant hypercholesterolemia. Nature Genetics 2013;34(2):154-6.

\section{AlTurki 2019}

AlTurki A, Marafi M, Dawas A, Dube MP, Vieira L, Sherman MH, et al. Meta-analysis of randomized controlled trials assessing the impact of proprotein convertase subtilisin/kexin type 9 antibodies on mortality and cardiovascular outcomes. American Journal of Cardiology 2019;124:1869-75.

\section{Benn 2010}

Benn M, Nordestgaard BG, Grande P, Schnohr P, TybjaergHansen A. PCSK9 R46L, low-density lipoprotein cholesterol levels, and risk of ischemic heart disease: 3 independent studies and meta-analyses. Journal of the American College of Cardiology 2010;55(22):2833-42.

\section{Benn 2012}

Benn M, Watts GF, Tybjaerg-Hansen A, Nordestgaard BG. Familial hypercholesterolemia in the Danish general population: prevalence, coronary artery disease, and cholesterol-lowering medication. Journal of Clinical Endocrinology and Metabolism 2012;97(11):3956-64.

\section{Bradburn 2007}

Bradburn MJ, Deeks JJ, Berlin JA, Localio AR. Much ado about nothing: a comparison of the performance of metaanalytical methods with rare events. Statistics in Medicine 2007;26(1):53-77.

\section{Cannon 2015}

Cannon CP, Blazing MA, Giugliano RP, McCagg A, White JA, Theroux $P$, et al. Ezetimibe added to statin therapy after acute coronary syndromes. New England Journal of Medicine 2015;372(25):2387-97.

\section{Casula 2019}

Casula M, Olmastroni E, Taddeo MB, Tragni E, Pirillo A, Catapano AL. Safety and cardiovascular efficacy of antiPCSK9 monoclonal antibodies: a meta-analysis of randomised controlled trials. Atherosclerosis 2019;287:e39.

\section{Catapano 2013}

Catapano AL, Papadopoulos N. The safety of therapeutic monoclonal antibodies: implications for cardiovascular disease and targeting the PCSK9 pathway. Atherosclerosis 2013;228(1):18-28.

\section{Catapano 2016}

Catapano AL, Graham I, De Backer G, Wiklund O, Chapman MJ, Drexel $\mathrm{H}$, et al. $2016 \mathrm{ESC} / \mathrm{EAS}$ guidelines for the management of dyslipidaemias. European Heart Journal 2016;37(39):2999-3058.

\section{Chasman 2012}

Chasman DI, Giulianini F, MacFadyen J, Barratt BJ, Nyberg F, Ridker PM. Genetic determinants of statin-induced low-density lipoprotein cholesterol reduction: the Justification for the Use of Statins in Prevention: an Intervention Trial Evaluating Rosuvastatin (JUPITER) trial. Circulation. Cardiovascular Genetics 2012;5(2):257-64.

\section{Cohen 2005}

Cohen J, Pertsemlidis A, Kotowski IK, Graham R, Garcia CK, Hobbs HH. Low LDL cholesterol in individuals of African descent resulting from frequent nonsense mutations in PCSK9. Nature Genetics 2005;37(2):161-5.

\section{Cohen 2006}

Cohen JC, Boerwinkle E, Mosley TH Jr, Hobbs HH. Sequence variations in PCSK9, low LDL, and protection against coronary heart disease. New England Journal of Medicine 2006;354(12):1264-72.

\section{Collins 2016}

Collins R, Reith C, Emberson J, Armitage J, Baigent C, Blackwell L, et al. Interpretation of the evidence for the efficacy and safety of statin therapy. Lancet 2016;388(10059):2532-61.

\section{CTT 2005a}

Cholesterol Treatment Trialists' (CTT) Collaborators. Efficacy and safety of cholesterol-lowering treatment: prospective meta- 
analysis of data from 90,056 participants in 14 randomised trials of statins. Lancet 2005;366(9493):1267-78.

\section{CTT 2005b}

Cholesterol Treatment Trialists' (CTT) Collaboration, Fulcher J, O'Connell R, Voysey M, Emberson J, Blackwell L, Mihaylova B, et al. Efficacy and safety of LDL-lowering therapy among men and women: meta-analysis of individual data from 174000 participants in 27 randomised trials. Lancet 2005;385(9976):1397-405.

\section{CTT 2012}

Cholesterol Treatment Trialists' (CTT) Collaborators, Mihaylova B, Emberson J, Blackwell L, Keech A, Simes J, Barnes EH, et al. The effects of lowering LDL cholesterol with statin therapy in people at low risk of vascular disease: metaanalysis of individual data from 27 randomised trials. Lancet 2012;380(9841):581-90.

\section{Farnier 2014}

Farnier M. PCSK9: from discovery to therapeutic applications. Archives of Cardiovascular Disease 2014;107(1):58-66.

\section{FDA 2015}

Food and Drug Administration Center for Drug Evaluation and Research. Briefing document Praluent (alirocumab) injection. The Endocrinologic and Metabolic Drugs Advisory Committee Meeting 2015;BLA 125559.

\section{Garcia 2001}

Garcia CK, Wilund K, Arca M, Zuliani G, Fellin R, Maioli M, et al. Autosomal recessive hypercholesterolemia caused by mutations in a putative LDL receptor adaptor protein. Science 2001;292(5520):1934-8.

\section{Grade Working Group 2004}

GRADE Working Group. Grading quality of evidence and strength of recommendations. BMJ 2004;328(1):1490-4.

\section{Grundy 2004}

Grundy SM, Cleeman JI, Merz CN, Brewer HB Jr, Clark LT, Hunninghake DB, et al. Implications of recent clinical trials for the National Cholesterol Education Program Adult Treatment Panel III Guidelines. Journal of the American College of Cardiology 2004;44(3):720-32.

\section{Higgins 2011}

Higgins JP, Altman DG, Sterne JA. Chapter 8: Assessing risk of bias in included studies. In: Higgins JP, Green S, editor(s). Cochrane Handbook for Systematic Reviews of Interventions. Version 5.1.0 (updated March 2011). The Cochrane Collaboration, 2011. Available from handbook.cochrane.org.

\section{Innerarity 1987}

Innerarity TL, Weisgraber KH, Arnold KS, Mahley RW, Krauss RM, Vega GL, et al. Familial defective apolipoprotein B-100: low density lipoproteins with abnormal receptor binding. Proceedings of the National Academy of Sciences of the United States of America 1987;84:6919-23.

\section{Knowles 2014}

Knowles JW, O'Brein EC, Greendale K, Wilemon K, Genest J, Sperling LS, et al. Reducing the burden of disease and death from familial hypercholesterolemia: a call to action. American Heart Journal 2014;168(6):807-11.

\section{Lefebvre 2011}

Lefebvre C, Manheimer E, Glanville J. Chapter 6: Searching for studies. In: Higgins JP, Green S, editor(s). Cochrane Handbook for Systematic Reviews of Interventions Version 5.1.0 (updated March 2011). The Cochrane Collaboration, 2011. Available from handbook.cochrane.org.

\section{Mancini 2011}

Mancini GB, Baker S, Bergeron J, Fitchett D, Frohlich J, Genest J, et al. Diagnosis, prevention, and management of statin adverse effects and intolerance: proceedings of a Canadian Working Group Consensus Conference. Canadian Journal of Cardiology 2011;27(5):635-62.

\section{Marks 2003}

Marks D, Thorogood M, Neil HA, Humpries SE. A review on the diagnosis, natural history, and treatment of familial hypercholesterolaemia. Atherosclerosis 2003;168(1):1-14.

\section{Navarese 2015}

Navarese EP, Kołodziejczak M, Schulze V, Gurbel PA, Tantry U, et al. Effects of proprotein convertase subtilisin/kexin type 9 antibodies in adults with hypercholesterolemia: a systematic review and meta-analysis. Annals of Internal Medicine 2015;163(1):40-51. [DOI: 10.7326/M14-2957]

\section{Newcombe 2014}

Newcombe RG, Bender R. Implementing GRADE: calculating the risk difference from the baseline risk and the relative risk. Evidence-Based Medicine 2014;19(1):6-8.

\section{Nissen 2016}

Nissen SE, Stroes E, Dent-Acosta RE, Rosenson RS, Lehman SJ, Sattar N, et al. Efficacy and tolerability of evolocumab vs ezetimibe in patients with muscle-related statin intolerance: the GAUSS-3 randomized clinical trial. JAMA 2016;315(15):1580-90.

\section{Nordestgaard 2013}

Nordestgaard BG, Chapman MJ, Humphries SE, Ginsberg HN, Masana L, Descamps OS, et al. Familial hypercholesterolaemia is underdiagnosed and undertreated in the general population: guidance for clinicians to prevent coronary heart disease. European Heart Journal 2013;34(45):3478-90.

\section{Pfizer 2017}

Pfizer. Pfizer discontinues global development of bococizumab, its investigational PCSK9 inhibitor. www.pfizer.com/news/press-release/press-release-detail/ pfizer_discontinues_global_development_of_bococizumab_its_investigati (accessed 24 April 2017).

\section{Review Manager 2014 [Computer program]}

Nordic Cochrane Centre, The Cochrane Collaboration Review Manager 5 (RevMan 5). Version 5.4. Copenhagen: Nordic Cochrane Centre, The Cochrane Collaboration, 2014. 


\section{Sattar 2010}

Sattar N, Preiss D, Murray HM, Welsh P, Buckley BM, de Craen AJ, et al. Statins and risk of incident diabetes: a collaborative meta-analysis of randomised statin trials. Lancet 2010;375(9716):735-42.

\section{Schmidt 2015}

Schmidt AF, Pearce LS, Wilkins JP, Overington JP, Hingorani A, Casas JP. PCSK9 monoclonal antibodies for the primary and secondary prevention of cardiovascular disease. Cochrane Database of Systematic Reviews 2015, Issue 6. Art. No: CD011748. [DOI: 10.1002/14651858.CD011748]

\section{Seidah 2003}

Seidah NG, Benjannet S, Wickham L, Marcinkiewicz J, Jasmin SB, Stifani S, et al. The secretory proprotein convertase neural apoptosis-regulated convertase 1 (NARC-1): liver regeneration and neuronal differentiation. Proceedings of the National Academy of Sciences of the United States of America 2003;100(3):928-33.

\section{Sudhof 1985}

Sudhof TC, Goldstein JL, Brown MS, Russell DW. The LDL receptor gene: a mosaic of exons shared with different proteins. Science 1985;228(4701):815-22.

\section{Sweeting 2004}

Sweeting MJ, Sutton AJ, Lambert, PC. What to add to nothing? Use and avoidance of continuity corrections in meta-analysis of sparse data. Statistics in Medicine 2004;23(1):1351-75.

\section{Swerdlow 2014}

Swerdlow DI, Preiss D, Kuchenbaecker KB, Holmes MV, Engmann JE, Shah T, et al. HMG-coenzyme A reductase inhibition, type 2 diabetes, and bodyweight: evidence from genetic analysis and randomised trials. Lancet 2014;385(9965):351-61.

\section{Torgeon 2018}

Torgeon RD, Tsuyuki RT, Gyenes GT, Pearson GJ. Cardiovascular efficacy and safety of PCSK9 inhibitors: systematic review and meta-analysis including the ODYSSEY OUTCOMES trial. Canadian Journal of Cardiology 2018;34:1600-5.

\section{Willer 2013}

Global Lipids Genetics Consortium, Willer CJ, Schmidt EM, Sengupta S, Peloso GM, Gustafsson S, Kanoni S, et al. Discovery and refinement of loci associated with lipid levels. Nature Genetics 2013;45(11):1274-83.

\section{Zhang 2015}

Zhang XL, Zhu QQ, Zhu L, Chen JZ, Chen QH, Li QN, et al. Safety and efficacy of anti-PCSK9 antibodies: a meta-analysis of 25 randomized, controlled trials. BMC Medicine 2015;13(123):1-19.

\section{Zwierzyna 2018}

Zwierzyna M, Davies M, Hingorani AD, Hunter J. Clinical trial design and dissemination: comprehensive analysis of clinicaltrials.gov and PubMed data since 2005. BMJ 2018;361:1-11.

\section{References to other published versions of this review}

\section{Schmidt 2017}

Schmidt AF, Pearce LS, Wilkins JT, Overington JP, Hingorani AD, Casas JP. PCSK9 monoclonal antibodies for the primary and secondary prevention of cardiovascular disease. Cochrane Database of Systematic Reviews 2017, Issue 4. Art. No: CD011748. [DOI: 10.1002/14651858.CD011748.pub2]

* Indicates the major publication for the study

\section{CHARACTERISTICS OF STUDIES}

Characteristics of included studies [ordered by study ID]

\section{Descartes}

\section{Study characteristics}

Methods Type of RCT: 2:1 parallel-group, double-blind RCT with stratified randomisation

Settings: outpatient care

Duration: 52 weeks

Start and stop dates: January 2012 and November 2013

Participants Number of participants: 905 (901 with baseline data)

Number lost to follow-up: 134

Women: $471(52 \%)$

Mean age (SD), years: $56(11)$ 
Descartes (Continued)

History of CVD: 136 (15\%)

Participants with FH: NA

Participants with fasting LDL-C $\geq 75 \mathrm{mg} / \mathrm{dL}$ and fasting TG $400 \mathrm{mg} / \mathrm{dL}$

Interventions

Background therapy: SOC, which consisted of diet only, daily atorvastatin $10 \mathrm{mg}, 80 \mathrm{mg}$, or $80 \mathrm{mg}+$ ezetimibe $10 \mathrm{mg}$

Randomised therapy: evolocumab every 4 weeks vs placebo

Evolocumab dose: 48 weeks of $420 \mathrm{mg}$ each 4 weeks. 2-week equivalent dose of $210 \mathrm{mg}$

\begin{tabular}{ll}
\hline Outcomes & CVD, all-cause mortality \\
\hline Notes & All lipid analyses performed by Medpace Reference Laboratories (MRL). Laboratories maintained Part \\
III certification according to the CDC Lipid Standardization Program throughout the study. \\
- LDL-C and very low-density lipoprotein cholesterol measured after preparative ultracentrifugation ( $\beta$ - \\
quantification). Calculated LDL-C using Friedewald formula. \\
- TGs and cholesterol measured with enzymatic colorimetric tests (Olympus AU2700 or AU5400 Analyz- \\
er, Olympus, Center Valley, PA) with calibration directly traceable to CDC reference procedures. \\
- ApoB-containing lipoproteins precipitated with dextran sulphate, and HDL-C was measured in the su- \\
pernatant. ApoA1 and ApoB were measured with rate immunonephelometry (Dade Behring BNII neph- \\
elometer, Siemens Healthcare Diagnostics, Deerfield, IL), and Lp(a) was measured by immuno tur- \\
bidimetry (Denka Seiken Co. Ltd. Lp(a) assay from Polymedco, Cortlandt Manor, NY, on the Olympus \\
Analyzer). \\
- NCT01516879 \\
- Parent trial of OSLER-2 \\
Funded by Amgen
\end{tabular}

\title{
Risk of bias
}

\begin{tabular}{lll}
\hline Bias & Authors' judgement & Support for judgement \\
\hline $\begin{array}{l}\text { Random sequence genera- } \\
\text { tion (selection bias) }\end{array}$ & Low risk & $\begin{array}{l}\text { Randomisation performed centrally using an interactive voice-response sys- } \\
\text { tem. }\end{array}$ \\
\hline $\begin{array}{l}\text { Allocation concealment } \\
\text { (selection bias) }\end{array}$ & Low risk & Randomisation performed centrally using an interactive system. \\
\hline $\begin{array}{l}\text { Blinding of participants } \\
\begin{array}{l}\text { and personnel (perfor- } \\
\text { mance bias) } \\
\text { All outcomes }\end{array}\end{array}$ Unclear risk & $\begin{array}{l}\text { Although paper and appendix described the study as double-blind, it was un- } \\
\text { clear how this was maintained and who was blinded. Lack of blinding will like- } \\
\text { ly cause a change in adherence or participant choices regarding SOC/lifestyle } \\
\text { (or both), which may influence outcomes. }\end{array}$
\end{tabular}

\section{Blinding of outcome as- Low risk} sessment (detection bias)

All outcomes

\begin{abstract}
Although paper and appendix described the study as double-blind, it was unclear how this was maintained and who was blinded. However, any lack of blinding of participants and personnel seems unlikely to bias LDL-C assessment, which was performed in independent laboratories. Outcomes such as adverse events may be biased owing to detection bias.
\end{abstract}

Incomplete outcome data High risk
(attrition bias)
All outcomes

\begin{abstract}
4 participants were randomised but were not included in the ITT (small number, good). However, at 2 weeks of follow-up, the number of available participants had decreased by about 15\% (number of missing measurements 44 $(14.57 \%)$ in comparison arm, and 90 (15.03\%) in intervention arm). In some cases, missing participants were likely due to different enrolment times, limiting follow-up; however, reported numbers of discontinued participants were similarly high: 73 in the evolocumab arm and 28 in the placebo arm. Missing LDL-C data were imputed using linear-mixed models, including baseline mea-
\end{abstract}


Descartes (Continued)

surements. Other missing lipid measurements were imputed using a last observation carried forward approach and were analysed by ANCOVA.

\begin{tabular}{lll}
\hline $\begin{array}{l}\text { Selective reporting (re- } \\
\text { porting bias) }\end{array}$ & Low risk & Reported most endpoints. \\
\hline Other bias & Low risk & No concerns outside the assessed risk of bias domains. \\
\hline
\end{tabular}

\section{FOURIER}

\section{Study characteristics}

\begin{tabular}{|c|c|}
\hline Methods & $\begin{array}{l}\text { Type of RCT: } 1: 1 \text { parallel-group, double-blind RCT } \\
\text { Settings: outpatient care } \\
\text { Duration: } 157 \text { weeks ( } 36 \text { months) } \\
\text { Start and stop dates: February } 2013 \text { and November } 2016\end{array}$ \\
\hline Participants & $\begin{array}{l}\text { Number of participants: } 27,564 \text { ( } 39 \text { did not receive treatment) } \\
\text { Number lost to follow-up: } 1558 \text { participants had observed LDL-C measurements at } 36 \text { months, } 1375 \\
\text { completed follow-up of } 36 \text { months for the primary endpoint of CVD } \\
\text { Women: } 6769(25 \%) \\
\text { Mean age (SD), years: } 63 \text { (9) } \\
\text { History of CVD: } 27,564 \text { (100\%), not reported but inferred based on inclusion criteria } \\
\text { Participants with FH: NA } \\
\text { Inclusion criteria } \\
\text { - Men or women } 40-85 \text { years of age } \\
\text { - History of clinically evident CVD at high risk for a recurrent event } \\
\text { - Fasting LDL-C } \geq 70 \mathrm{mg} / \mathrm{dL} \text { ( } \geq 1.8 \mathrm{mmol} / \mathrm{L} \text { ) or non-HDL-C } \geq 100 \mathrm{mg} / \mathrm{dL}(>2.6 \mathrm{mmol} / \mathrm{L} \text { ) } \\
\text { - Fasting TGs } \leq 400 \mathrm{mg} / \mathrm{dL} \text { ( } 4.5 \mathrm{mmol} / \mathrm{L} \text { ) } \\
\text { Exclusion criteria } \\
\text { - NYHA class III or IV, or last known left ventricular ejection fraction }<30 \% \\
\text { - Uncontrolled hypertension } \\
\text { - Uncontrolled or recurrent ventricular tachycardia } \\
\text { - Untreated hyperthyroidism or hypothyroidism } \\
\text { - Homozygous FH } \\
\text { - Low-density lipoprotein or plasma apheresis }\end{array}$ \\
\hline
\end{tabular}

Interventions

Background therapy: statin therapy

Randomised therapy: evolocumab compared to placebo

Evolocumab dose: $140 \mathrm{mg} / 2$ weeks or to $420 \mathrm{mg} / 4$ weeks. Resulting in a 2-week equivalent dose of 140-210 mg

Outcomes

CVD defined as: CV death, myocardial infarction, stroke, hospitalisation for unstable angina, or coronary revascularisation 
FOURIER (Continued)

Notes Funded by Amgen

\section{Risk of bias}

\begin{tabular}{|c|c|c|}
\hline Bias & Authors' judgement & Support for judgement \\
\hline $\begin{array}{l}\text { Random sequence genera- } \\
\text { tion (selection bias) }\end{array}$ & Low risk & Central computerised system. \\
\hline $\begin{array}{l}\text { Allocation concealment } \\
\text { (selection bias) }\end{array}$ & Low risk & Central allocation. \\
\hline $\begin{array}{l}\text { Blinding of participants } \\
\text { and personnel (perfor- } \\
\text { mance bias) } \\
\text { All outcomes }\end{array}$ & Low risk & Both were blinded. \\
\hline $\begin{array}{l}\text { Blinding of outcome as- } \\
\text { sessment (detection bias) } \\
\text { All outcomes }\end{array}$ & Low risk & Central laboratory and blinded adjudication. \\
\hline $\begin{array}{l}\text { Incomplete outcome data } \\
\text { (attrition bias) } \\
\text { All outcomes }\end{array}$ & Low risk & $\begin{array}{l}27,564 \text { participants were randomised of whom } 39 \text { did not receive any treat- } \\
\text { ment. The number of participants available reduced considerably over time to } \\
\text { only } 1375 \text { participants remaining at study end. However, as reported, loss to } \\
\text { follow-up was only } 0.1 \% \text { and the decrease in number reflects different enrol- } \\
\text { ment times. }\end{array}$ \\
\hline $\begin{array}{l}\text { Selective reporting (re- } \\
\text { porting bias) }\end{array}$ & Low risk & Reported most endpoints. \\
\hline Other bias & Low risk & No concerns outside the assessed risk of bias domain./ \\
\hline
\end{tabular}

GAUSS-3

\section{Study characteristics}

Methods Type of RCT: 1:1 parallel-group, double-blind RCT (after a run-in phase)

Settings: outpatient care

Duration: 24 weeks (6 months)

Start and stop dates: February 2016 and August 2017

Participants Number of participants: 291 (in phase B, after the run-in phase), statin intolerant participants

\section{Number lost to follow-up: 2}

Women: 106 (49\%)

Mean age (SD), years: 59 (10)

History of CVD: unknown

Participants with FH: NA

Inclusion criteria 
GAUSS-3 (Continued)

- Men or women $18-80$ years of age

- Inability to tolerate atorvastatin $10 \mathrm{mg}$ and any other statin at any dose or, alternatively, $\geq 3$ statins, with 1 at the lowest mean daily starting dose and 2 other statins at any dose. The lowest mean starting dose was defined as rosuvastatin $5 \mathrm{mg}$, simvastatin $10 \mathrm{mg}$, pravastatin $40 \mathrm{mg}$, lovastatin 20 , fluvastatin $40 \mathrm{mg}$, or pitavastatin $2 \mathrm{mg}$

- For people with diagnosed CHD, lipid inclusion criteria required $L D L-C \geq 100 \mathrm{mg} / \mathrm{dL}$. People without $\mathrm{CHD}$ were required to have $\mathrm{LDL}-\mathrm{C} \geq 130 \mathrm{mg} / \mathrm{dL}$ with $\geq 2$ risk factors, $\geq 160 \mathrm{mg} / \mathrm{dL}$ with $\geq 1$ risk factors, or $\geq 190 \mathrm{mg} / \mathrm{dL}$ with 0 additional risk factors.

Exclusion criteria

- Myocardial infarction, unstable angina, coronary revascularisation, or stroke within 3 months before randomisation

- Personal or family history of hereditary muscular disorders

- Moderate-to-severe heart failure or uncontrolled cardiac arrhythmia

- Recently diagnosed or poorly controlled diabetes

- Hypertension or hyper/hypothyroidism

- Known active infection

- Major haematological, renal, hepatic, metabolic, gastrointestinal, or endocrine dysfunction

Interventions

Background therapy: none

Randomised therapy: evolocumab vs ezetimibe (10 mg)

Evolocumab dose: $420 \mathrm{mg} / 4$ weeks

\begin{tabular}{ll}
\hline Outcomes & CVD, all-cause mortality \\
\hline Notes & Funded by Amgen
\end{tabular}

\section{Risk of bias}

\begin{tabular}{lll}
\hline Bias & Authors' judgement & Support for judgement \\
\hline $\begin{array}{l}\text { Random sequence genera- } \\
\text { tion (selection bias) }\end{array}$ & Low risk & Central computerised system. \\
\hline $\begin{array}{l}\text { Allocation concealment } \\
\text { (selection bias) }\end{array}$ & Low risk & Central allocation. \\
\hline $\begin{array}{l}\text { Blinding of participants } \\
\begin{array}{l}\text { and personnel (perfor- } \\
\text { mance bias) } \\
\text { All outcomes }\end{array}\end{array}$ & Low risk & Both were blinded. \\
\hline
\end{tabular}

Blinding of outcome as-
sessment (detection bias) $\quad$ Low risk Central laboratory and blinded adjudication.

All outcomes

Incomplete outcome data $\quad$ Low risk 2 participants were lost to follow-up.
(attrition bias)

(attrition bias)
All outcomes

Selective reporting (re- Low risk Reported most endpoints.
porting bias)

Other bias Low risk No concerns outside the assessed risk of bias domains.


Settings: outpatient care

Duration: 76 weeks

Start and stop dates: April 2013 and July 2016

\section{Participants}

\section{Number of participants: 968}

Number lost to follow-up: 124 participants excluded from the primary analysis

Women: $269(28 \%)$

Mean age (SD), years: $59.8(9.2)$

History of CVD: 628 (65\%)

Participants with FH: unknown

Inclusion criteria

- Men or women aged $>18$ years

- Clinically indicated coronary angiogram, evidence of coronary disease

- Stable statin dose for $\geq 4$ weeks prior to screening

- LDL-C criteria met within 4 weeks of screening visit or, if applicable, at the end of lipid stabilisation period: $\mathrm{LDL}-\mathrm{C} \geq 80 \mathrm{mg} / \mathrm{dL}, \mathrm{OR} \mathrm{LDL}-\mathrm{C} \geq 60$ but $\leq 80 \mathrm{mg} / \mathrm{dL}$ in the presence of 1 major or 3 minor risk factors

- Major risk factors (1 required): non-coronary atherosclerotic vascular disease as evidenced by documented peripheral arterial disease, documented abdominal aortic aneurysm, or documented cerebrovascular disease; documented myocardial infarction or hospitalisation for unstable angina within the last 2 years; documented T2DM

- Minor risk factors (3 required): cigarette smoking (current); hypertension (blood pressure $\geq 140 / 90$ $\mathrm{mmHg}$ or current use of antihypertensive medications); low HDL-C (men: $<40 \mathrm{mg} / \mathrm{dL}$; women $<50 \mathrm{mg}$ / $\mathrm{dL}$ ); family history of premature $\mathrm{CHD}$ (first-degree male relative aged $<55$ years or first-degree female relative aged $<65$ years); age ( $m e n \geq 50$ years; women $\geq 55$ years); hs-CRP $\geq 2 \mathrm{mg}$

Exclusion criteria

- Clinically significant heart disease which, in the opinion of the principal investigator, is likely to require coronary bypass surgery, percutaneous coronary intervention, cardiac transplantation, surgical valve repair, replacement during the study, or a combination of these

- Heart failure of New York Heart Failure Association (NYHA) class III or IV or last known left ventricular ejection fraction $<30 \%$

- Coronary artery bypass surgery $<6$ week prior to the qualifying IVUS

- Cardiac arrhythmia within 3 months prior to randomisation that was not controlled by medication

- Uncontrolled hypertension at day 1 , defined as a resting systolic blood pressure $\geq 180 \mathrm{mmHg}$

- $\mathrm{TG}>400 \mathrm{mg} / \mathrm{dL}$ at screening

- Type 1 diabetes mellitus or poorly controlled T2DM (HbA1c 9\%) at screening

- TSH lower limit of normal or TSH $>1.5 \times$ ULN

- Estimated glomerular filtration rate $<30 \mathrm{~mL} /$ minute per $1.73 \mathrm{~m}^{2}$

- Aspartate aminotransferase or alanine aminotransferase $>2 \times$ ULN

- Creatine kinase $>3 \times$ ULN

- Use of cholesterylester transfer protein inhibition treatment within 12 months prior to randomisation

- Any prior use of PCSK9 inhibitor therapy 
- Consumption of any of the following drugs for more than 2 weeks in the last 3 months prior to LDL-C screening: systemic ciclosporin, systemic steroids, isotretinoin

- History of malignancy (except non-melanoma skin cancers, cervical in situ carcinoma, breast ductal carcinoma in situ, or stage 1 prostate carcinoma)

- Known major active infection, or major haematological, renal, metabolic, gastrointestinal, or endocrine dysfunction

- Baseline IVUS did not meet IVUS core laboratory technical standards

- Women could not be pregnant or breastfeeding. Premenopausal women must have been willing to use $\geq 1$ highly effective method of birth control during treatment and for an additional 15 weeks after end of treatment

Interventions

Background therapy: statin

Randomised therapy: evolocumab vs placebo.

Evolocumab dose: $140 \mathrm{mg} / 2$ week or to $420 \mathrm{mg} / 4$ weeks. Resulting in a 2-week equivalent dose of $140-210 \mathrm{mg}$

Outcomes

Notes Funded by Amgen

\section{Risk of bias}

\begin{tabular}{|c|c|c|}
\hline Bias & Authors' judgement & Support for judgement \\
\hline $\begin{array}{l}\text { Random sequence genera- } \\
\text { tion (selection bias) }\end{array}$ & Unclear risk & $\begin{array}{l}\text { Study did not describe this in detail. However, Amgen trials used interactive } \\
\text { voice-response system which was likely used here as well. }\end{array}$ \\
\hline $\begin{array}{l}\text { Allocation concealment } \\
\text { (selection bias) }\end{array}$ & Unclear risk & $\begin{array}{l}\text { Not reported. However, Amgen trials used interactive voice-response system } \\
\text { which was likely used here as well. }\end{array}$ \\
\hline $\begin{array}{l}\text { Blinding of participants } \\
\text { and personnel (perfor- } \\
\text { mance bias) } \\
\text { All outcomes }\end{array}$ & Low risk & $\begin{array}{l}\text { Described as double-blind. } \\
\text { Quote: "Technicians blinded to the treatment status of the patient and the } \\
\text { timing of each individual pullback will perform the } \\
\text { analysis." }\end{array}$ \\
\hline $\begin{array}{l}\text { Blinding of outcome as- } \\
\text { sessment (detection bias) } \\
\text { All outcomes }\end{array}$ & Unclear risk & $\begin{array}{l}\text { Quote: "The study includes adjudication of deaths and specific cardiovascular } \\
\text { events potential endpoints (PEPs) by an independent Clinical Events Commit- } \\
\text { tee (CEC) and formal review of the accumulating data by an independent Data } \\
\text { Monitoring Committee (DMC)." }\end{array}$ \\
\hline
\end{tabular}

Incomplete outcome data High risk

124/970 participants excluded from the primary analysis.

(attrition bias)

All outcomes

Selective reporting (re- Low risk Reported the usual endpoints.
porting bias)

Other bias Low risk No concerns outside the assessed risk of bias domains.

\section{Study characteristics}


ODYSSEY CHOICE II (Continued)

Methods

Type of RCT: 1:2 parallel group, double-blind RCT

Settings: outpatient care

Duration: 24 weeks

Start and stop dates: December 2013 and June 2017

\begin{tabular}{|c|c|}
\hline \multirow[t]{7}{*}{ Participants } & Number of participants: 233 \\
\hline & Number lost to follow-up: NA \\
\hline & Women: 103 (44\%) \\
\hline & Mean age (SD): $63(10)$ \\
\hline & History of CVD: NA \\
\hline & FH participants: $29(12 \%)$ \\
\hline & $\begin{array}{l}\text { Participants with primary hypercholesterolaemia (heFH or non-FH) with high CV risk with muscle-relat- } \\
\text { ed statin intolerance, or moderate CV risk without muscle-related statin intolerance. }\end{array}$ \\
\hline \multirow[t]{3}{*}{ Interventions } & Background therapy: ezetimibe, fenofibrate, or diet alone. \\
\hline & Randomised therapy: alirocumab vs placebo \\
\hline & $\begin{array}{l}\text { Alirocumab dose: } 24 \text { weeks of } 75 \mathrm{mg} \text { every } 2 \text { weeks or } 150 \mathrm{mg} \text { every } 4 \text { weeks. At } 12 \text { weeks, participants } \\
\text { could switch to } 150 \mathrm{mg} \text { every } 2 \text { weeks. Resulting in a 2-week equivalent dose of } 75-150 \mathrm{mg} \text {. }\end{array}$ \\
\hline Outcomes & All-cause mortality \\
\hline Notes & $\begin{array}{l}\text { - All results based on an abstract } \\
\text { - Results presented as alirocumab vs placebo } \\
\text { - NCT0203879 } \\
\text { - Funded by Sanofi and Regeneron }\end{array}$ \\
\hline
\end{tabular}

\section{Risk of bias}

\begin{tabular}{|c|c|c|}
\hline Bias & Authors' judgement & Support for judgement \\
\hline $\begin{array}{l}\text { Random sequence genera- } \\
\text { tion (selection bias) }\end{array}$ & Unclear risk & Not reported. \\
\hline $\begin{array}{l}\text { Allocation concealment } \\
\text { (selection bias) }\end{array}$ & Unclear risk & Not reported. \\
\hline $\begin{array}{l}\text { Blinding of participants } \\
\text { and personnel (perfor- } \\
\text { mance bias) } \\
\text { All outcomes }\end{array}$ & Low risk & Placebo-blinded trial. \\
\hline $\begin{array}{l}\text { Blinding of outcome as- } \\
\text { sessment (detection bias) } \\
\text { All outcomes }\end{array}$ & Low risk & Clinical Events Committee. \\
\hline $\begin{array}{l}\text { Incomplete outcome data } \\
\text { (attrition bias) } \\
\text { All outcomes }\end{array}$ & Unclear risk & No details provided on missing data. \\
\hline
\end{tabular}


ODYSSEY CHOICE II (Continued)

Selective reporting (re- Low risk Reported protocol-defined endpoints. porting bias)

Other bias

Low risk

No concerns outside the assessed risk of bias domains.

\section{ODYSSEY ALTERNATIVE}

\section{Study characteristics}

\begin{tabular}{|c|c|}
\hline Methods & $\begin{array}{l}\text { Type of RCT: 1:1 parallel-group RCT, with stratification for CVD history } \\
\text { Settings: outpatient care } \\
\text { Duration: } 24 \text { weeks } \\
\text { Start and stop dates: September } 2012 \text { and September } 2016\end{array}$ \\
\hline Participants & $\begin{array}{l}\text { Number of participants: } 251 \text { (excluding } 63 \text { participants in an atorvastatin rechallenge arm) } \\
\text { Number lost to follow-up: } 80 \\
\text { Women: } 114(45 \%) \\
\text { Mean age (SD), years: } 63(10) \\
\text { History of CVD: } 115(46 \%) \\
\text { FH participants: } 38 \text { (15\%) } \\
\text { Participants with primary hypercholesterolaemia and moderate, high, or very high CV risk, who were } \\
\text { intolerant to statins } \\
377 \text { participants with a history of statin intolerance, and of moderate, high, or very high CV risk. Mod- } \\
\text { erate CV risk defined as SCORE risk of } \geq 1 \% \text { but }<5 \% \text {; high risk defined as score risk } \geq 5 \% \text {, or moderate } \\
\text { chronic kidney disease, diabetes without target organ damage heFH; very high risk defined as history } \\
\text { of documented CHD, ischaemic stroke, peripheral artery disease, TIA, abdominal aortic aneurysm, or } \\
\text { carotid artery stent procedure, or carotid endarterectomy or carotid artery stent procedure, or renal } \\
\text { artery stenosis or renal artery stent procedure or diabetes with target organ damage }\end{array}$ \\
\hline Interventions & $\begin{array}{l}\text { Background therapy: National Cholesterol Education Program Adult Treatment Panel III therapeutic } \\
\text { lifestyle changes diet. Participants were allowed to continue to use bile acid, nicotinic acid, fenofibrate, } \\
\text { or mega-3 acid } \\
\text { Randomised therapy: alirocumab and placebo vs ezetimibe } 10 \mathrm{mg} \text { daily or atorvastatin } 20 \mathrm{mg} \text { and } \\
\text { placebo } \\
\text { Alirocumab dose: } 24 \text { weeks } 75 \mathrm{mg} \text { every } 2 \text { weeks, with uptitration to } 150 \mathrm{mg} \text { every } 2 \text { weeks at week } 12 \text {. } \\
\text { Resulting in a 2-week equivalent dose of } 75-150 \mathrm{mg}\end{array}$ \\
\hline Outcomes & MACE, all-cause mortality \\
\hline Notes & $\begin{array}{l}\text { - Atorvastatin arm was included as a rechallenge experiment. Main analysis focuses on alirocumab vs } \\
\text { ezetimibe (151 participants) } \\
\text { - LDL-C calculated using Friedewald formula } \\
\text { - NCT01709513 } \\
\text { - Funded by Sanofi and Regeneron }\end{array}$ \\
\hline
\end{tabular}

Risk of bias

PCSK9 monoclonal antibodies for the primary and secondary prevention of cardiovascular disease (Review) 
ODYSSEY ALTERNATIVE (Continued)

\begin{tabular}{|c|c|c|}
\hline Bias & Authors' judgement & Support for judgement \\
\hline $\begin{array}{l}\text { Random sequence genera- } \\
\text { tion (selection bias) }\end{array}$ & Unclear risk & Not described. \\
\hline $\begin{array}{l}\text { Allocation concealment } \\
\text { (selection bias) }\end{array}$ & Low risk & Permuted-block design and central allocation. \\
\hline $\begin{array}{l}\text { Blinding of participants } \\
\text { and personnel (perfor- } \\
\text { mance bias) } \\
\text { All outcomes }\end{array}$ & Unclear risk & $\begin{array}{l}\text { Placebo-controlled, participants self-administered. Unclear if staff were also } \\
\text { blinded. }\end{array}$ \\
\hline $\begin{array}{l}\text { Blinding of outcome as- } \\
\text { sessment (detection bias) } \\
\text { All outcomes }\end{array}$ & Low risk & Lipid parameters assessed at central blinded laboratory. \\
\hline $\begin{array}{l}\text { Incomplete outcome data } \\
\text { (attrition bias) } \\
\text { All outcomes }\end{array}$ & High risk & $\begin{array}{l}36(28.6 \%) \text { participants in the alirocumab arm had missing lipid measure- } \\
\text { ments compared with } 44(36.1 \%) \text { in the ezetimibe arm. Potentially, these } \\
\text { 'missing' participants simply did not make the required follow-up time ( } 24 \\
\text { weeks) owing to late enrolment; without specific description of the reason for } \\
\text { these lower numbers, some concern is warranted. }\end{array}$ \\
\hline $\begin{array}{l}\text { Selective reporting (re- } \\
\text { porting bias) }\end{array}$ & Low risk & Reported results showed agreement with ClinicalTrials.gov. \\
\hline Other bias & Low risk & No concerns outside the assessed risk of bias domains. \\
\hline
\end{tabular}

\section{ODYSSEY CHOICE I}

\section{Study characteristics}

\begin{tabular}{ll}
\hline Methods & Type of RCT: $1: 2$ parallel-group, double-blind, stratified RCT \\
Settings: outpatient care & Duration: 24 weeks \\
& Start and stop dates: October 2013 and May 2015 \\
\hline Number of participants: 803 \\
Number lost to follow-up: NA \\
Women: 341 (42\%) \\
Mean age (SD), years: 60 (10) \\
History of CVD: NA \\
Participants with FH: 45 (6\%) \\
Participants with poorly controlled hypercholesterolaemia and moderate CV risk with or without mus- \\
cle-related statin intolerance, or with high CV risk receiving maximally tolerated dose. No definition of \\
poorly controlled or moderate/high CV risk was provided.
\end{tabular}

Interventions

Background therapy: statin therapy 
Randomised therapy: alirocumab vs placebo. At 12 weeks, participants could switch to $150 \mathrm{mg}$ every 2 weeks

Alirocumab dose: 48 weeks 75 mg every 2 weeks or 300 mg every 4 weeks. Resulting in a 2-week equivalent dose of 75-150 mg. Treatment was allocated stratified on statin use or not

\begin{tabular}{ll}
\hline Outcomes & Adverse events, all-cause mortality \\
\hline Notes & - All results based on an abstract \\
& - Results presented as alirocumab vs placebo \\
& - NCT01926782 \\
& - Funded by Sanofi and Regeneron \\
\hline
\end{tabular}

\section{Risk of bias}

\begin{tabular}{|c|c|c|}
\hline Bias & Authors' judgement & Support for judgement \\
\hline $\begin{array}{l}\text { Random sequence genera- } \\
\text { tion (selection bias) }\end{array}$ & Unclear risk & Not reported. \\
\hline $\begin{array}{l}\text { Allocation concealment } \\
\text { (selection bias) }\end{array}$ & Unclear risk & Not reported. \\
\hline $\begin{array}{l}\text { Blinding of participants } \\
\text { and personnel (perfor- } \\
\text { mance bias) } \\
\text { All outcomes }\end{array}$ & Low risk & Placebo controlled trial. \\
\hline $\begin{array}{l}\text { Blinding of outcome as- } \\
\text { sessment (detection bias) } \\
\text { All outcomes }\end{array}$ & Low risk & Clinical events committee and blinded assessment using a central laboratory. \\
\hline $\begin{array}{l}\text { Incomplete outcome data } \\
\text { (attrition bias) } \\
\text { All outcomes }\end{array}$ & Unclear risk & No details of missing data provided. \\
\hline $\begin{array}{l}\text { Selective reporting (re- } \\
\text { porting bias) }\end{array}$ & Low risk & Reported protocol-defined endpoints. \\
\hline Other bias & Low risk & No concerns outside the assessed risk of bias domains. \\
\hline
\end{tabular}

\section{ODYSSEY COMBO I}

\section{Study characteristics}

Methods

Type of RCT: 1:2 parallel-group, double-blind, stratified RCT

Settings: outpatient care

Duration: 52 weeks

Start and stop dates: July 2012 and April 2014
Number of participants: 316

Number lost to follow-up: 30 
ODYSSEY COMBO I (Continued)

Women: 108 (34\%)

Mean age (SD), years: 63 (9)

History of CVD: 247 (78\%)

FH participants: 0

Participants with hypercholesterolaemia (LDL-C $\geq 70 \mathrm{mg} / \mathrm{dL}$ ) and established CVD or LDL-C $100 \mathrm{mg} / \mathrm{dL}$ and CHD risk equivalents (e.g. chronic kidney disease) and on a maximally tolerated dose of statin, with possible addition of other LLTs

\begin{tabular}{ll} 
Interventions & Background therapy: both add-on to maximal tolerated dose of statin \\
& Randomised therapy: alirocumab vs placebo \\
& $\begin{array}{l}\text { Alirocumab dose: } 104 \text { weeks of } 75 \mathrm{mg} \text { every } 2 \text { weeks, with uptitration to } 150 \mathrm{mg} \text { every } 2 \text { weeks at week } \\
12 \text { resulting in a } 2 \text {-week equivalent dose of } 75-150 \mathrm{mg}\end{array}$ \\
\hline Outcomes & CVD, all-cause mortality \\
\hline Notes & - LDL-C calculated using Friedewald formula, or if TGs $>400 \mathrm{mg} / \mathrm{dL}$ via beta quantification method \\
& - FCT01644175 \\
\hline
\end{tabular}

\section{Risk of bias}

\begin{tabular}{lll}
\hline Bias & Authors' judgement & Support for judgement \\
\hline $\begin{array}{ll}\text { Random sequence genera- } \\
\text { tion (selection bias) }\end{array}$ & Unclear risk & $\begin{array}{l}\text { Did not mention randomisation but presumably similar as COMBO II: used an } \\
\text { interactive voice-response system. }\end{array}$ \\
\hline
\end{tabular}

\begin{tabular}{lll}
\hline $\begin{array}{l}\text { Allocation concealment } \\
\text { (selection bias) }\end{array}$ & Unclear risk & Did not describe allocation concealment. \\
\hline $\begin{array}{l}\text { Blinding of participants } \\
\text { and personnel (perfor- } \\
\text { mance bias) }\end{array}$ & Low risk & Both blinded. \\
All outcomes & \\
\hline
\end{tabular}

Blinding of outcome as-
sessment (detection bias) $\quad$ Low risk $\quad$ Clinical events committee and central laboratory.

All outcomes

\begin{tabular}{|c|c|c|}
\hline $\begin{array}{l}\text { Incomplete outcome data } \\
\text { (attrition bias) } \\
\text { All outcomes }\end{array}$ & High risk & $\begin{array}{l}20(9.57 \%) \text { participants in the alirocumab arm had missing lipid measure- } \\
\text { ments compared with } 10(9.34 \%) \text { in the comparator arm. Potentially, these } \\
\text { 'missing' participants simply did not make the required follow-up time ( } 24 \\
\text { weeks) owing to late enrolment; however, without specific description of the } \\
\text { reasons for these lower numbers, some concern is warranted. }\end{array}$ \\
\hline
\end{tabular}

Selective reporting (re- Low risk $\quad$ Reported protocol-defined endpoints.
porting bias)

\begin{tabular}{ll}
\hline Other bias $\quad$ Low risk $\quad$ No concerns outside the assessed risk of bias domains. \\
\hline
\end{tabular}




\section{ODYSSEY COMBO II}

\section{Study characteristics}

\begin{tabular}{|c|c|}
\hline Methods & $\begin{array}{l}\text { Type of RCT: 2:1 parallel-group, double-blind, stratified, permuted-block RCT } \\
\text { Settings: outpatient care } \\
\text { Duration: } 104 \text { weeks } \\
\text { Start and stop dates: August } 2012 \text { and July } 2015\end{array}$ \\
\hline Participants & $\begin{array}{l}\text { Number of participants: } 720 \\
\text { Number lost to follow-up: } 13 \\
\text { Women: } 190(26 \%) \\
\text { Mean age (SD), years: } 62 \text { (9) } \\
\text { History of CVD: } 649(90 \%) \\
\text { FH participants: } 0 \\
\text { Participants with hypercholesterolaemia (not defined) and established CHD or CHD risk equivalents (is- } \\
\text { chaemic stroke, peripheral artery disease, moderate chronic kidney disease, or diabetes mellitus plus } \geq \\
2 \text { additional risk factors) and on a maximally tolerated dose of statin, without addition of other LLTs }\end{array}$ \\
\hline Interventions & $\begin{array}{l}\text { Background therapy: add-on to maximal tolerated dose of statin } \\
\text { Randomised therapy: alirocumab and ezetimibe placebo vs ezetimibe } 10 \mathrm{mg} \text { daily and placebo } \\
\text { Alirocumab: } 104 \text { weeks of } 75 \mathrm{mg} \text { every } 2 \text { weeks, with uptitration to } 150 \mathrm{mg} \text { every } 2 \text { weeks at week 12, } \\
\text { resulting in a 2-week equivalent dose of } 75-150 \mathrm{mg}\end{array}$ \\
\hline Outcomes & CVD, all-cause mortality \\
\hline Notes & $\begin{array}{l}\text { - LDL-C calculated using Friedewald formula, or if TGs exceeded } 400 \mathrm{mg} / \mathrm{dL} \text { via beta quantification } \\
\text { method } \\
\text { - NCT01644188 } \\
\text { - Funded by Sanofi and Regeneron }\end{array}$ \\
\hline
\end{tabular}

\section{Risk of bias}

\begin{tabular}{lll}
\hline Bias & Authors' judgement & Support for judgement \\
\hline $\begin{array}{l}\text { Random sequence genera- } \\
\text { tion (selection bias) }\end{array}$ & Low risk & Used interactive voice-response system. \\
\hline $\begin{array}{l}\text { Allocation concealment } \\
\text { (selection bias) }\end{array}$ & Low risk & Permuted blocks. \\
\hline $\begin{array}{l}\text { Blinding of participants } \\
\text { and personnel (perfor- } \\
\text { mance bias) }\end{array}$ & Low risk & Both were blinded. \\
$\begin{array}{l}\text { All outcomes } \\
\text { Blinding of outcome as- } \\
\text { sessment (detection bias) } \\
\begin{array}{l}\text { All outcomes } \\
\text { L }\end{array}\end{array}$ & Low risk & Clinical events committee and central laboratory. \\
\hline
\end{tabular}




\section{ODYSSEY COMBO II (Continued)}

Incomplete outcome data Low risk (attrition bias)

All outcomes
$12(2.51 \%)$ participants in the alirocumab arm had missing lipid measurements compared with $1(0.41)$ in the comparator arm. Additionally, mixed-effects (ANCOVA) models were used.

Selective reporting (re- Low risk Reported protocol-defined endpoints.

porting bias)

Other bias Low risk No concerns outside the assessed risk of bias domains.

\section{Study characteristics}

Methods

Type of RCT: 1:2 parallel-group, open-label, stratified RCT

Settings: outpatient care

Duration: 24 weeks

Start and stop dates: December 2015 and May 2018

\section{Participants}

Number of participants: 413

Number lost to follow-up: 4

Women: $197(48 \%)$

Mean age (SD), years: $63.2(9.1)$

History of CVD: $142(34 \%)$

FH participants: NA

People with T2DM and mixed dyslipidaemia at high CV risk with non-HDL-C not adequately controlled with maximally tolerated statin therapy.

Inclusion criteria

- Aged $\geq 18$ years or legal age of majority at screening visit, whichever greater

- Atherosclerotic CVD (including CHD, documented PAD or previous ischaemic stroke) or $\geq 1$ additional $\mathrm{CV}$ risk factor, or a combination

- Stable antihyperglycaemic treatment (including insulin)

- Stable, maximally tolerated dose/regimen of statin for $\geq 4$ weeks prior to screening without other LLT

- Non-HDL-C $\geq 100 \mathrm{mg} / \mathrm{dL}(2.59 \mathrm{mmol} / \mathrm{L})$

- $\mathrm{TG} \geq 150 \mathrm{mg} / \mathrm{dL}$ and $<500 \mathrm{mg} / \mathrm{dL}$

- No weight variation $>5 \mathrm{~kg}$ within 3 months

Exclusion criteria

- $\mathrm{HbA} 1 \mathrm{c} \geq 9 \%$

- Use of any LLT (other than statin) or over-the-counter product/nutraceuticals known to impact lipids within 4 weeks prior to screening

- $\mathrm{BMI}>45 \mathrm{~kg} / \mathrm{m}^{2}$

- Alcohol consumption $>2$ standard alcoholic drinks/day

Interventions

Background therapy: usual care (including maximally tolerated statins or non-statin therapies)

Randomised therapy: alirocumab + usual care vs usual care only 
ODYSSEY DM-DYSLIPIDEMIA (Continued)

Alirocumab dose: $75-150 \mathrm{mg}$ per 2 weeks

\begin{tabular}{ll}
\hline Outcomes & T2DM, all-cause mortality \\
\hline Notes & Funded by Sanofi and Regeneron \\
\hline
\end{tabular}

\title{
Risk of bias
}

\begin{tabular}{|c|c|c|}
\hline Bias & Authors' judgement & Support for judgement \\
\hline $\begin{array}{l}\text { Random sequence genera- } \\
\text { tion (selection bias) }\end{array}$ & Low risk & $\begin{array}{l}\text { Centralised treatment allocation system (interactive voice- or web-response } \\
\text { system, depending on the study site preference). }\end{array}$ \\
\hline $\begin{array}{l}\text { Allocation concealment } \\
\text { (selection bias) }\end{array}$ & Low risk & Central allocation. \\
\hline $\begin{array}{l}\text { Blinding of participants } \\
\text { and personnel (perfor- } \\
\text { mance bias) } \\
\text { All outcomes }\end{array}$ & High risk & Participants not blinded. \\
\hline $\begin{array}{l}\text { Blinding of outcome as- } \\
\text { sessment (detection bias) } \\
\text { All outcomes }\end{array}$ & Low risk & Endpoint adjudication blinded. \\
\hline $\begin{array}{l}\text { Incomplete outcome data } \\
\text { (attrition bias) } \\
\text { All outcomes }\end{array}$ & Low risk & 4/413 participants lost to follow-up. \\
\hline $\begin{array}{l}\text { Selective reporting (re- } \\
\text { porting bias) }\end{array}$ & Low risk & Reported usual endpoints. \\
\hline Other bias & Low risk & No concerns outside the assessed risk of bias domains. \\
\hline
\end{tabular}

\section{ODYSSEY DM-INSULIN}

\section{Study characteristics}

Methods Type of RCT: 1:2 parallel-group, stratified RCT

Settings: outpatient care

Duration: 24 weeks

Start and stop dates: October 2015 and May 2018

\section{Participants}

\author{
Number of participants: 517 \\ Number lost to follow-up: 14 \\ Women: 232 (45\%) \\ Mean age (SD), years: 63.7 (9.1) \\ History of CVD: 193 (37\%) \\ FH participants: NA
}


ODYSSEY DM-INSULIN (Continued)

Study population comprised people with insulin-treated T2DM or type 1 diabetes and established atherosclerotic CVD or $\geq 1$ additional CV risk factor (or a combination), who had LDL-C $\geq 1.8 \mathrm{mmol} / \mathrm{L}(\geq 70$ $\mathrm{mg} / \mathrm{dL}$ ) despite stable maximally tolerated doses of statin with or without other LLTs. People with statin intolerance (therefore not taking statins) were also eligible for enrolment.

Interventions Background therapy: stable diet for glucose and lipid management, and received treatment for diabetes in accordance with local/regional SOC

Randomised therapy: alirocumab vs placebo

Alirocumab dose: $75-150 \mathrm{mg}$ per 2 weeks

\begin{tabular}{ll}
\hline Outcomes & All-cause mortality \\
\hline Notes & Funded by Sanofi and Regeneron \\
\hline
\end{tabular}

\section{Risk of bias}

\begin{tabular}{|c|c|c|}
\hline Bias & Authors' judgement & Support for judgement \\
\hline $\begin{array}{l}\text { Random sequence genera- } \\
\text { tion (selection bias) }\end{array}$ & Low risk & $\begin{array}{l}\text { Quote: "At randomization, treatment kit numbers were allocated according } \\
\text { to a centralized treatment allocation system (either an interactive voice-re- } \\
\text { sponse or web-response system, depending on the study site)." }\end{array}$ \\
\hline $\begin{array}{l}\text { Allocation concealment } \\
\text { (selection bias) }\end{array}$ & Low risk & Placebo controlled. \\
\hline $\begin{array}{l}\text { Blinding of participants } \\
\text { and personnel (perfor- } \\
\text { mance bias) } \\
\text { All outcomes }\end{array}$ & Low risk & $\begin{array}{l}\text { Quote: "Study participants, principal investigators and study-site personnel } \\
\text { are blinded to all randomization assignments throughout } \\
\text { the duration of the study." }\end{array}$ \\
\hline $\begin{array}{l}\text { Blinding of outcome as- } \\
\text { sessment (detection bias) } \\
\text { All outcomes }\end{array}$ & Low risk & Independent committee. \\
\hline $\begin{array}{l}\text { Incomplete outcome data } \\
\text { (attrition bias) } \\
\text { All outcomes }\end{array}$ & Low risk & 14/517 participants lost to follow-up. \\
\hline $\begin{array}{l}\text { Selective reporting (re- } \\
\text { porting bias) }\end{array}$ & Low risk & Reported usual endpoints. \\
\hline Other bias & Low risk & No concerns outside the assessed risk of bias domains. \\
\hline
\end{tabular}

\section{ODYSSEY FH I}

\section{Study characteristics}

Methods Type of RCT: 2:1 parallel-group, double-blind, stratified RCT

Settings: outpatient care

Duration: 78 weeks

Start and stop dates: July 2012 and December 2014 
ODYSSEY FH I (Continued)

Participants
Number of participants: 486

Number lost to follow-up: 1

Women: $212(44 \%)$

Mean age (SD), years: 52 (13)

History of CVD: 225 (46\%)

Participants with FH: 485 (100\%)

Participants with heFH on a maximally tolerated dose of statin with LDL-C $\geq 70 \mathrm{mg} / \mathrm{dL}$ or $\geq 100 \mathrm{mg} / \mathrm{dL}$, depending on CV risk

Background therapy: add-on to maximal tolerated dose of statin and possible addition of other LLTs

Randomised therapy: alirocumab vs placebo

Alirocumab dose: 78 weeks of $75 \mathrm{mg}$ every 2 weeks, with possible uptitration to $150 \mathrm{mg}$ every 2 weeks at week 12. Resulting in a 2-week equivalent dose of 75-150 mg

\begin{tabular}{ll}
\hline Outcomes & CVD, adverse events, all-cause mortality \\
\hline Notes & - LDL-C calculated using Friedewald formula, or if TGs $>400 \mathrm{mg} / \mathrm{dL}$ via beta quantification method \\
& - NCT01623155 \\
& - Funded by Sanofi and Regeneron
\end{tabular}

\section{Risk of bias}

\begin{tabular}{|c|c|c|}
\hline Bias & Authors' judgement & Support for judgement \\
\hline $\begin{array}{l}\text { Random sequence genera- } \\
\text { tion (selection bias) }\end{array}$ & Low risk & $\begin{array}{l}\text { Centralised interactive voice-response system or interactive web-response } \\
\text { system. }\end{array}$ \\
\hline $\begin{array}{l}\text { Allocation concealment } \\
\text { (selection bias) }\end{array}$ & Low risk & Central allocation. \\
\hline $\begin{array}{l}\text { Blinding of participants } \\
\text { and personnel (perfor- } \\
\text { mance bias) } \\
\text { All outcomes }\end{array}$ & Low risk & Both blinded. \\
\hline $\begin{array}{l}\text { Blinding of outcome as- } \\
\text { sessment (detection bias) } \\
\text { All outcomes }\end{array}$ & Low risk & Endpoint adjudication was blinded and central laboratory. \\
\hline $\begin{array}{l}\text { Incomplete outcome data } \\
\text { (attrition bias) } \\
\text { All outcomes }\end{array}$ & Low risk & $\begin{array}{l}1(0.31 \%) \text { participant in the alirocumab arm had missing lipid measurements } \\
\text { compared with } 0 \text { in the comparator arm. Additionally, mixed-effects (ANCOVA) } \\
\text { models were used. }\end{array}$ \\
\hline $\begin{array}{l}\text { Selective reporting (re- } \\
\text { porting bias) }\end{array}$ & Low risk & Reported protocol-defined endpoints. \\
\hline Other bias & Low risk & No concerns outside the assessed risk of bias domains. \\
\hline
\end{tabular}


ODYSSEY FH II

\section{Study characteristics}

Type of RCT: 2:1 parallel-group, double-blind, stratified RCT
Settings: outpatient care
Duration: 52 weeks
Start and stop dates: December 2012 and January 2015
Number of participants: 249
Number lost to follow-up: 2
Pomen: 118 (47\%)
Mean age (SD), years: 53.2 (17.2)
History of CVD: 89 (36\%)
Participants with FH: 249 (100\%)
Participants with heFH not adequately controlled with a maximally tolerated daily dose of statin with
or without the other LMT, at a stable dose before the screening visit

\begin{tabular}{l} 
Bnterventions \\
Rackground therapy: add-on to maximal tolerated dose of statin and possible addition of other LLTs \\
Randomised therapy: alirocumab vs placebo \\
Alirocumab dose: 78 weeks $75 \mathrm{mg}$ every 2 weeks, with possible uptitration to $150 \mathrm{mg}$ every 2 weeks at \\
week 12. Resulting in a 2-week equivalent dose of $75-150 \mathrm{mg}$ \\
\hline CVD, adverse events, all-cause mortality \\
\hline Outcomes \\
Dotes \\
- LDL-C calculated using Friedewald formula, or if TGs $>400 \mathrm{mg} / \mathrm{dL}$ via beta quantification method \\
- Subgroup analyses are provided for FH I and FH II combined \\
- Funded by Sanofi and Regeneron
\end{tabular}

\section{Risk of bias}

\begin{tabular}{|c|c|c|}
\hline Bias & Authors' judgement & Support for judgement \\
\hline $\begin{array}{l}\text { Random sequence genera- } \\
\text { tion (selection bias) }\end{array}$ & Low risk & $\begin{array}{l}\text { Centralised interactive voice-response system or interactive web-response } \\
\text { system. }\end{array}$ \\
\hline $\begin{array}{l}\text { Allocation concealment } \\
\text { (selection bias) }\end{array}$ & Low risk & Central allocation. \\
\hline $\begin{array}{l}\text { Blinding of participants } \\
\text { and personnel (perfor- } \\
\text { mance bias) } \\
\text { All outcomes }\end{array}$ & Low risk & Both blinded. \\
\hline $\begin{array}{l}\text { Blinding of outcome as- } \\
\text { sessment (detection bias) } \\
\text { All outcomes }\end{array}$ & Low risk & Endpoint adjudication was blinded and central laboratory. \\
\hline
\end{tabular}




\section{ODYSSEY FH II (Continued)}

$\begin{array}{ll}\begin{array}{l}\text { Incomplete outcome data } \\ \text { (attrition bias) }\end{array} & \begin{array}{l}1(0.60 \%) \text { portion of the alirocumab arm had missing lipid measurements com- } \\ \text { pared with } 1(1.22 \%) \text { participant in the comparator arm. Additionally, mixed- } \\ \text { All outcomes }\end{array} \\ \text { effects (ANCOVA) models were used. }\end{array}$

\begin{tabular}{lll}
\hline $\begin{array}{l}\text { Selective reporting (re- } \\
\text { porting bias) }\end{array}$ & Low risk & Reported protocol-defined endpoints. \\
\hline Other bias & Low risk & No concerns outside the assessed risk of bias domains. \\
\hline
\end{tabular}

\section{ODYSSEY HIGH FH}

\section{Study characteristics}

\begin{tabular}{|c|c|}
\hline Methods & $\begin{array}{l}\text { Type of RCT: 2:1 parallel-group, double-blind, stratified RCT } \\
\text { Settings: outpatient care } \\
\text { Duration: } 78 \text { weeks } \\
\text { Start and stop dates: December } 2012 \text { and January } 2015\end{array}$ \\
\hline Participants & $\begin{array}{l}\text { Number of participants: } 107 \\
\text { Number lost to follow-up: } 1 \\
\text { Women: NA } \\
\text { Mean age (SD), years: NA } \\
\text { History of CVD: } 64 \text { (60\%) } \\
\text { Participants with FH: } 107 \text { (100\%) } \\
\text { Participants with heFH on a maximally tolerated dose of statin with LDL-C } \geq 160 \mathrm{mg} / \mathrm{dL}\end{array}$ \\
\hline Interventions & $\begin{array}{l}\text { Background therapy: both add-on to maximal tolerated dose of statin and possible addition of other } \\
\text { LLTs } \\
\text { Randomised therapy: alirocumab vs placebo } \\
\text { Alirocumab dose: } 78 \text { weeks of } 150 \mathrm{mg} \text { every } 2 \text { weeks }\end{array}$ \\
\hline Outcomes & CVD, adverse events, all-cause mortality \\
\hline Notes & $\begin{array}{l}\text { - LDL-C calculated using Friedewald formula } \\
\text { - Reported influenza } \\
\text { - Subgroup analyses are provided for FH I and FH II combined } \\
\text { - NCT01617655 } \\
\text { - Funded by Sanofi and Regeneron }\end{array}$ \\
\hline
\end{tabular}

\section{Risk of bias}

\begin{tabular}{lll}
\hline Bias & Authors' judgement & Support for judgement \\
\hline $\begin{array}{l}\text { Random sequence genera- } \\
\text { tion (selection bias) }\end{array}$ & Low risk & $\begin{array}{l}\text { Centralised interactive voice-response system or interactive web-response } \\
\text { system. }\end{array}$ \\
\hline
\end{tabular}




\section{ODYSSEY HIGH FH (Continued)}

\begin{tabular}{lll}
$\begin{array}{l}\text { Allocation concealment } \\
\text { (selection bias) }\end{array}$ & Low risk & Central allocation. \\
\hline $\begin{array}{l}\text { Blinding of participants } \\
\text { and personnel (perfor- } \\
\text { mance bias) }\end{array}$ & Low risk & Both blinded. \\
All outcomes &
\end{tabular}

\begin{tabular}{lll}
\hline $\begin{array}{l}\text { Blinding of outcome as- } \\
\text { sessment (detection bias) } \\
\text { All outcomes }\end{array}$ & Low risk & Endpoint adjudication was blinded and central laboratory. \\
\hline $\begin{array}{l}\text { Incomplete outcome data } \\
\begin{array}{l}\text { (attrition bias) } \\
\text { All outcomes }\end{array}\end{array}$ & Low risk & $\begin{array}{l}1(1.38 \%) \text { participant in the alirocumab arm had missing lipid measurements } \\
\text { compared with } 0 \text { in the comparator arm. Additionally, mixed-effects (ANCOVA) } \\
\text { models were used. }\end{array}$ \\
\hline
\end{tabular}

\begin{tabular}{lll}
\hline $\begin{array}{l}\text { Selective reporting (re- } \\
\text { porting bias) }\end{array}$ & Low risk & Reported protocol-defined endpoints. \\
\hline Other bias & Low risk & No concerns outside the assessed risk of bias domains. \\
\hline
\end{tabular}

\section{ODYSSEY JAPAN}

\section{Study characteristics}

Methods Type of RCT: $2: 1$ parallel-group, double-blind, stratified RCT

Settings: outpatient care

Duration: 52 weeks

Start and stop dates: March 2014 and September 2015

\begin{tabular}{ll}
\hline Participants & Number of participants: 216 \\
& Number lost to follow-up: 1 patient excluded from the primary analysis \\
Women: $85(39 \%)$ & \\
Mean age (SD), years: $60.8(9.5)$ & History of CVD: 216 (100\%) \\
& Participants with FH: NA \\
& $\begin{array}{l}\text { People with heFH, non-FH at high CV risk with coronary disease, or classified as category III were en- } \\
\text { rolled. }\end{array}$ \\
\hline Bnterventions & Background therapy: statin and other LLT \\
Randomised therapy: alirocumab vs placebo \\
Alirocumab dose: 75 mg every 2 weeks \\
\hline CVD, all-cause mortality \\
\hline Notes
\end{tabular}


ODYSSEY JAPAN (Continued)

Risk of bias

\begin{tabular}{|c|c|c|}
\hline Bias & Authors' judgement & Support for judgement \\
\hline $\begin{array}{l}\text { Random sequence genera- } \\
\text { tion (selection bias) }\end{array}$ & Unclear risk & Not reported. \\
\hline $\begin{array}{l}\text { Allocation concealment } \\
\text { (selection bias) }\end{array}$ & Unclear risk & Not reported. \\
\hline $\begin{array}{l}\text { Blinding of participants } \\
\text { and personnel (perfor- } \\
\text { mance bias) } \\
\text { All outcomes }\end{array}$ & Low risk & Placebo controlled. \\
\hline $\begin{array}{l}\text { Blinding of outcome as- } \\
\text { sessment (detection bias) } \\
\text { All outcomes }\end{array}$ & Low risk & Endpoint committee. \\
\hline $\begin{array}{l}\text { Incomplete outcome data } \\
\text { (attrition bias) } \\
\text { All outcomes }\end{array}$ & Low risk & 1 patient was excluded from the primary analysis. \\
\hline $\begin{array}{l}\text { Selective reporting (re- } \\
\text { porting bias) }\end{array}$ & Low risk & Reported protocol-endpoints. \\
\hline Other bias & Low risk & No concerns outside the assessed risk of bias domains. \\
\hline
\end{tabular}

\section{ODYSSEY KT}

\section{Study characteristics}

Methods Type of RCT: 1:1 parallel-group, double-blind, stratified RCT

Settings: outpatient care

Duration: 24 weeks

Start and stop dates: November 2014 and June 2017

\begin{tabular}{ll}
\hline Participants & Number of participants: 199 \\
Number lost to follow-up: 0 \\
Women: 35 (18\%) \\
Mean age (SD), years: $61.1(9.7)$ \\
History of CVD: $191(96 \%)$ \\
Participants with FH: 0 \\
Study enrolled people aged $\geq 18$ years with high CV risk who had inadequately controlled hypercholes- \\
terolaemia on maximally tolerated statin therapy at a stable dose for $\geq 4$ weeks before screening. \\
Background therapy: add-on to maximal tolerated statin dose \\
Randomised therapy: alirocumab vs placebo
\end{tabular}


ODYSSEY KT (Continued)

Alirocumab dose: $75-150 \mathrm{mg}$ every 2 weeks

\begin{tabular}{|c|c|c|}
\hline Outcomes & \multicolumn{2}{|l|}{ CVD, all-cause mortality } \\
\hline Notes & \multicolumn{2}{|c|}{ Funded by Sanofi and Regeneron } \\
\hline \multicolumn{3}{|l|}{ Risk of bias } \\
\hline Bias & Authors' judgement & Support for judgement \\
\hline $\begin{array}{l}\text { Random sequence genera- } \\
\text { tion (selection bias) }\end{array}$ & Unclear risk & $\begin{array}{l}\text { Not reported, most of the previous ODYSSEY trials described an automated } \\
\text { procedure. }\end{array}$ \\
\hline $\begin{array}{l}\text { Allocation concealment } \\
\text { (selection bias) }\end{array}$ & Unclear risk & $\begin{array}{l}\text { Not reported, most of the previous ODYSSEY trials described a sufficient con- } \\
\text { cealment procedure. }\end{array}$ \\
\hline $\begin{array}{l}\text { Blinding of participants } \\
\text { and personnel (perfor- } \\
\text { mance bias) } \\
\text { All outcomes }\end{array}$ & Unclear risk & Not reported, describes itself as double-blind. \\
\hline $\begin{array}{l}\text { Blinding of outcome as- } \\
\text { sessment (detection bias) } \\
\text { All outcomes }\end{array}$ & Unclear risk & $\begin{array}{l}\text { Not reported, most of the previous ODYSSEY trials had an independent adjudi- } \\
\text { cation committee. }\end{array}$ \\
\hline $\begin{array}{l}\text { Incomplete outcome data } \\
\text { (attrition bias) } \\
\text { All outcomes }\end{array}$ & Low risk & No loss to follow-up. \\
\hline $\begin{array}{l}\text { Selective reporting (re- } \\
\text { porting bias) }\end{array}$ & Low risk & Reported common endpoints. \\
\hline Other bias & Low risk & No concerns outside the assessed risk of bias domains. \\
\hline
\end{tabular}

ODYSSEY Long Term

\section{Study characteristics}

Methods

Type of RCT: 2:1 parallel-group, double-blind RCT with stratified randomisation

Settings: outpatient care

Duration: 78 weeks

Start and stop dates: January 2012 and November 2014

Participants

Number of participants: 2341

Number lost to follow-up: 247

Women: $884(38 \%)$

Mean age (SD), years: $63(11)$

History of CVD: 1607 (68\%)

Participants with FH: $415(18 \%)$ 
ODYSSEY Long Term (Continued)

Participants with heFH or established CHD or CHD risk equivalent

\begin{tabular}{|c|c|}
\hline Interventions & $\begin{array}{l}\text { Background therapy: } \mathrm{SOC} \\
\text { Randomised therapy: alirocumab vs placebo for } 78 \text { weeks } \\
\text { Alirocumab dose: } 150 \mathrm{mg} \text { every } 2 \text { weeks }\end{array}$ \\
\hline Outcomes & CVD, adverse events, all-cause mortality \\
\hline Notes & $\begin{array}{l}\text { - Blood samples were obtained after a } 10 \text {-hour overnight fast } \\
\text { - Total cholesterol, TGs, and HDL-C levels in serum were determined via CDC, National Heart Lung Blood } \\
\text { Institute Lipid Standardization Program assays } \\
\text { - LDL-C calculated using Friedewald formula at all sampling points. LDL-C was also measured via ultra- } \\
\text { centrifugation and precipitation (beta-quantification) by the central laboratory at weeks } 0,12,24,52 \text {, } \\
\text { and } 78 \text {, and in cases where TG values were }>400 \mathrm{mg} / \mathrm{dL} \\
\text { - ApoB, apolipoprotein A1, and lipoprotein(a) levels in serum were determined via immunonephelom- } \\
\text { etry } \\
\text { - NCT01507831 } \\
\text { - Funded by Sanofi and Regeneron }\end{array}$ \\
\hline
\end{tabular}

\section{Risk of bias}

\begin{tabular}{|c|c|c|}
\hline Bias & Authors' judgement & Support for judgement \\
\hline $\begin{array}{l}\text { Random sequence genera- } \\
\text { tion (selection bias) }\end{array}$ & Low risk & Central computer-generated allocation system. \\
\hline $\begin{array}{l}\text { Allocation concealment } \\
\text { (selection bias) }\end{array}$ & Low risk & Central computer-generated allocation system. \\
\hline $\begin{array}{l}\text { Blinding of participants } \\
\text { and personnel (perfor- } \\
\text { mance bias) } \\
\text { All outcomes }\end{array}$ & Low risk & $\begin{array}{l}\text { Participants and investigators were blinded with placebo identically packaged } \\
\text { as alirocumab. }\end{array}$ \\
\hline $\begin{array}{l}\text { Blinding of outcome as- } \\
\text { sessment (detection bias) } \\
\text { All outcomes }\end{array}$ & Low risk & $\begin{array}{l}\text { Biomarkers assessed at a central laboratory blinded for allocation. Clinical } \\
\text { endpoints and adverse advents were similarly assessed in a blinded method. }\end{array}$ \\
\hline $\begin{array}{l}\text { Incomplete outcome data } \\
\text { (attrition bias) } \\
\text { All outcomes }\end{array}$ & High risk & $\begin{array}{l}\text { ITT analysis excluded participants ( } 167(10.8 \%) \text { in the intervention arm and } 80 \\
(10.1 \%) \text { in the control arm) who missed LDL-C measurements during first } 24 \\
\text { weeks. In total, } 437 \text { alirocumab participants did not complete study follow-up } \\
\text { compared with } 193 \text { placebo participants. Categorical outcomes were analysed } \\
\text { using an available-case analysis. Missing biomarker values were imputed using } \\
\text { mixed models or multiple imputations. }\end{array}$ \\
\hline $\begin{array}{l}\text { Selective reporting (re- } \\
\text { porting bias) }\end{array}$ & Low risk & Reported protocol-defined endpoints. \\
\hline Other bias & Low risk & No concerns outside the assessed risk of bias domains. \\
\hline
\end{tabular}

\section{ODYSSEY MONO}

\section{Study characteristics}

PCSK9 monoclonal antibodies for the primary and secondary prevention of cardiovascular disease (Review) 
ODYSSEY MONO (Continued)

Methods
Type of RCT: 1:1 parallel-group, double-blind RCT

Settings: outpatient care

Duration: 24 weeks

Start and stop dates: July 2012 and July 2013

Participants with 10-year risk of fatal CV events between $1 \%$ and $<5 \%$

Interventions

Background therapy: National Cholesterol Education Program Adult Treatment Panel III therapeutic lifestyle changes diet

Randomised therapy: alirocumab and placebo ezetimibe daily vs ezetimibe $10 \mathrm{mg}$ daily plus alirocumab biweekly placebo

Alirocumab dose: 24 weeks 75 mg every 2 weeks, at 12 weeks LDL-C-dependent uptitration occurred to $150 \mathrm{mg}$ biweekly. Resulting in a 2-week equivalent dose of $75-150 \mathrm{mg}$

\begin{tabular}{ll}
\hline Outcomes & CVD, adverse events \\
\hline Notes & - LDL-C calculated using Friedewald formula \\
& - NCT01644474 \\
& - Funded by Sanofi and Regeneron
\end{tabular}

\section{Risk of bias}

\begin{tabular}{lll}
\hline Bias & Authors' judgement & Support for judgement \\
\hline $\begin{array}{l}\text { Random sequence genera- } \\
\text { tion (selection bias) }\end{array}$ & Unclear risk & Not reported. \\
\hline
\end{tabular}

\begin{tabular}{lll}
\hline $\begin{array}{l}\text { Allocation concealment } \\
\text { (selection bias) }\end{array}$ & Low risk & Permuted-block design. \\
\hline $\begin{array}{l}\text { Blinding of participants } \\
\begin{array}{l}\text { and personnel (perfor- } \\
\text { mance bias) }\end{array}\end{array}$ & Low risk & $\begin{array}{l}\text { Participants were blinded for treatment allocation and self-administered } \\
\text { treatments. }\end{array}$ \\
$\begin{array}{l}\text { All outcomes } \\
\text { outcolis }\end{array}$ & \\
\hline
\end{tabular}

Blinding of outcome as-
sessment (detection bias) $\quad$ Eow risk $\quad$ Endpoint adjudication was blinded and central laboratory.

All outcomes

Incomplete outcome data Low risk $\quad$ All participants were available at 24 weeks of follow-up.
(attrition bias)

All outcomes 
ODYSSEY MONO (Continued)

Selective reporting (re- Low risk Reported protocol-defined endpoints. porting bias)

Other bias

Low risk

No concerns outside the assessed risk of bias domains.

\section{ODYSSEY OPTIONS I}

\section{Study characteristics}

\begin{tabular}{|c|c|}
\hline Methods & $\begin{array}{l}\text { Type of RCT: 2:1 parallel-group, double-blind, stratified, permuted-block designed RCT } \\
\text { Settings: outpatient care } \\
\text { Duration: } 24 \text { weeks } \\
\text { Start and stop dates: NA }\end{array}$ \\
\hline Participants & $\begin{array}{l}\text { Number of participants: } 355 \\
\text { Number lost to follow-up: } 10 \\
\text { Women: } 124(35 \%) \\
\text { Mean age (SD), years: } 63(10) \\
\text { History of CVD: } 200(56 \%) \\
\text { FH participants: } 31(9 \%) \\
\text { Participants with history of CVD and LDL-C levels } \geq 70 \mathrm{mg} / \mathrm{dL} \text {, or CVD risk factors and LDL-C } \geq 100 \mathrm{mg} / \mathrm{dL}\end{array}$ \\
\hline Interventions & $\begin{array}{l}\text { Background therapy: } 24 \text { weeks } 20 \mathrm{mg} \text { or } 40 \mathrm{mg} \text { of baseline atorvastatin and National Cholesterol Edu- } \\
\text { cation Program Adult Treatment Panel III } \\
\text { Randomised therapy: alirocumab vs ezetimibe } 10 \mathrm{mg} / \text { day, or atorvastatin } 20 \mathrm{mg} \text { or } 40 \mathrm{mg} \text {, or atorvas- } \\
\text { tatin } 40 \mathrm{mg} \text { regimen only, switch to rosuvastatin } \\
40 \mathrm{mg} \\
\text { Alirocumab dose: } 75 \mathrm{mg} \text { every } 2 \text { weeks, with uptitration to } 150 \mathrm{mg} \text { at week } 12 \text {. Resulting in a 2-week } \\
\text { equivalent dose of } 75-150 \mathrm{mg} \\
\text { Resulting in } 7 \text { groups } \\
\text { - atorvastatin } 20 \mathrm{mg} \text { plus alirocumab } 75 \mathrm{mg} \text { every } 2 \text { weeks } \\
\text { - atorvastatin } 20 \mathrm{mg} \text { plus ezetimibe } 10 \mathrm{mg} \text { every day } \\
\text { - atorvastatin } 20 \mathrm{mg} \text { plus atorvastatin } 20 \mathrm{mg} \text { every day } \\
\text { - atorvastatin } 40 \mathrm{mg} \text { plus alirocumab } 75 \mathrm{mg} \text { every } 2 \text { weeks } \\
\text { - atorvastatin } 40 \mathrm{mg} \text { plus ezetimibe } 10 \mathrm{mg} \text { every day } \\
\text { - atorvastatin } 40 \mathrm{mg} \text { plus atorvastatin } 40 \mathrm{mg} \text { every day } \\
\text { - rosuvastatin } 40 \mathrm{mg} \\
\text { All blinded with placebo alirocumab and over-encapsulated tables for ezetimibe, atorvastatin, and ro- } \\
\text { suvastatin }\end{array}$ \\
\hline Outcomes & CVD, adverse events, all-cause mortality \\
\hline Notes & $\begin{array}{l}\text { - Unless otherwise specified, comparisons are made of alirocumab therapy vs pooled other therapies } \\
\text { - Fasting blood samples were collected in the morning }\end{array}$ \\
\hline
\end{tabular}


ODYSSEY OPTIONS I (Continued)

- LDL-C calculated using Friedewald formula

- Lipoprotein(a) was analysed using an immunoradiometric assay on the Siemens BNII

- NCT01730040

- Funded by Sanofi and Regeneron

\section{Risk of bias}

\begin{tabular}{|c|c|c|}
\hline Bias & Authors' judgement & Support for judgement \\
\hline $\begin{array}{l}\text { Random sequence genera- } \\
\text { tion (selection bias) }\end{array}$ & Low risk & $\begin{array}{l}\text { Centralised interactive voice-response system or interactive web-response } \\
\text { system. }\end{array}$ \\
\hline $\begin{array}{l}\text { Allocation concealment } \\
\text { (selection bias) }\end{array}$ & Low risk & Permuted-block design and central allocation. \\
\hline $\begin{array}{l}\text { Blinding of participants } \\
\text { and personnel (perfor- } \\
\text { mance bias) } \\
\text { All outcomes }\end{array}$ & Low risk & Both blinded. \\
\hline $\begin{array}{l}\text { Blinding of outcome as- } \\
\text { sessment (detection bias) } \\
\text { All outcomes }\end{array}$ & Low risk & Endpoint adjudication was blinded and central laboratory. \\
\hline $\begin{array}{l}\text { Incomplete outcome data } \\
\text { (attrition bias) } \\
\text { All outcomes }\end{array}$ & Low risk & $\begin{array}{l}4(3.85 \%) \text { participants in the alirocumab arm had missing lipids measurements } \\
\text { compared with } 6(2.39 \%) \text { in the comparator arm. Additionally, mixed-effects } \\
\text { (ANCOVA) models were used. }\end{array}$ \\
\hline $\begin{array}{l}\text { Selective reporting (re- } \\
\text { porting bias) }\end{array}$ & Low risk & Reported protocol-defined endpoints. \\
\hline Other bias & Low risk & No concerns outside the assessed risk of bias domains. \\
\hline
\end{tabular}

\section{Study characteristics}

Methods

Type of RCT: double-blind, placebo-controlled, parallel-group RCT

Settings: outpatient care

Duration: 24 weeks

Start and stop dates: NA

Participants

\section{Number of participants: 305}

Number lost to follow-up: 7

Women: 118 (39\%)

Mean age (SD), years: 61 (10)

History of CVD: 177 (58\%)

Participants with FH: 41 (13\%)

Participants with history of CVD and LDL-C levels $\geq 70 \mathrm{mg} / \mathrm{dL}$, or CVD risk factors and LDL-C $\geq 100 \mathrm{mg} / \mathrm{dL}$ 
ODYSSEY OPTIONS II (Continued)

Interventions

Background therapy: participants received 24 weeks baseline rosuvastatin $10 \mathrm{mg}$ or $20 \mathrm{mg}$ and $\mathrm{Na}-$ tional Cholesterol Education Program Adult Treatment Panel III

Randomised therapy: alirocumab vs add-on ezetimibe $10 \mathrm{mg} /$ day, or additional rosuvastatin $10 \mathrm{mg}$ or $20 \mathrm{mg}$

Alirocumab dose: add-on of $75 \mathrm{mg}$ every 2 weeks, with uptitration to $150 \mathrm{mg}$ at week 12 . Resulting in a 2-week equivalent dose of 75-150 mg

Resulting in 6 groups

- rosuvastatin $10 \mathrm{mg}$ plus alirocumab $75 \mathrm{mg}$ every 2 weeks

- rosuvastatin $10 \mathrm{mg}$ plus ezetimibe $10 \mathrm{mg}$ every day

- rosuvastatin $10 \mathrm{mg}$ plus rosuvastatin $10 \mathrm{mg}$ every day

- rosuvastatin $20 \mathrm{mg}$ plus alirocumab 75 mg every 2 weeks

- rosuvastatin $20 \mathrm{mg}$ plus ezetimibe every day

- rosuvastatin $20 \mathrm{mg}$ plus rosuvastatin $20 \mathrm{mg}$ every day

All blinded with placebo alirocumab and overencapsulated tables for ezetimibe, rosuvastatin

\begin{tabular}{ll}
\hline Outcomes & CVD, any adverse events, all-cause mortality \\
\hline Notes & - Unless otherwise specified, comparisons were made of alirocumab therapy vs pooled other therapies \\
- Fasting blood samples were collected in the morning \\
- LDL-C calculated using Friedewald formula \\
- NCT01730053 \\
- Funded by Sanofi and Regeneron
\end{tabular}

\section{Risk of bias}

\begin{tabular}{|c|c|c|}
\hline Bias & Authors' judgement & Support for judgement \\
\hline $\begin{array}{l}\text { Random sequence genera- } \\
\text { tion (selection bias) }\end{array}$ & Low risk & $\begin{array}{l}\text { Centralised interactive voice-response system or interactive web-response } \\
\text { system. }\end{array}$ \\
\hline $\begin{array}{l}\text { Allocation concealment } \\
\text { (selection bias) }\end{array}$ & Low risk & Permuted-block design and central allocation. \\
\hline $\begin{array}{l}\text { Blinding of participants } \\
\text { and personnel (perfor- } \\
\text { mance bias) } \\
\text { All outcomes }\end{array}$ & Low risk & Both blinded. \\
\hline $\begin{array}{l}\text { Blinding of outcome as- } \\
\text { sessment (detection bias) } \\
\text { All outcomes }\end{array}$ & Low risk & Endpoint adjudication was blinded and central laboratory. \\
\hline $\begin{array}{l}\text { Incomplete outcome data } \\
\text { (attrition bias) } \\
\text { All outcomes }\end{array}$ & Low risk & $\begin{array}{l}2(1.94 \%) \text { participants in the alirocumab arm had missing lipid measurements } \\
\text { compared with } 5(2.48 \%) \text { in the comparator arms. Additionally, mixed-effects } \\
\text { (ANCOVA) models were used. }\end{array}$ \\
\hline $\begin{array}{l}\text { Selective reporting (re- } \\
\text { porting bias) }\end{array}$ & Low risk & Reported protocol-defined endpoints. \\
\hline Other bias & Low risk & No concerns outside the assessed risk of bias domains. \\
\hline
\end{tabular}




\section{Study characteristics}

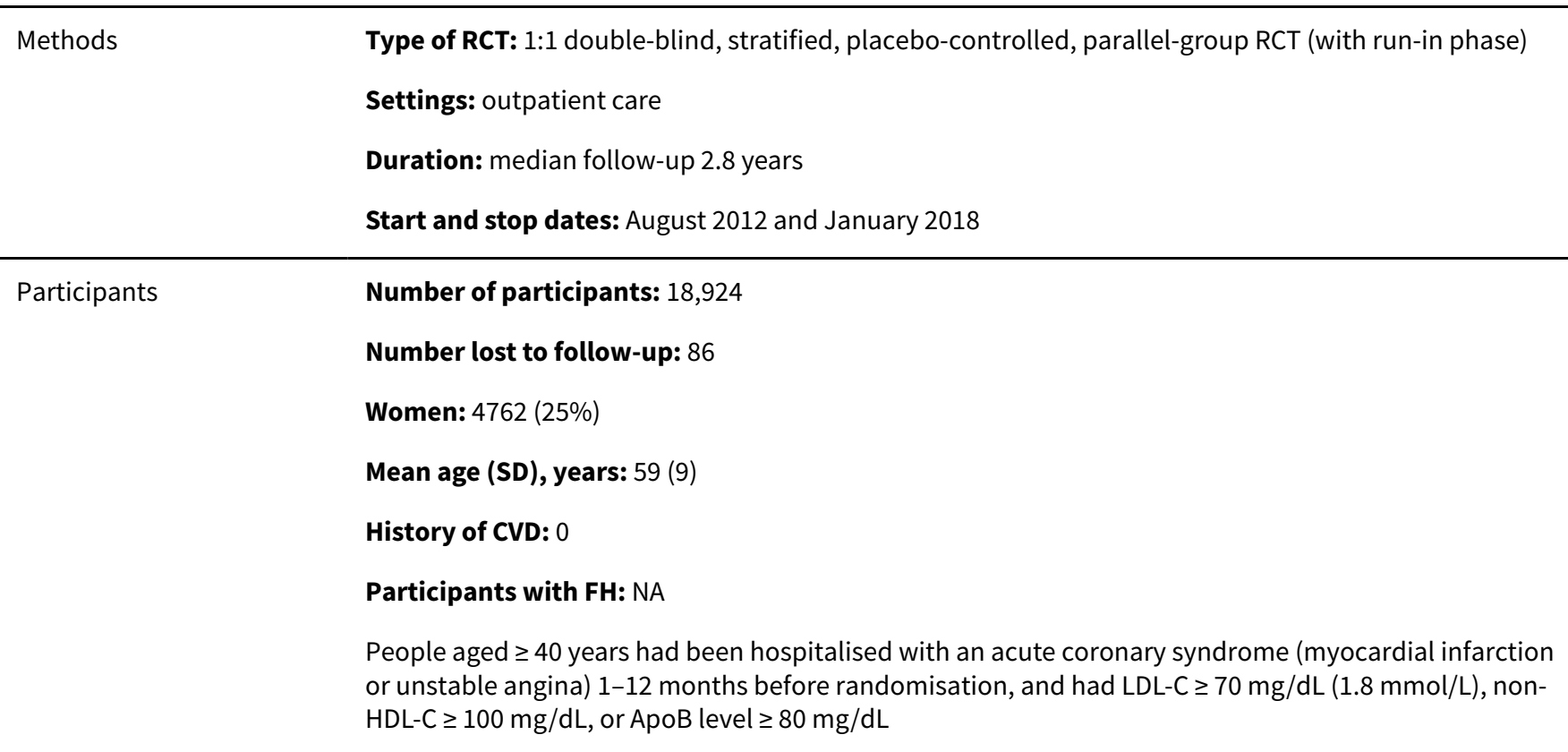

Interventions

Background therapy: minimum of 2 weeks of stable treatment with atorvastatin $40-80 \mathrm{mg}$ once daily, rosuvastatin 20-40 mg once daily, or maximum tolerated dose of 1 of these statins (including no statin in the case of documented unacceptable adverse effects)

Randomised therapy: alirocumab vs placebo

Alirocumab dose: 75 mg every 2 weeks followed by blinded, lipid-guided adjustment.

\section{Outcomes}

CVD, defined as a composite of: death from CHD, non-fatal myocardial infarction, unstable angina requiring hospitalisation, and ischaemia-driven coronary revascularisation

Notes Funded by Sanofi and Regeneron

\section{Risk of bias}

\begin{tabular}{|c|c|c|}
\hline Bias & Authors' judgement & Support for judgement \\
\hline \multirow{2}{*}{$\begin{array}{l}\text { Random sequence genera- } \\
\text { tion (selection bias) }\end{array}$} & Low risk & Centralised treatment allocation system. \\
\hline & & $\begin{array}{l}\text { Quote: "the Interactive Voice Response System (IVRS) and the Interactive Web } \\
\text { Response System (IWRS) depending on the choice of the site." }\end{array}$ \\
\hline $\begin{array}{l}\text { Allocation concealment } \\
\text { (selection bias) }\end{array}$ & Low risk & Placebo controlled. \\
\hline $\begin{array}{l}\text { Blinding of participants } \\
\text { and personnel (perfor- } \\
\text { mance bias) } \\
\text { All outcomes }\end{array}$ & Low risk & $\begin{array}{l}\text { Quote: "The trial-group assignments and lipid levels during the trial were con- } \\
\text { cealed from the patients and investigators." }\end{array}$ \\
\hline $\begin{array}{l}\text { Blinding of outcome as- } \\
\text { sessment (detection bias) } \\
\text { All outcomes }\end{array}$ & Low risk & Independent Clinical Events Committee \\
\hline
\end{tabular}


ODYSSEY OUTCOMES (Continued)
Incomplete outcome data Low risk
86/18,924 participants lost to follow-up.
(attrition bias)

All outcomes

Selective reporting (re- Low risk $\quad$ Reported protocol-defined endpoints.
porting bias)

Other bias Low risk No concerns outside the assessed risk of bias domains.

OSLER-1

\section{Study characteristics}

\begin{tabular}{|c|c|}
\hline Methods & $\begin{array}{l}\text { Type of RCT: } 1: 2 \text { parallel-group, open-label stratified trial } \\
\text { Settings: outpatient care } \\
\text { Duration: } 52 \text { weeks } \\
\text { Start and stop dates: October } 2011 \text { and July } 2018 \text { (including single-arm extension) }\end{array}$ \\
\hline Participants & $\begin{array}{l}\text { Number of participants: } 1104 \\
\text { Number lost to follow-up: } 169 \\
\text { Women: } 610(55 \%) \\
\text { Mean age (SD), years: } 56(12) \\
\text { History of CVD: } 210(19 \%) \\
\text { FH participants: } 414(38 \%) \\
\text { Participants with and without a history of CVD or FH; all were previously enrolled in phase } 2 \text { PCSK9 in- } \\
\text { hibitor trials and completed these trials without serious adverse events }\end{array}$ \\
\hline Interventions & $\begin{array}{l}\text { Background therapy: } \mathrm{SOC} \\
\text { Randomised therapy: evolocumab vs SOC for } 52 \text { weeks } \\
\text { Evolocumab dose: } 420 \mathrm{mg} \text { every } 4 \text { weeks, resulting in a 2-week equivalent dose of } 210 \mathrm{mg}\end{array}$ \\
\hline Outcomes & CVD, adverse events, all-cause mortality \\
\hline Notes & $\begin{array}{l}\text { - Plasma lipids, ApoA1, ApoB, and lipoprotein(a) were measured after a fast } \geq 9 \text { hours } \\
\text { - LDL-C values based on the preparative ultracentrifugation method } \\
\text { - Lipoprotein(a) assay type: Polymedco Cortlandt Manor, NY, on the Olympus Analyzer } \\
\text { - NCT01439880 } \\
\text { - Funded by Amgen }\end{array}$ \\
\hline
\end{tabular}

\section{Risk of bias}

\begin{tabular}{lll}
\hline Bias & Authors' judgement & Support for judgement \\
\hline $\begin{array}{l}\text { Random sequence genera- } \\
\text { tion (selection bias) }\end{array}$ & Low risk & $\begin{array}{l}\text { Randomisation performed centrally using an interactive voice-response or } \\
\text { web-response system. }\end{array}$ \\
\hline
\end{tabular}


OSLER-1 (Continued)

Allocation concealment Low risk Central allocation.
(selection bias)

\begin{tabular}{|c|c|c|}
\hline Blinding of participants & High risk & $\begin{array}{l}\text { No blinding. Lack of blinding will likely cause a change in adherence or in par- } \\
\text { ticipants regarding SOC/lifestyle (or both) that may have influenced outcomes. }\end{array}$ \\
\hline
\end{tabular}

mance bias)

All outcomes

Blinding of outcome as-
sessment (detection bias) $\quad$ High risk Outcomes such as adverse events may be biased owing to detection bias.

All outcomes

\begin{tabular}{lll}
\hline $\begin{array}{l}\text { Incomplete outcome data } \\
\begin{array}{l}\text { (attrition bias) } \\
\text { All outcomes }\end{array}\end{array}$ & High risk & $\begin{array}{l}\text { At week 52, 73/368 (19.83\%) of SOC arm dropped out, and 96/736 (13.04\%) of } \\
\text { intervention arm dropped out. No mention of how missing data were handled. }\end{array}$ \\
\hline $\begin{array}{l}\text { Selective reporting (re- } \\
\text { porting bias) }\end{array}$ & Low risk & Reported protocol-defined endpoints. \\
\hline Other bias & Low risk & No concerns outside the assessed risk of bias domains. \\
\hline
\end{tabular}

\section{OSLER-2}

\section{Study characteristics}

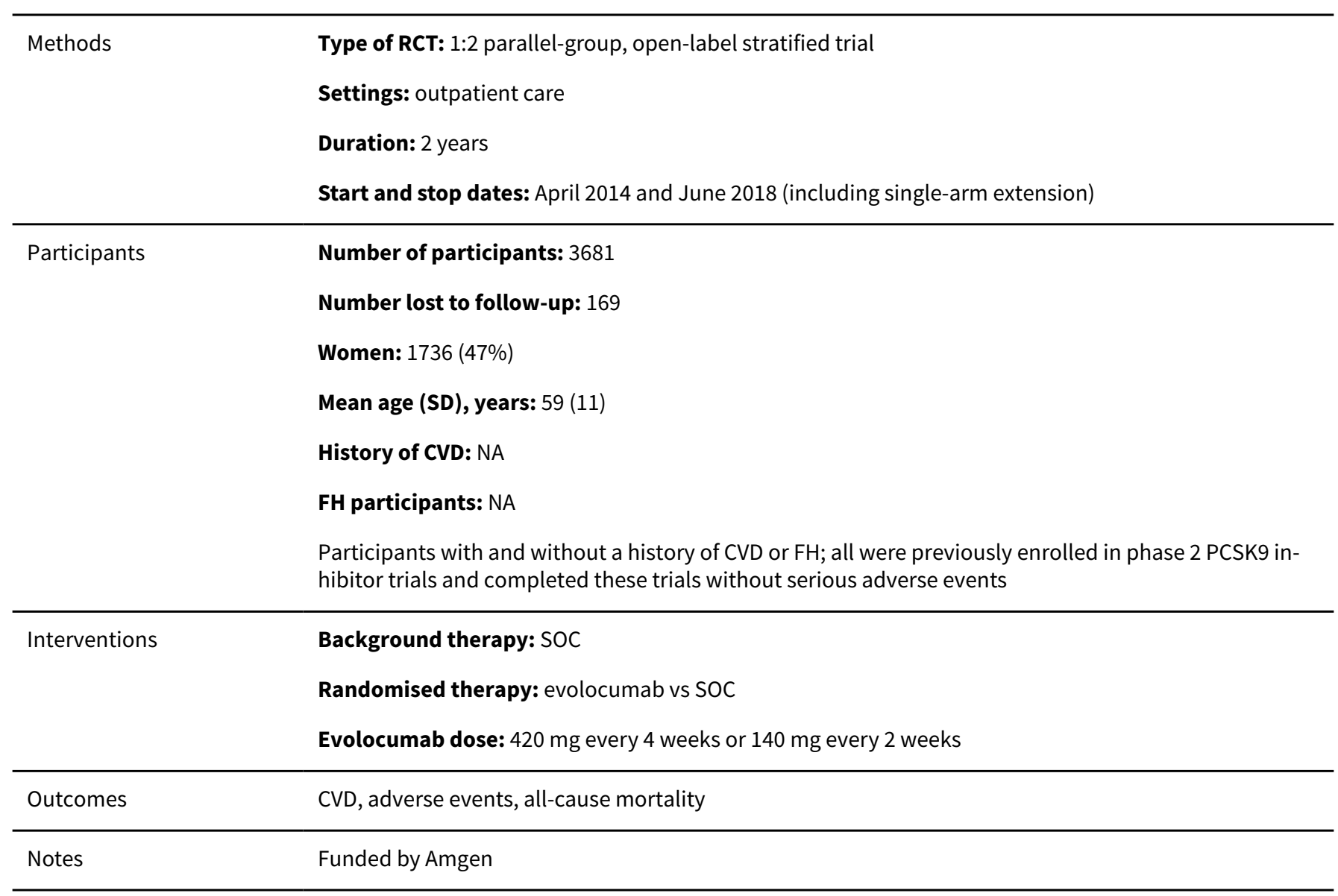


OSLER-2 (Continued)

\section{Risk of bias}

\begin{tabular}{|c|c|c|}
\hline Bias & Authors' judgement & Support for judgement \\
\hline $\begin{array}{l}\text { Random sequence genera- } \\
\text { tion (selection bias) }\end{array}$ & Low risk & $\begin{array}{l}\text { Randomisation was performed centrally using an interactive voice-response or } \\
\text { web-response system. }\end{array}$ \\
\hline $\begin{array}{l}\text { Allocation concealment } \\
\text { (selection bias) }\end{array}$ & Low risk & Central allocation. \\
\hline $\begin{array}{l}\text { Blinding of participants } \\
\text { and personnel (perfor- } \\
\text { mance bias) } \\
\text { All outcomes }\end{array}$ & High risk & No blinding. \\
\hline $\begin{array}{l}\text { Blinding of outcome as- } \\
\text { sessment (detection bias) } \\
\text { All outcomes }\end{array}$ & High risk & No blinding. \\
\hline $\begin{array}{l}\text { Incomplete outcome data } \\
\text { (attrition bias) } \\
\text { All outcomes }\end{array}$ & Unclear risk & Unclear. \\
\hline $\begin{array}{l}\text { Selective reporting (re- } \\
\text { porting bias) }\end{array}$ & Low risk & Traditional endpoints. \\
\hline Other bias & Low risk & No concerns outside the assessed risk of bias domains. \\
\hline
\end{tabular}

\section{Sugizaki 2019}

\section{Study characteristics}

\begin{tabular}{ll}
\hline Methods & Type of RCT: 1:1 parallel-group trial \\
Settings: outpatient care \\
Duration: NA \\
Start and stop dates: NA \\
\hline Number of participants: 24 \\
Number lost to follow-up: NA \\
Women: NA \\
Mean age (SD), years: NA \\
History of CVD: NA \\
FH participants: NA \\
People with thin-cap fibroatheroma \\
\hline
\end{tabular}

Interventions

\section{Background therapy: SOC}

Randomised therapy: alirocumab vs rosuvastatin $10 \mathrm{mg} /$ day 
Sugizaki 2019 (Continued)

Evolocumab dose: $75 \mathrm{mg} / 2$ weeks

\begin{tabular}{ll}
\hline Outcomes & Did not report on outcomes relevant for this study. \\
\hline Notes & Only available in abstract form. \\
\hline
\end{tabular}

\section{Risk of bias}

\begin{tabular}{lll}
\hline Bias & Authors' judgement & Support for judgement \\
\hline $\begin{array}{l}\text { Random sequence genera- } \\
\text { tion (selection bias) }\end{array}$ & Unclear risk & Only available in abstract form; insufficient detail on randomisation method. \\
\hline
\end{tabular}

\begin{tabular}{|c|c|c|}
\hline $\begin{array}{l}\text { Allocation concealment } \\
\text { (selection bias) }\end{array}$ & Unclear risk & Only available in abstract form; insufficient detail on randomisation method. \\
\hline $\begin{array}{l}\text { Blinding of participants } \\
\text { and personnel (perfor- } \\
\text { mance bias) } \\
\text { All outcomes }\end{array}$ & High risk & $\begin{array}{l}\text { Judged on the abstract, it seems the study did not use placebo to conceal allo- } \\
\text { cated treatment. }\end{array}$ \\
\hline $\begin{array}{l}\text { Blinding of outcome as- } \\
\text { sessment (detection bias) } \\
\text { All outcomes }\end{array}$ & Unclear risk & Only available in abstract form; insufficient detail on blinding method. \\
\hline $\begin{array}{l}\text { Incomplete outcome data } \\
\text { (attrition bias) } \\
\text { All outcomes }\end{array}$ & Low risk & $\begin{array}{l}\text { The scatter dots plot of } 36 \text { measurements added up to } 24 \text { (to total number of } \\
\text { allocated participants). }\end{array}$ \\
\hline $\begin{array}{l}\text { Selective reporting (re- } \\
\text { porting bias) }\end{array}$ & High risk & $\begin{array}{l}\text { The abstract only reported on plaque-related outcomes. Full report might re- } \\
\text { port more. }\end{array}$ \\
\hline Other bias & Low risk & No concerns outside the assessed risk of bias domains. \\
\hline
\end{tabular}

ANCOVA: analysis of covariance; ApoB: apolipoprotein B; BMI: body mass index; CABG: coronary artery bypass graft; CDC: Centers for Disease Control and Prevention; CHD: coronary heart disease; CV: cardiovascular; CVD: cardiovascular disease; FH: familial hypercholesterolaemia; HbAlc: glycosylated haemoglobin; HDL-C: high-density lipoprotein cholesterol; heFH: heterozygous familial hypercholesterolaemia; hs-CRP: high-sensitivity C-reactive protein; ITT: intention-to-treat; IVUS: intravascular ultrasound; LDL-C: lowdensity lipoprotein cholesterol; LLT: lipid-lowering therapy; LMT: lipid modifying treatments; PAD: peripheral artery disease; MACE: major adverse cardiac events; NA: not available; NYHA: New York Heart Association; RCT: randomised controlled trial; SD: standard deviation; SOC: standard of care; T2DM: type 2 diabetes mellitus; TG: triglycerides; TSH: thyroid-stimulating hormone; TIA: transient ischaemic attack; ULN: upper limit of normal.

Characteristics of excluded studies [ordered by study ID]

\begin{tabular}{ll}
\hline Study & Reason for exclusion \\
\hline ANITSCHKOW & Follow-up time too short. \\
\hline Ballantyne 2015 & Terminated PCSK9 monoclonal antibodies. \\
\hline Baruch 2013 & Follow-up time too short. \\
\hline Cho 2014 & Follow-up time too short. \\
\hline Desai 2014 & Follow-up time too short. \\
\hline \hline
\end{tabular}




\begin{tabular}{|c|c|}
\hline Study & Reason for exclusion \\
\hline Dias 2012 & Follow-up time too short. \\
\hline Dufour 2012 & Meta-analysis without separate results. \\
\hline EBBINGHAUS & Subset of the included FOURIER trial. \\
\hline EQUATOR & Terminated PCSK9 monoclonal antibodies. \\
\hline Gaudet 2012 & Meta-analysis of 3 studies without separate results. \\
\hline Gaudet 2013 & Meta-analysis of 3 studies without separate results. \\
\hline Gumbiner 2012 & Follow-up time too short. \\
\hline Habibinejad 2016 & No relevant data. \\
\hline HAUSER-RCT & Enrolled children. \\
\hline Hopkins 2013 & Follow-up time too short. \\
\hline Jones 2015 & Meta-analysis of 4 studies without separate results. \\
\hline Kastelein 2015 & Follow-up time too short. \\
\hline Kawashiri 2012 & No randomisation to PCSK9 inhibitor. \\
\hline Mabuchi 2015 & No empirical results. \\
\hline Maxwell 2012 & No empirical results. \\
\hline Mearns 2014 & No empirical results. \\
\hline Pordy 2013 & Dose-response modelling. \\
\hline Raal 2014a & Meta-analysis without separate results. \\
\hline Raal 2014b & Follow-up time too short. \\
\hline Shaywitz 2012 & Follow-up time too short. \\
\hline SPIRE $1 / 2$ & Terminated PCSK9 monoclonal antibodies. \\
\hline SPIRE biomarker trials & Terminated PCSK9 monoclonal antibodies. \\
\hline Stawowy 2014 & Follow-up time too short. \\
\hline Stein 2012 & This reference published on a subset of the data included in OSLER-1. \\
\hline Stein 2013 & Follow-up time too short. \\
\hline Swergold 2010 & Follow-up time too short. \\
\hline Swergold 2011 & Follow-up time too short. \\
\hline TAUSSIG & Enrolled children. \\
\hline
\end{tabular}




\section{Study}

Wan 2013

\section{Reason for exclusion}

Follow-up time too short.

Characteristics of ongoing studies [ordered by study ID]

\section{ALTAIR}

Study name

Methods

Participants

Interventions

Outcomes

Starting date NA

Contact information

NA

\section{ALTAIR}

Phase IV, open-label, randomised, parallel-group, single-centre study

Japanese adults hospitalised for $\mathrm{PCl}$ and having suboptimal control of LDL-C levels (> $70 \mathrm{mg} / \mathrm{dL}$ ) despite statin therapy.

Alirocumab $75 \mathrm{mg}$ every 2 weeks added to rosuvastatin $10 \mathrm{mg} /$ day

Rosuvastatin $10 \mathrm{mg} /$ day, with initiation or dose adjustment (or both) of non-statin lipid-lowering to achieve an LDL-C target of $<70 \mathrm{mg} / \mathrm{dL}$

Notes

EVOLVD

$\begin{array}{ll}\text { Study name } & \begin{array}{l}\text { Cholesterol lowering with EVOLocumab to prevent cardiac allograft vasculopathy in de-no } \\ \text { vo heart transplant recipients (EVOLVD) }\end{array}\end{array}$

\begin{tabular}{ll}
\hline Methods & Parallel arm RCT \\
\hline Participants & De novo heart transplant recipients \\
\hline Interventions & Evolocumab \\
& Placebo \\
\hline
\end{tabular}

\section{Outcomes}

Starting date November 2018

\section{Contact information}

\section{Notes}


NCT02833844

\begin{tabular}{ll}
\hline Study name & $\begin{array}{l}\text { Double-blind, randomised, placebo-controlled, multicentre study to evaluate safety, tolerability, } \\
\text { and efficacy on LDL-C of evolocumab (AMG 145) in subjects with HIV and with hyperlipidaemia or } \\
\text { mixed dyslipidaemia, or both }\end{array}$ \\
\hline Methods & Parallel RCT \\
\hline Participants & HIV-positive participants with hyperlipidaemia or mixed dyslipidaemia (timeframe: week 24) \\
\hline Interventions & Evolocumab \\
\hline Outcomes & Placebo \\
\hline Starting date & Percent change from baseline in LDL-C \\
\hline Contact information 2016 \\
\hline Notes & Amgen \\
\hline
\end{tabular}

UMIN000034592

\begin{tabular}{ll}
\hline Study name & NA \\
\hline Methods & NA \\
\hline Participants & NA \\
\hline Interventions & NA \\
\hline Outcomes & NA \\
\hline Starting date & 26 October 2018 \\
\hline Contact information & upload.umin.ac.jp/cgi-open-bin/ctr_e/ctr_view.cgi?recptno=R000039437 \\
\hline Notes & $\begin{array}{l}\text { Comparative clinical study of alilocumab (Praluent) and evorocumab (Repatha) for dys- } \\
\text { lipidaemia }\end{array}$ \\
\hline
\end{tabular}

LDL-C: low-density lipoprotein cholesterol; NA: not available; PCI: percutaneous coronary intervention; RCT: randomised controlled trial.

\section{DATA AND ANALYSES}

\section{Comparison 1. Alirocumab versus placebo}

\begin{tabular}{lllll}
\hline Outcome or subgroup title & $\begin{array}{l}\text { No. of } \\
\text { studies }\end{array}$ & $\begin{array}{l}\text { No. of } \\
\text { partici- } \\
\text { pants }\end{array}$ & Statistical method & Effect size \\
\hline 1.1 Any cardiovascular disease & 10 & 23868 & Odds Ratio (IV, Fixed, 95\% CI) & $0.87[0.80,0.94]$ \\
\hline
\end{tabular}




\begin{tabular}{lllll}
\hline Outcome or subgroup title & $\begin{array}{l}\text { No. of } \\
\text { studies }\end{array}$ & $\begin{array}{l}\text { No. of } \\
\text { partici- } \\
\text { pants }\end{array}$ & Statistical method & Effect size \\
\hline 1.2 All-cause mortality & 12 & 24797 & Odds Ratio (IV, Fixed, 95\% Cl) & $0.83[0.72,0.96]$ \\
\hline 1.3 Any myocardial infarction & 9 & 23352 & Odds Ratio (IV, Fixed, 95\% Cl) & $0.86[0.79,0.94]$ \\
\hline 1.4 Any stroke & 8 & 22835 & Odds Ratio (IV, Fixed, 95\% Cl) & $0.73[0.58,0.91]$ \\
\hline 1.5 Influenza & 11 & 23964 & Odds Ratio (IV, Fixed, 95\% Cl) & $1.09[0.83,1.42]$ \\
\hline 1.6 Type 2 diabetes mellitus & 6 & 22306 & Odds Ratio (IV, Fixed, 95\% Cl) & $0.96[0.86,1.07]$ \\
\hline 1.7 Any cancer & 6 & 3806 & Odds Ratio (IV, Fixed, 95\% Cl) & $0.88[0.61,1.26]$ \\
\hline 1.8 Hypertension & 10 & 24347 & Odds Ratio (IV, Fixed, 95\% Cl) & $0.92[0.72,1.18]$ \\
\hline
\end{tabular}

\section{Analysis 1.1. Comparison 1: Alirocumab versus placebo, Outcome 1: Any cardiovascular disease}

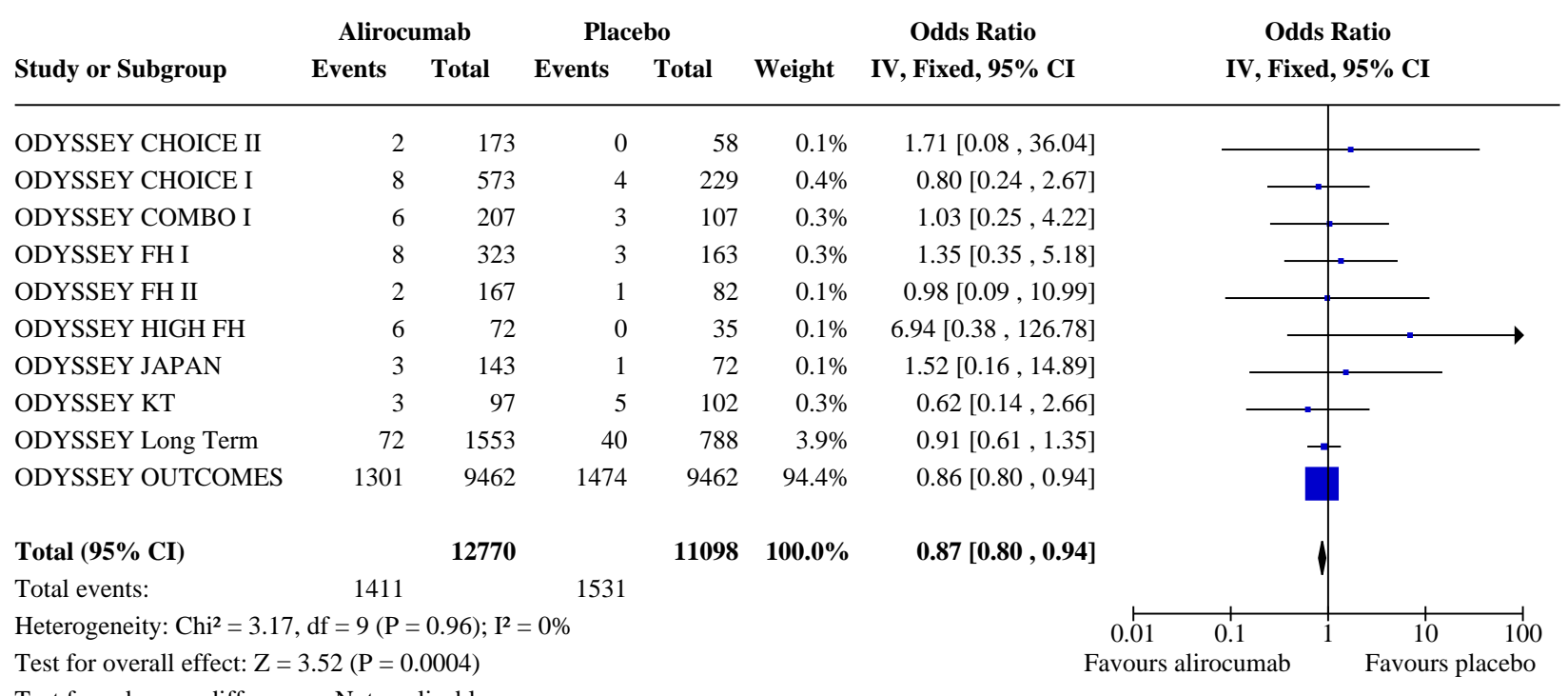


Analysis 1.2. Comparison 1: Alirocumab versus placebo, Outcome 2: All-cause mortality

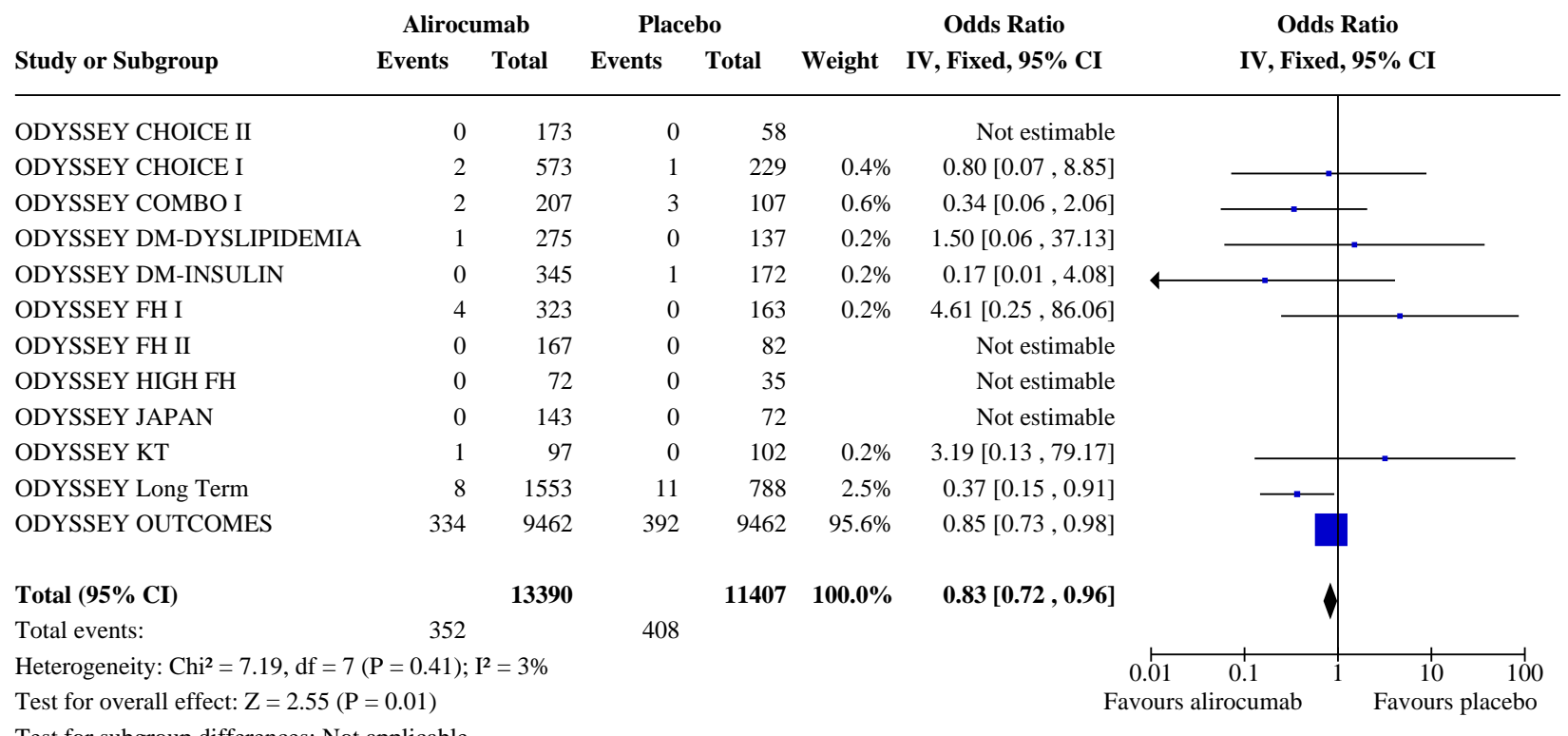

Analysis 1.3. Comparison 1: Alirocumab versus placebo, Outcome 3: Any myocardial infarction

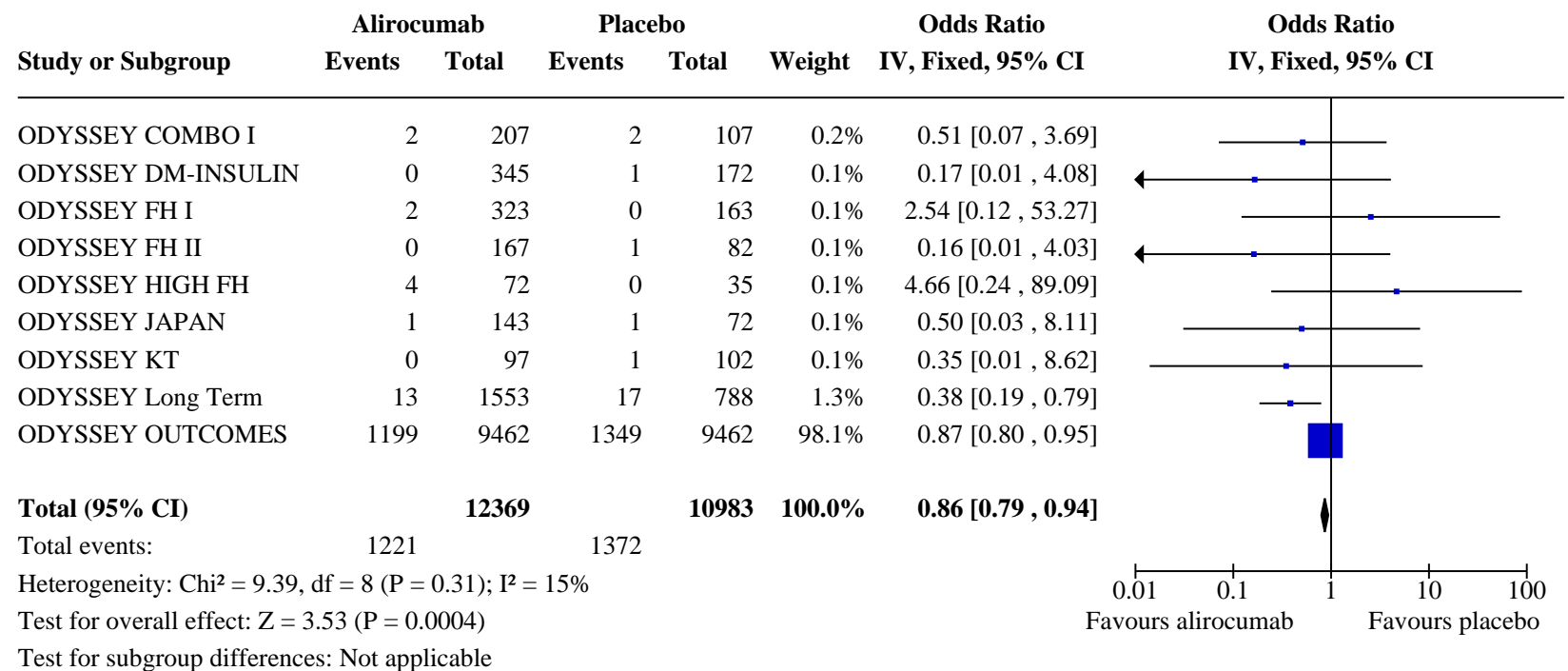


Analysis 1.4. Comparison 1: Alirocumab versus placebo, Outcome 4: Any stroke

\begin{tabular}{|c|c|c|c|c|c|c|c|}
\hline & Aliro & nab & Pla & & & Odds Ratio & Odds Ratio \\
\hline Study or Subgroup & Events & Total & Events & Total & Weight & IV, Fixed, 95\% CI & IV, Fixed, 95\% CI \\
\hline
\end{tabular}

\begin{tabular}{lrrrrrr}
\hline ODYSSEY COMBO I & 2 & 207 & 0 & 107 & $0.6 \%$ & $2.62[0.12,54.97]$ \\
ODYSSEY FH I & 1 & 323 & 0 & 163 & $0.5 \%$ & $1.52[0.06,37.54]$ \\
ODYSSEY FH II & 0 & 167 & 0 & 82 & & Not estimable \\
ODYSSEY HIGH FH & 0 & 72 & 0 & 35 & & Not estimable \\
ODYSSEY JAPAN & 2 & 143 & 1 & 72 & $0.9 \%$ & $1.01[0.09,11.30]$ \\
ODYSSEY KT & 0 & 97 & 1 & 102 & $0.5 \%$ & $0.35[0.01,8.62]$ \\
ODYSSEY Long Term & 10 & 1553 & 3 & 788 & $3.1 \%$ & $1.70[0.47,6.18]$ \\
ODYSSEY OUTCOMES & 120 & 9462 & 171 & 9462 & $94.4 \%$ & $0.70[0.55,0.88]$ \\
& & & & & & \\
Total (95\% CI) & & $\mathbf{1 2 0 2 4}$ & & $\mathbf{1 0 8 1 1}$ & $\mathbf{1 0 0 . 0 \%}$ & $\mathbf{0 . 7 3}[\mathbf{0 . 5 8 , 0 . 9 1}]$ \\
Total events: & 135 & & 176 & & & \\
\end{tabular}

Heterogeneity: $\mathrm{Chi}^{2}=2.92, \mathrm{df}=5(\mathrm{P}=0.71) ; \mathrm{I}^{2}=0 \%$

Test for overall effect: $\mathrm{Z}=2.75(\mathrm{P}=0.006)$

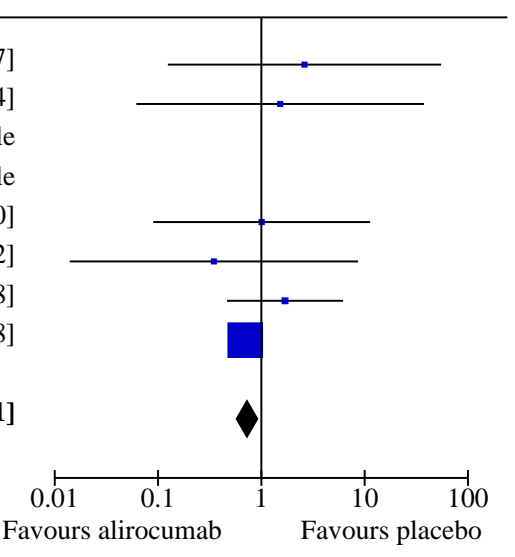

Test for subgroup differences: Not applicable

\section{Analysis 1.5. Comparison 1: Alirocumab versus placebo, Outcome 5: Influenza}

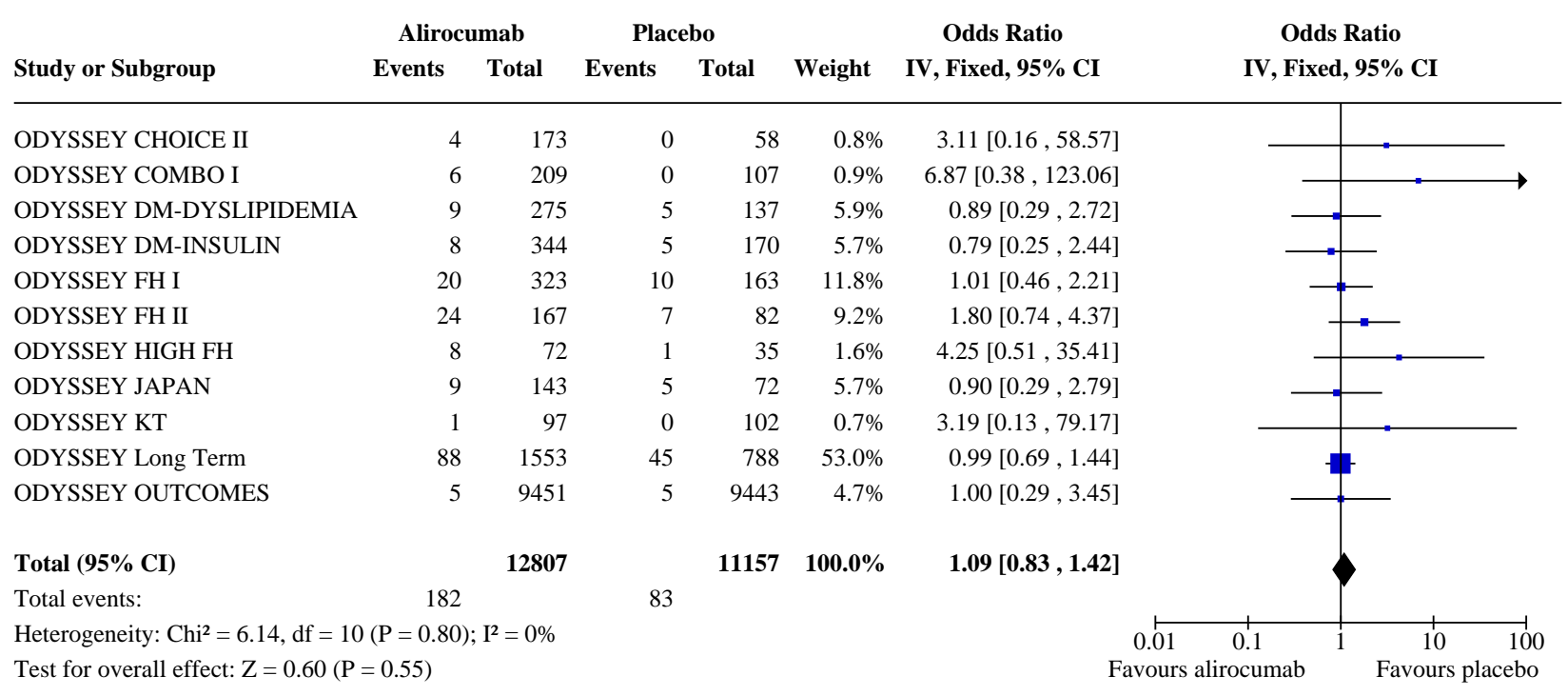


Analysis 1.6. Comparison 1: Alirocumab versus placebo, Outcome 6: Type 2 diabetes mellitus

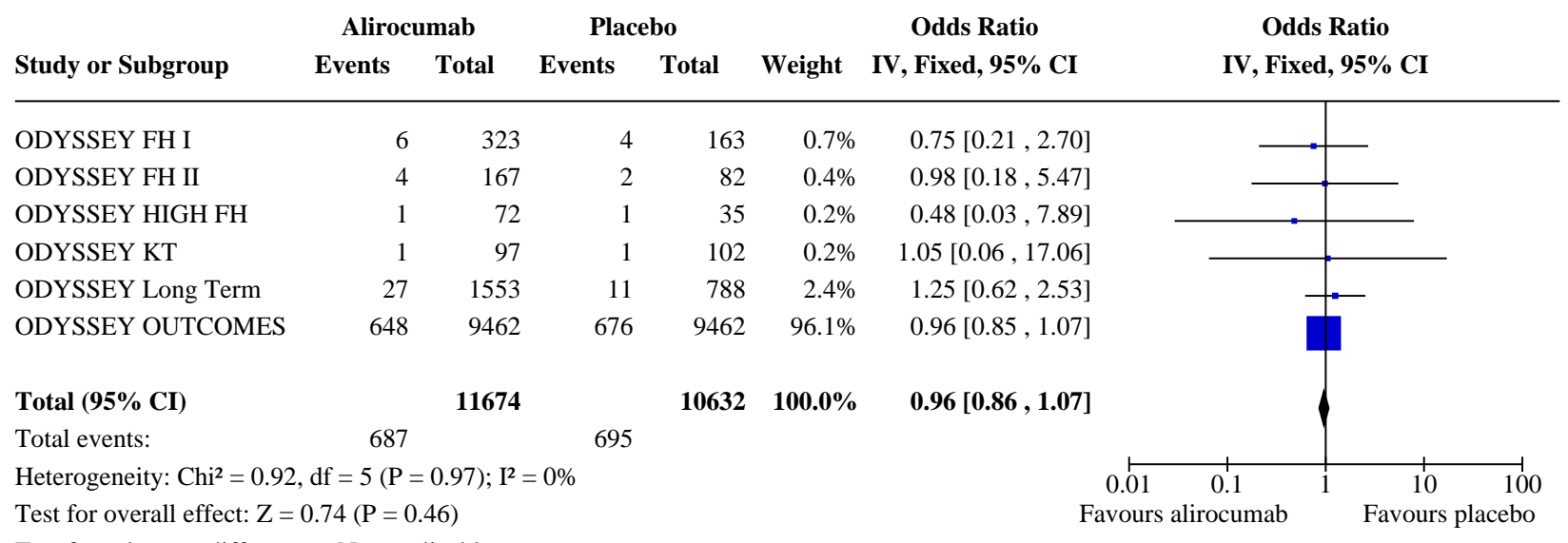

Test for subgroup differences: Not applicable

\section{Analysis 1.7. Comparison 1: Alirocumab versus placebo, Outcome 7: Any cancer}

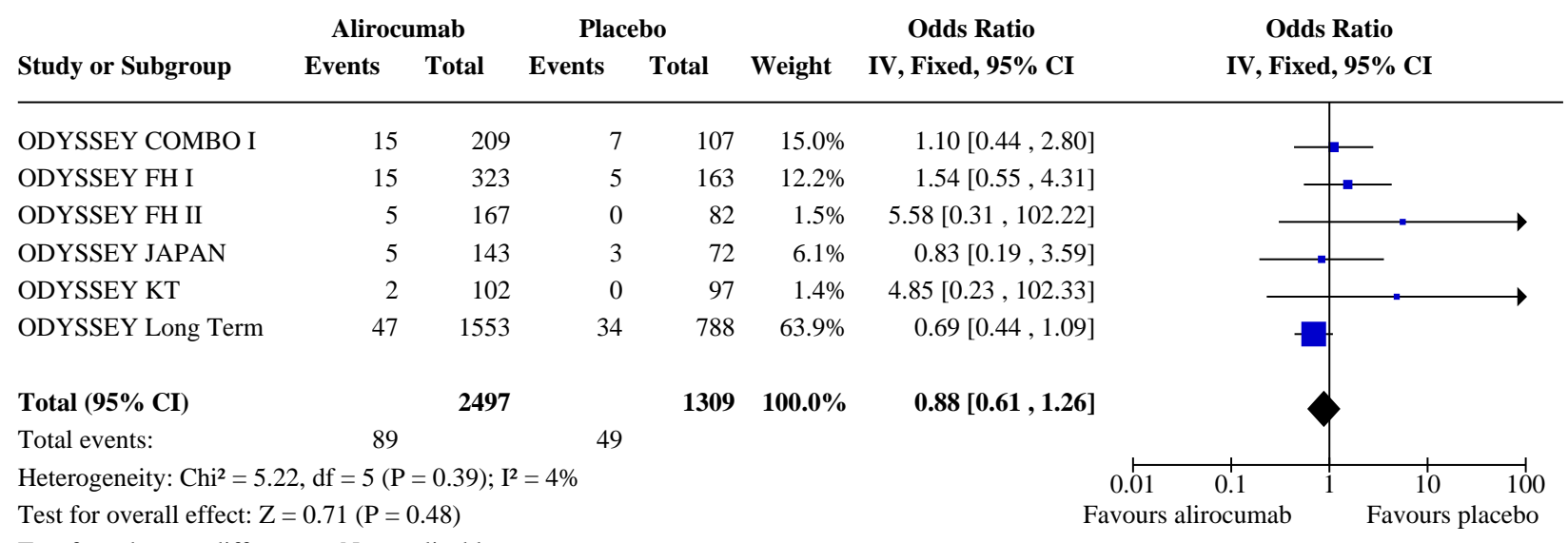




\section{Analysis 1.8. Comparison 1: Alirocumab versus placebo, Outcome 8: Hypertension}

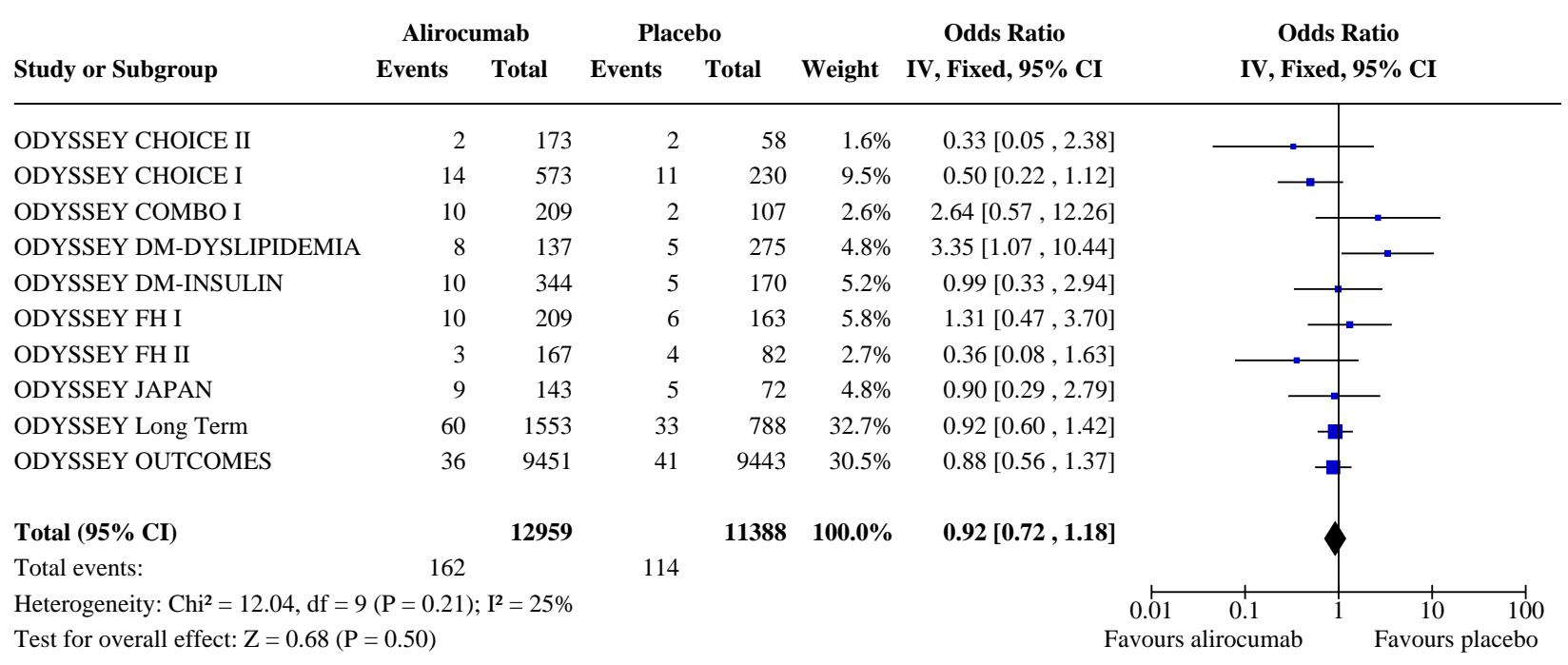

Comparison 2. Evolocumab versus placebo

\begin{tabular}{lllll}
\hline Outcome or subgroup title & $\begin{array}{l}\text { No. of } \\
\text { studies }\end{array}$ & $\begin{array}{l}\text { No. of } \\
\text { partici- } \\
\text { pants }\end{array}$ & Statistical method & Effect size \\
\hline 2.1 Any cardiovascular disease & 3 & 29432 & Odds Ratio (IV, Fixed, 95\% Cl) & $0.84[0.78,0.91]$ \\
\hline 2.2 All-cause mortality & 3 & 29432 & Odds Ratio (IV, Fixed, 95\% Cl) & $1.04[0.91,1.19]$ \\
\hline 2.3 Any myocardial infarction & 3 & 29432 & Odds Ratio (IV, Fixed, 95\% Cl) & $0.72[0.64,0.82]$ \\
\hline 2.4 Any stroke & 2 & 28531 & Odds Ratio (IV, Fixed, 95\% Cl) & $0.79[0.65,0.94]$ \\
\hline 2.5 Influenza & 1 & 901 & Odds Ratio (IV, Fixed, 95\% Cl) & $1.21[0.69,2.11]$ \\
\hline 2.6 Type 2 diabetes mellitus & 3 & 29433 & Odds Ratio (IV, Fixed, 95\% Cl) & $1.05[0.94,1.17]$ \\
\hline
\end{tabular}

Analysis 2.1. Comparison 2: Evolocumab versus placebo, Outcome 1: Any cardiovascular disease

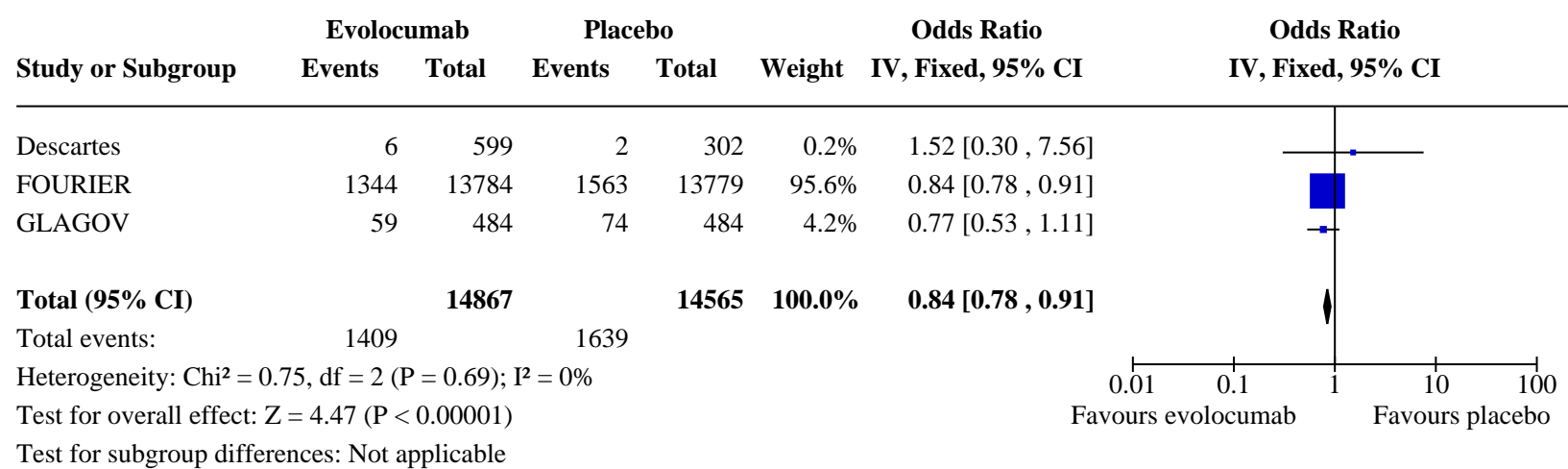


Analysis 2.2. Comparison 2: Evolocumab versus placebo, Outcome 2: All-cause mortality

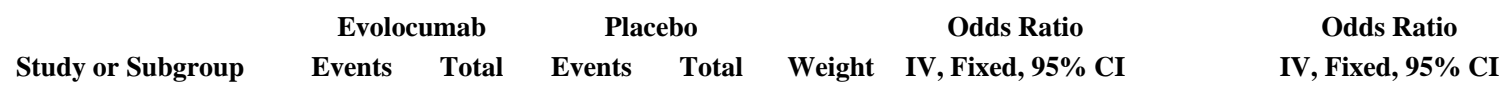

\begin{tabular}{|c|c|c|c|c|c|c|c|}
\hline Descartes & 2 & 599 & 0 & 302 & $0.2 \%$ & $2.53[0.12,52.89]$ & \\
\hline FOURIER & 444 & 13784 & 426 & 13779 & $99.0 \%$ & $1.04[0.91,1.19]$ & \\
\hline GLAGOV & 3 & 484 & 4 & 484 & $0.8 \%$ & $0.75[0.17,3.36]$ & T. \\
\hline Total $(95 \%$ CI $)$ & & 14867 & & 14565 & $100.0 \%$ & $1.04[0.91,1.19]$ & 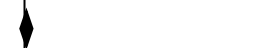 \\
\hline Total events: & 449 & & 430 & & & & \\
\hline \multicolumn{4}{|c|}{ Heterogeneity: $\mathrm{Chi}^{2}=0.51, \mathrm{df}=2(\mathrm{P}=0.77) ; \mathrm{I}^{2}=0 \%$} & & & $0.01 \quad 0.1$ & $10 \quad 100$ \\
\hline \multicolumn{4}{|c|}{ Test for overall effect: $\mathrm{Z}=0.60(\mathrm{P}=0.55)$} & & & Favours evolocumab & Favours placebo \\
\hline
\end{tabular}

Test for subgroup differences: Not applicable

\section{Analysis 2.3. Comparison 2: Evolocumab versus placebo, Outcome 3: Any myocardial infarction}

\begin{tabular}{|c|c|c|c|c|c|c|c|}
\hline & Evol & mab & & & & Odds Ratio & Odds Ratio \\
\hline Study or Subgroup & Events & Total & Events & Total & Weight & IV, Fixed, 95\% CI & IV, Fixed, 95\% CI \\
\hline
\end{tabular}

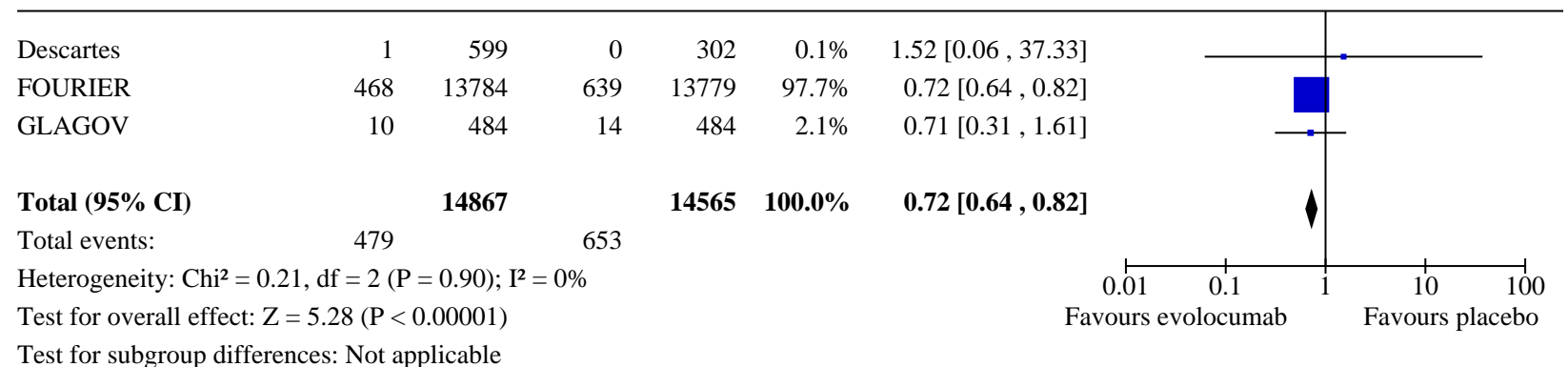

Analysis 2.4. Comparison 2: Evolocumab versus placebo, Outcome 4: Any stroke

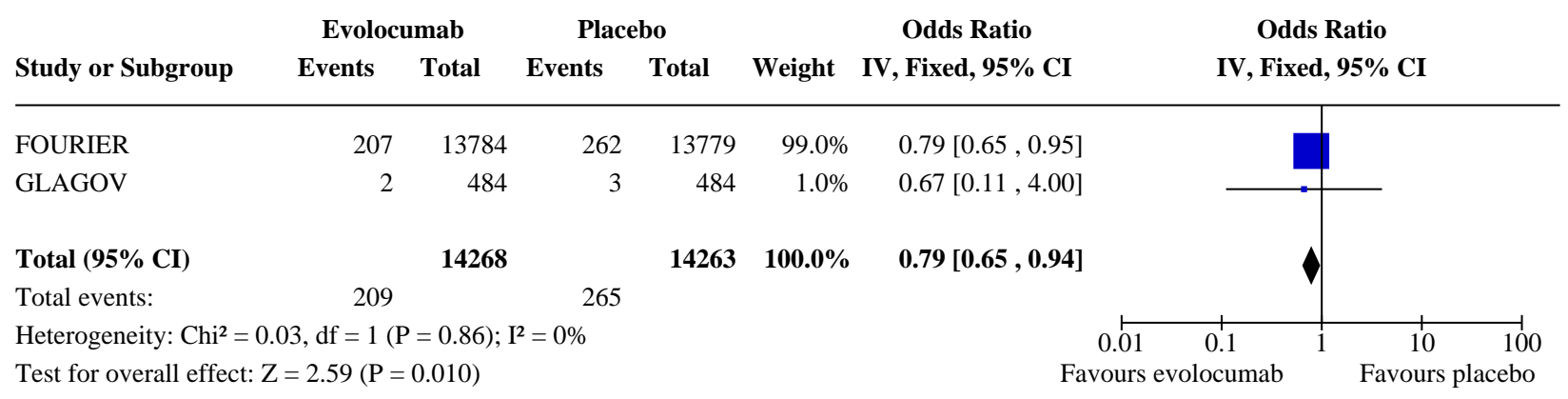


Analysis 2.5. Comparison 2: Evolocumab versus placebo, Outcome 5: Influenza

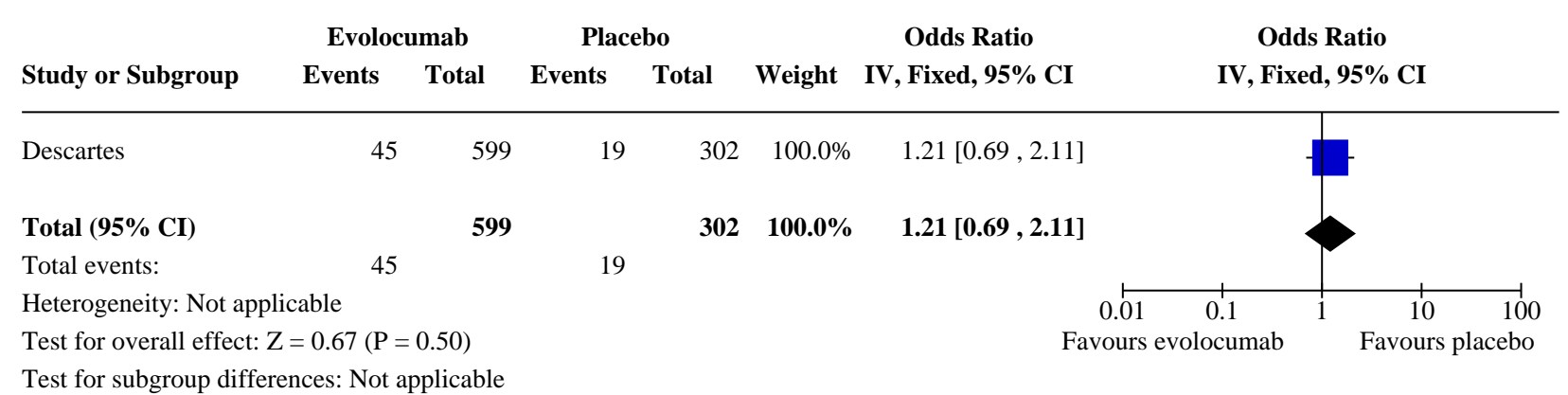

\section{Analysis 2.6. Comparison 2: Evolocumab versus placebo, Outcome 6: Type 2 diabetes mellitus}

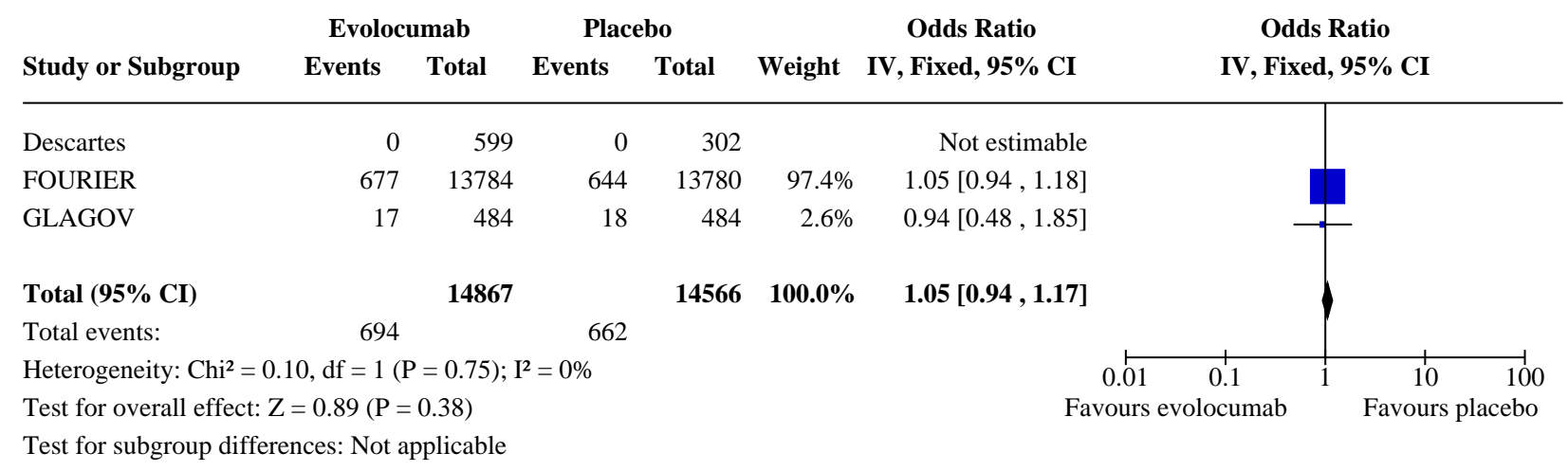

\section{Comparison 3. Alirocumab versus active therapy}

\begin{tabular}{lllll}
\hline Outcome or subgroup title & $\begin{array}{l}\text { No. of } \\
\text { studies }\end{array}$ & $\begin{array}{l}\text { No. of } \\
\text { partici- } \\
\text { pants }\end{array}$ & Statistical method & Effect size \\
\hline 3.1 Any cardiovascular disease & 3 & 1379 & Odds Ratio (M-H, Fixed, 95\% Cl) & $1.37[0.65,2.87]$ \\
\hline 3.2 All-cause mortality & 5 & 1733 & Odds Ratio (IV, Fixed, 95\% Cl) & $0.51[0.18,1.40]$ \\
\hline 3.3 Any myocardial infarction & 5 & 1734 & Odds Ratio (IV, Fixed, 95\% Cl) & $1.45[0.64,3.28]$ \\
\hline 3.4 Any stroke & 5 & 1734 & Odds Ratio (M-H, Fixed, 95\% Cl) & $0.85[0.13,5.61]$ \\
\hline 3.5 Influenza & 4 & 1483 & Odds Ratio (M-H, Fixed, 95\% CI) & $1.72[0.91,3.25]$ \\
\hline 3.6 Type 2 diabetes mellitus & 2 & 660 & Odds Ratio (IV, Fixed, 95\% Cl) & $0.28[0.05,1.55]$ \\
\hline 3.7 Any cancer & 1 & 720 & Odds Ratio (M-H, Fixed, 95\% Cl) & $1.08[0.43,2.69]$ \\
\hline 3.8 Hypertension & 4 & 1630 & Odds Ratio (IV, Fixed, 95\% Cl) & $1.01[0.57,1.79]$ \\
\hline
\end{tabular}


Analysis 3.1. Comparison 3: Alirocumab versus active therapy, Outcome 1: Any cardiovascular disease

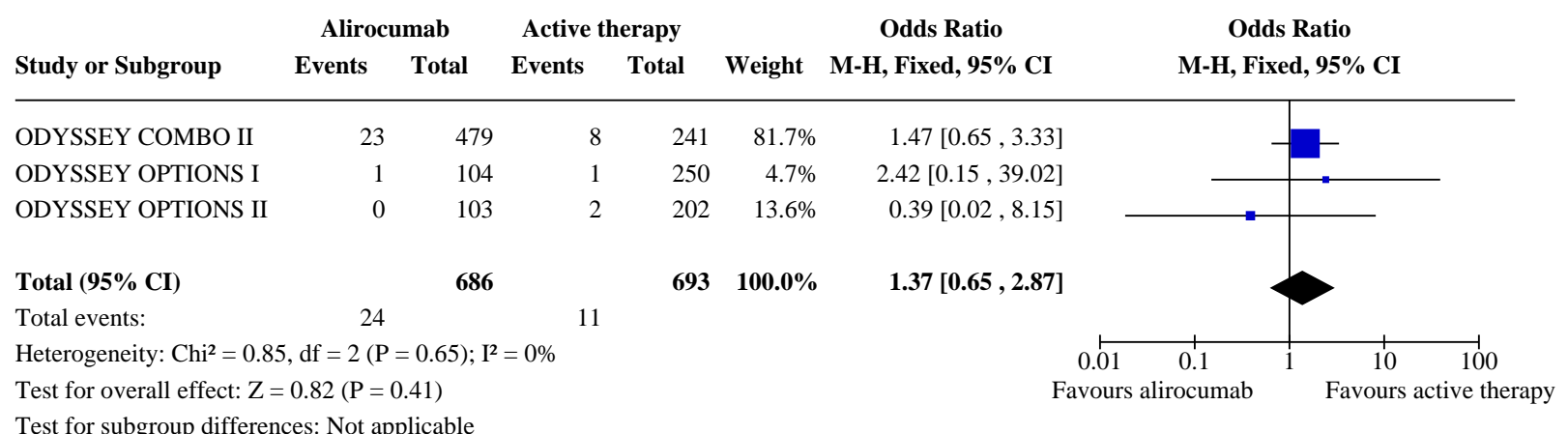

Analysis 3.2. Comparison 3: Alirocumab versus active therapy, Outcome 2: All-cause mortality

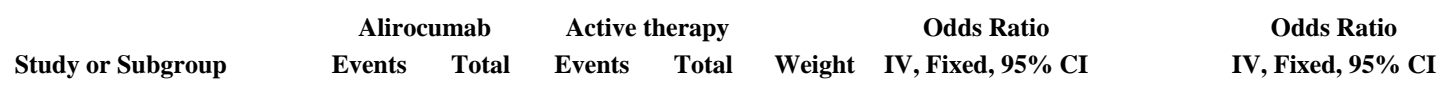

\begin{tabular}{lrrrrrr}
\hline ODYSSEY ALTERNATIVE & 0 & 126 & 0 & 125 & & Not estimable \\
ODYSSEY COMBO II & 6 & 479 & 6 & 241 & $78.9 \%$ & $0.50[0.16,1.56]$ \\
ODYSSEY MONO & 0 & 52 & 0 & 51 & & Not estimable \\
ODYSSEY OPTIONS I & 0 & 104 & 2 & 250 & $11.1 \%$ & $0.48[0.02,9.99]$ \\
ODYSSEY OPTIONS II & 0 & 103 & 1 & 202 & $10.0 \%$ & $0.65[0.03,16.07]$ \\
& & & & & & \\
Total (95\% CI) & & $\mathbf{8 6 4}$ & & $\mathbf{8 6 9}$ & $\mathbf{1 0 0 . 0 \%}$ & $\mathbf{0 . 5 1}[\mathbf{0 . 1 8}, \mathbf{1 . 4 0}]$ \\
Total events: & 6 & & 9 & & &
\end{tabular}

Heterogeneity: $\mathrm{Chi}^{2}=0.03, \mathrm{df}=2(\mathrm{P}=0.99) ; \mathrm{I}^{2}=0 \%$

Test for overall effect: $\mathrm{Z}=1.31(\mathrm{P}=0.19)$

Test for subgroup differences: Not applicable

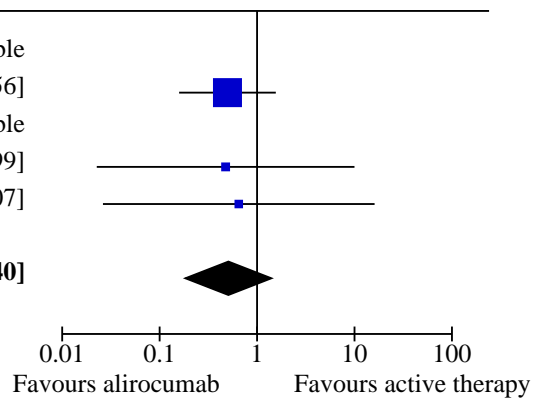

\section{Analysis 3.3. Comparison 3: Alirocumab versus active therapy, Outcome 3: Any myocardial infarction}

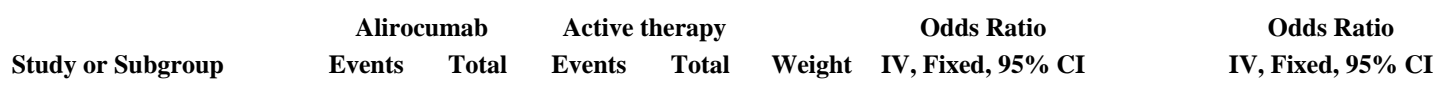

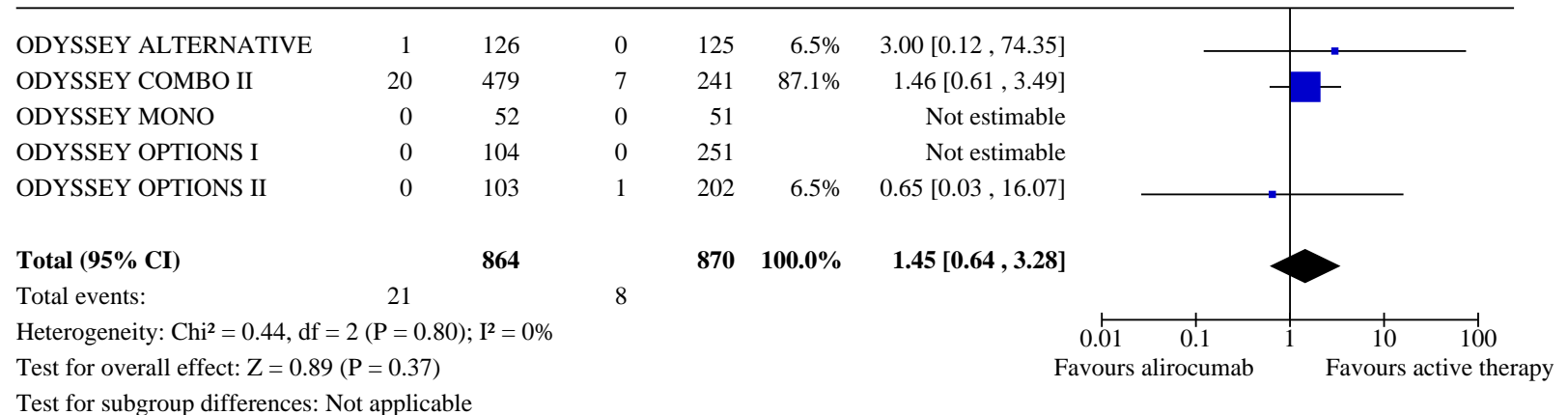


Analysis 3.4. Comparison 3: Alirocumab versus active therapy, Outcome 4: Any stroke

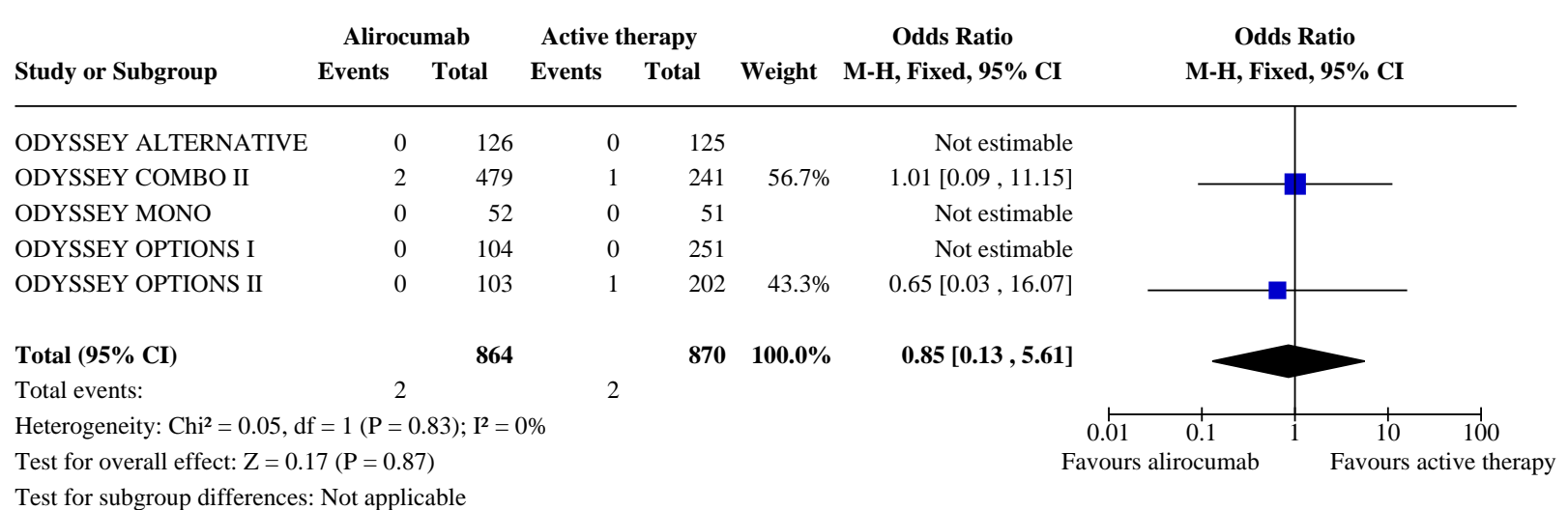

Analysis 3.5. Comparison 3: Alirocumab versus active therapy, Outcome 5: Influenza

\begin{tabular}{|c|c|c|c|c|c|c|c|}
\hline & Aliro & mab & Active & erapy & & Odds Ratio & Odds Ratio \\
\hline Study or Subgroup & Events & Total & Events & Total & Weight & M-H, Fixed, 95\% CI & M-H, Fixed, 95\% CI \\
\hline
\end{tabular}

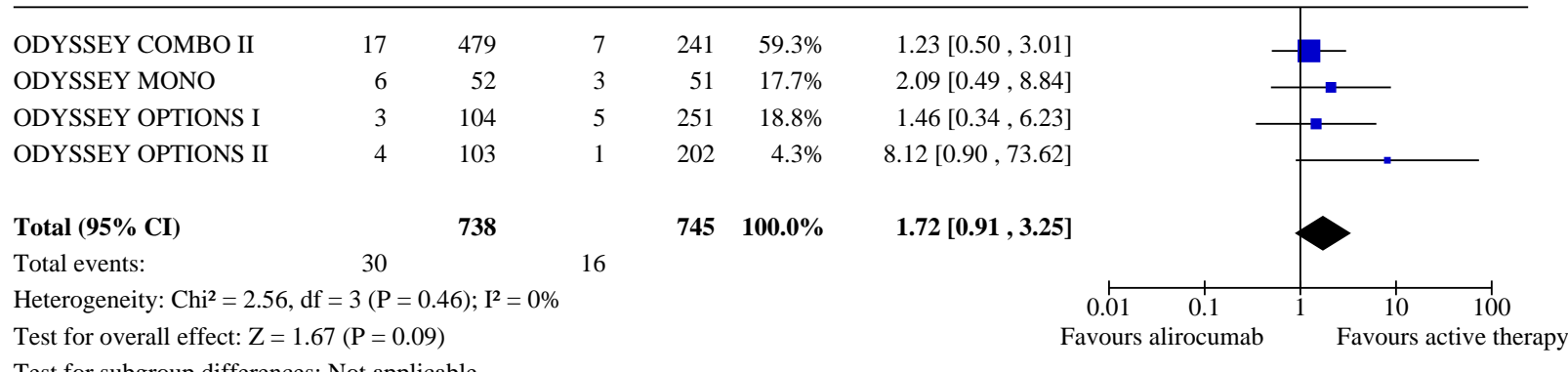

Test for subgroup differences: Not applicable

\section{Analysis 3.6. Comparison 3: Alirocumab versus active therapy, Outcome 6: Type 2 diabetes mellitus}

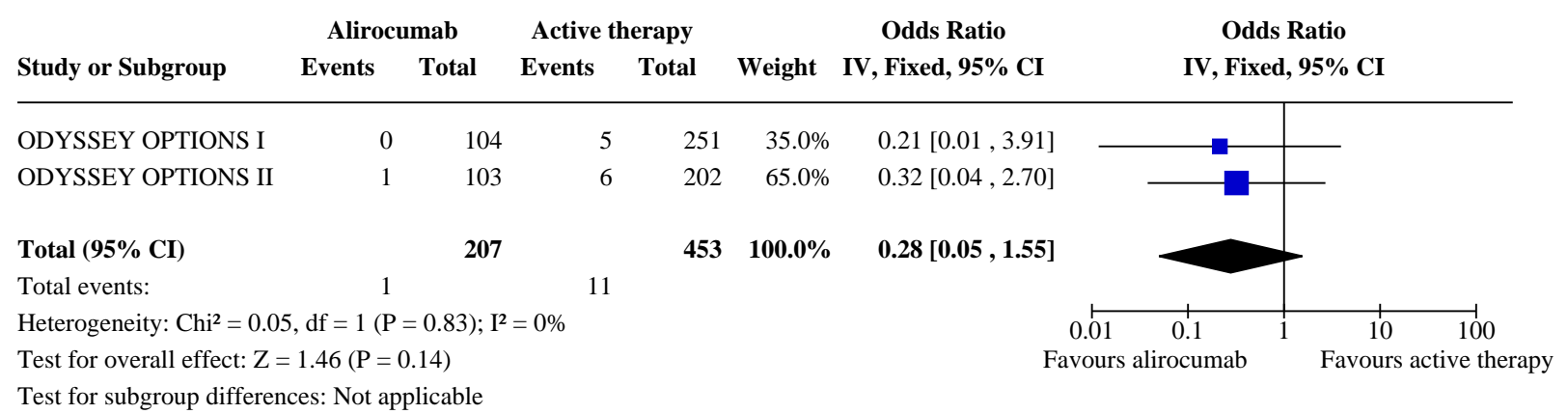


Analysis 3.7. Comparison 3: Alirocumab versus active therapy, Outcome 7: Any cancer

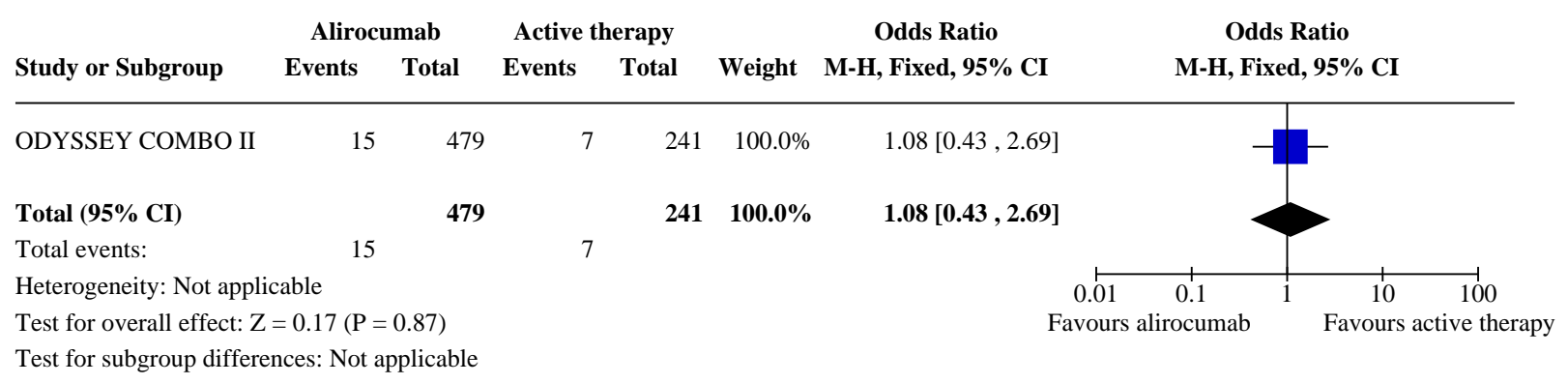

\section{Analysis 3.8. Comparison 3: Alirocumab versus active therapy, Outcome 8: Hypertension}

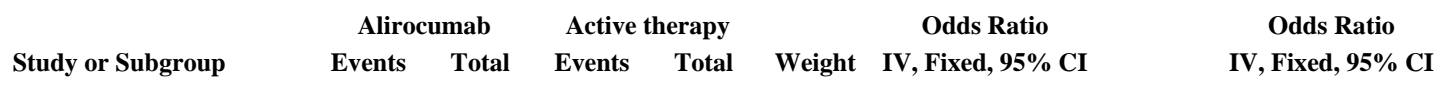

\begin{tabular}{lrrrrrr}
\hline ODYSSEY ALTERNATIVE & 4 & 126 & 4 & 125 & $16.5 \%$ & $0.99[0.24,4.06]$ \\
ODYSSEY COMBO II & 18 & 479 & 10 & 241 & $52.6 \%$ & $0.90[0.41,1.99]$ \\
ODYSSEY OPTIONS I & 5 & 104 & 7 & 250 & $23.9 \%$ & $1.75[0.54,5.66]$ \\
ODYSSEY OPTIONS II & 1 & 103 & 5 & 202 & $7.0 \%$ & $0.39[0.04,3.35]$ \\
& & & & & & \\
$\begin{array}{l}\text { Total (95\% CI) } \\
\text { Total events: }\end{array}$ & 28 & & 26 & & & $\mathbf{8 1 2}$ \\
\hline
\end{tabular}

Heterogeneity: $\mathrm{Chi}^{2}=1.69, \mathrm{df}=3(\mathrm{P}=0.64) ; \mathrm{I}^{2}=0 \%$

Test for overall effect: $\mathrm{Z}=0.04(\mathrm{P}=0.97)$

Test for subgroup differences: Not applicable

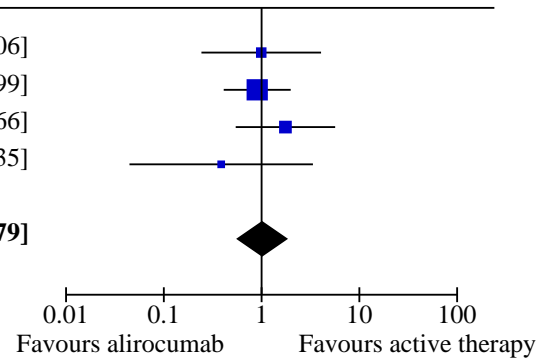

\section{Comparison 4. Evolocumab versus active therapy}

\begin{tabular}{lllll}
\hline Outcome or subgroup title & $\begin{array}{l}\text { No. of } \\
\text { studies }\end{array}$ & $\begin{array}{l}\text { No. of } \\
\text { partici- } \\
\text { pants }\end{array}$ & Statistical method & Effect size \\
\hline 4.1 Any cardiovascular disease & 1 & 218 & Odds Ratio (IV, Fixed, 95\% Cl) & $0.66[0.14,3.04]$ \\
\hline 4.2 All-cause mortality & 3 & 5223 & Odds Ratio (IV, Fixed, 95\% Cl) & $0.43[0.14,1.30]$ \\
\hline 4.3 Any myocardial infarction & 3 & 5003 & Odds Ratio (IV, Fixed, 95\% Cl) & $0.66[0.23,1.85]$ \\
\hline 4.4 Influenza & 3 & 5223 & Odds Ratio (IV, Fixed, 95\% Cl) & $1.22[0.88,1.70]$ \\
\hline 4.5 Type 2 diabetes mellitus & 2 & 5005 & Odds Ratio (M-H, Fixed, 95\% Cl) & $3.52[0.18,68.33]$ \\
\hline 4.6 Hypertension & 2 & 5005 & Odds Ratio (IV, Fixed, 95\% Cl) & $1.51[0.06,37.04]$ \\
\hline
\end{tabular}


Analysis 4.1. Comparison 4: Evolocumab versus active therapy, Outcome 1: Any cardiovascular disease

\begin{tabular}{|c|c|c|c|c|c|c|c|}
\hline & Evolo & mab & Active & ierapy & & Odds Ratio & Odds Ratio \\
\hline Study or Subgroup & Events & Total & Events & Total & Weight & IV, Fixed, $95 \%$ CI & IV, Fixed, 95\% CI \\
\hline
\end{tabular}

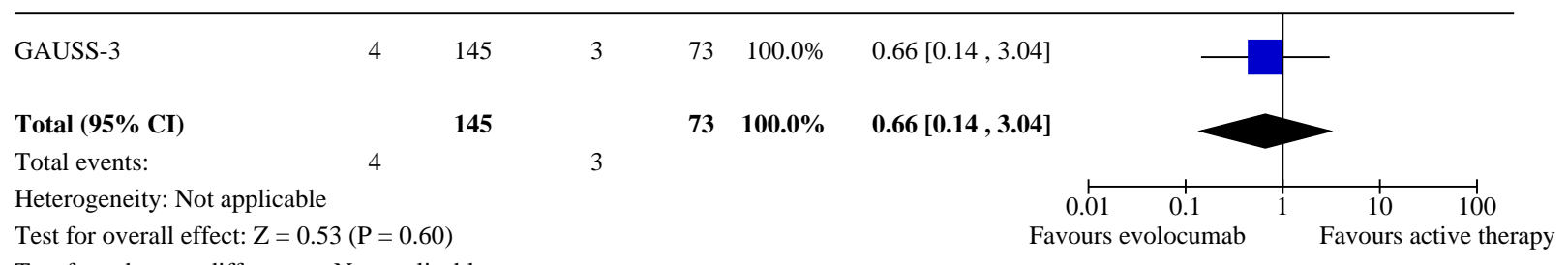

Test for subgroup differences: Not applicable

\section{Analysis 4.2. Comparison 4: Evolocumab versus active therapy, Outcome 2: All-cause mortality}

\begin{tabular}{|c|c|c|c|c|c|c|c|}
\hline & Evolo & mab & Active & erapy & & Odds Ratio & Odds Ratio \\
\hline Study or Subgroup & Events & Total & Events & Total & Weight & IV, Fixed, $95 \%$ CI & IV, Fixed, 95\% CI \\
\hline
\end{tabular}

\begin{tabular}{lrrrrrr}
\hline GAUSS-3 & 0 & 145 & 0 & 73 & & Not estimable \\
OSLER-1 & 1 & 882 & 2 & 442 & $21.1 \%$ & $0.25[0.02,2.76]$ \\
OSLER-2 & 5 & 2454 & 5 & 1227 & $78.9 \%$ & $0.50[0.14,1.73]$ \\
& & & & & & \\
Total (95\% CI) & & $\mathbf{3 4 8 1}$ & & $\mathbf{1 7 4 2}$ & $\mathbf{1 0 0 . 0 \%}$ & $\mathbf{0 . 4 3}[\mathbf{0 . 1 4}, \mathbf{1 . 3 0}]$ \\
Total events: & 6 & & 7 & & &
\end{tabular}

Heterogeneity: $\mathrm{Chi}^{2}=0.25, \mathrm{df}=1(\mathrm{P}=0.62) ; \mathrm{I}^{2}=0 \%$

Test for overall effect: $\mathrm{Z}=1.49(\mathrm{P}=0.14)$

Test for subgroup differences: Not applicable

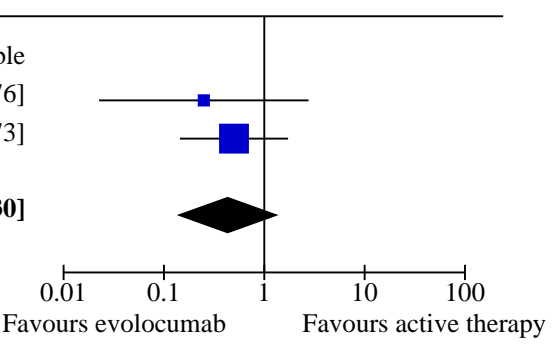

\section{Analysis 4.3. Comparison 4: Evolocumab versus active therapy, Outcome 3: Any myocardial infarction}

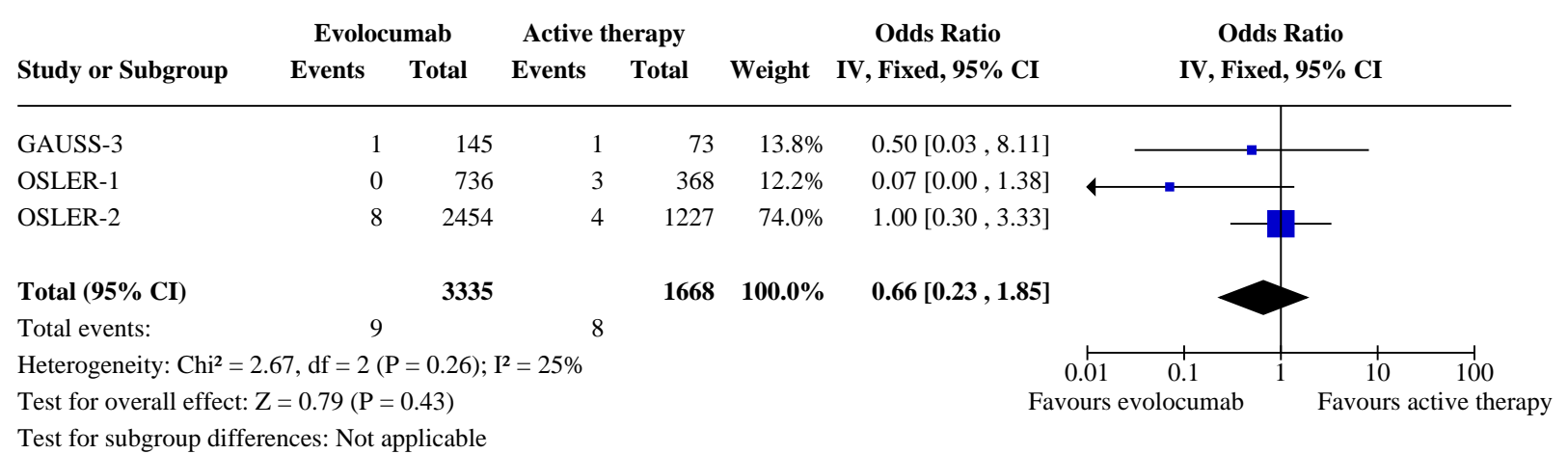


Analysis 4.4. Comparison 4: Evolocumab versus active therapy, Outcome 4: Influenza

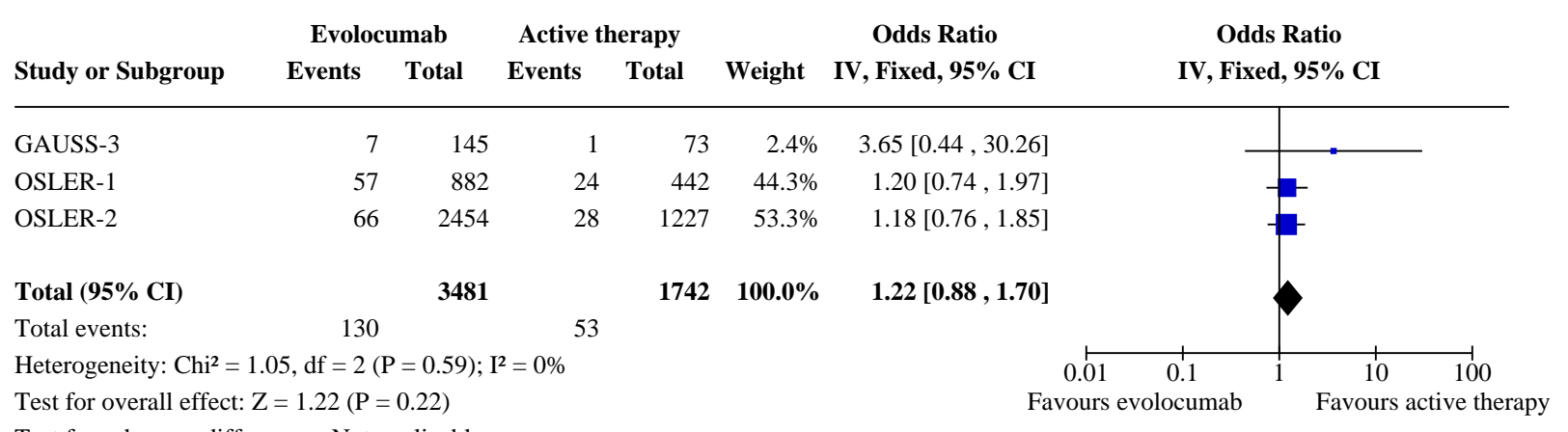

Test for subgroup differences: Not applicable

Analysis 4.5. Comparison 4: Evolocumab versus active therapy, Outcome 5: Type 2 diabetes mellitus

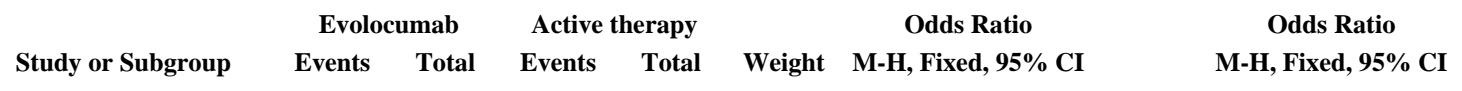

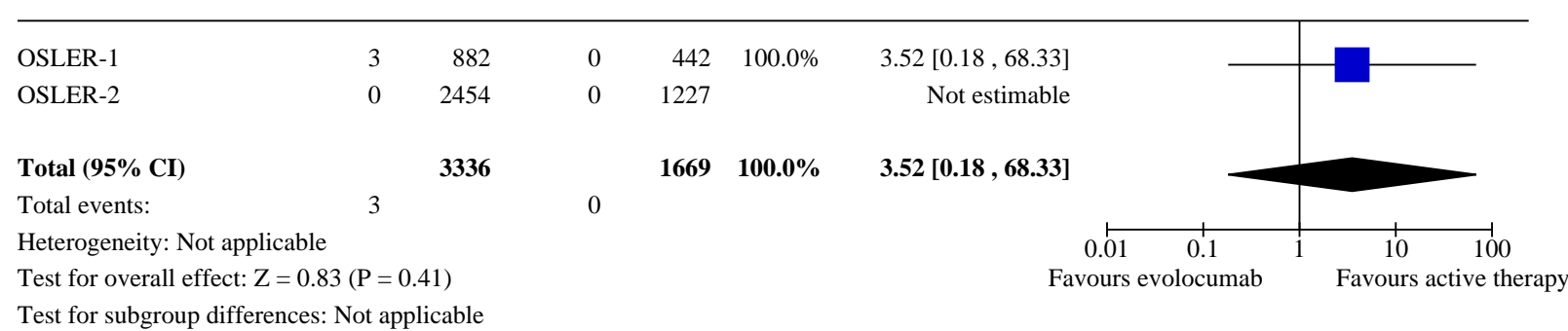

\section{Analysis 4.6. Comparison 4: Evolocumab versus active therapy, Outcome 6: Hypertension}

\begin{tabular}{|c|c|c|c|c|c|c|c|}
\hline \multirow[b]{2}{*}{ Study or Subgroup } & \multicolumn{2}{|c|}{ Evolocumab } & \multicolumn{2}{|c|}{ Active therapy } & \multicolumn{2}{|r|}{ Odds Ratio } & Odds Ratio \\
\hline & Events & Total & Events & Total & Weight & IV, Fixed, 95\% CI & IV, Fixed, $95 \%$ CI \\
\hline
\end{tabular}

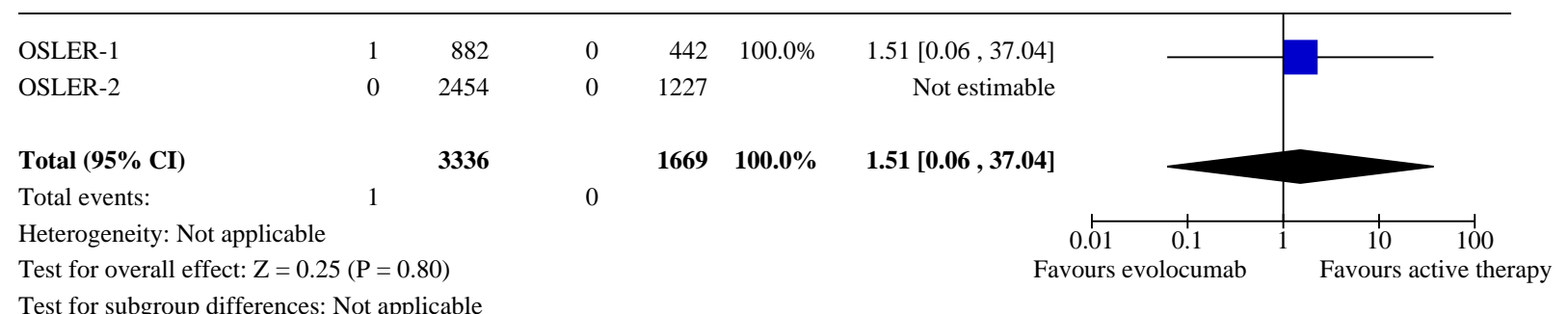

\section{ADDITIONAL TABLES}




\begin{tabular}{|c|c|c|c|c|c|c|c|}
\hline \multirow[t]{2}{*}{ Outcome } & \multirow{2}{*}{$\begin{array}{l}\text { Number of } \\
\text { studies }\end{array}$} & \multicolumn{2}{|l|}{ Intervention } & \multicolumn{2}{|c|}{ Comparison } & \multirow[t]{2}{*}{ Fixed-effectOR $(95 \% \mathrm{Cl})$} & \multirow{2}{*}{$\begin{array}{l}\text { Fixed-effect } \\
\text { RD }(95 \% \mathrm{CI})\end{array}$} \\
\hline & & Events & $\begin{array}{l}\text { Avail- } \\
\text { able partici- } \\
\text { pants }\end{array}$ & Events & $\begin{array}{l}\text { Available } \\
\text { participants }\end{array}$ & & \\
\hline Any CVD & 10 & 1411 & 12,770 & 1531 & 11,098 & $0.87(0.80$ to 0.94$)$ & $-0.02(-0.02$ to -0.01$)$ \\
\hline $\begin{array}{l}\text { All-cause } \\
\text { mortality }\end{array}$ & 12 & 352 & 13,390 & 408 & 11,407 & 0.83 (0.72 to 0.96$)$ & $-0.01(-0.01$ to -0.001$)$ \\
\hline Any MI & 9 & 1221 & 12,369 & 1372 & 10,983 & $0.86(0.79$ to 0.94$)$ & $-0.02(-0.02$ to -0.01$)$ \\
\hline Any stroke & 8 & 135 & 12,024 & 173 & 10,811 & 0.73 (0.58 to 0.91$)$ & $-0.004(-0.007$ to -0.001$)$ \\
\hline Influenza & 11 & 182 & 12,807 & 83 & 11,157 & 1.09 (0.83 to 1.42 ) & $0.01(-0.01$ to 0.02$)$ \\
\hline $\begin{array}{l}\text { Type } 2 \text { dia- } \\
\text { betes melli- } \\
\text { tus }\end{array}$ & 6 & 687 & 11,674 & 695 & 10,632 & 0.96 (0.86 to 1.07 ) & $-0.002(-0.009$ to 0.004$)$ \\
\hline Any cancer & 6 & 88 & 2,497 & 49 & 1,309 & $0.88(0.61$ to 1.26$)$ & $-0.003(-0.02$ to 0.01$)$ \\
\hline $\begin{array}{l}\text { Hyperten- } \\
\text { sion }\end{array}$ & 10 & 162 & 12,959 & 114 & 11,388 & $0.92(0.72$ to 1.18$)$ & $-0.003(-0.01$ to 0.01$)$ \\
\hline \multicolumn{8}{|c|}{ Cl: confidence interval; CVD: cardiovascular disease; MI: myocardial infarction; OR: odds ratio; RD: risk difference. } \\
\hline \multirow[t]{2}{*}{ Outcome } & \multirow{2}{*}{$\begin{array}{l}\text { Number of } \\
\text { studies }\end{array}$} & \multicolumn{2}{|l|}{ Intervention } & \multicolumn{2}{|c|}{ Comparison } & \multirow{2}{*}{$\begin{array}{l}\text { Fixed-effect } \\
\text { OR }(95 \% \mathrm{CI})\end{array}$} & \multirow{2}{*}{$\begin{array}{l}\text { Fixed-effect } \\
\text { RD }(95 \% \mathrm{Cl})\end{array}$} \\
\hline & & Events & $\begin{array}{l}\text { Available } \\
\text { participants }\end{array}$ & Events & $\begin{array}{l}\text { Available } \\
\text { participants }\end{array}$ & & \\
\hline Any CVD & 3 & 1409 & 14,867 & 1639 & 14,565 & 0.84 (0.78 to 0.91$)$ & $-0.016(-0.023$ to -0.009$)$ \\
\hline $\begin{array}{l}\text { All-cause mor- } \\
\text { tality }\end{array}$ & 3 & 449 & 14,867 & 430 & 14,565 & 1.04 (0.91 to 1.19$)$ & $0.001(-0.003$ to 0.005$)$ \\
\hline Any MI & 3 & 479 & 14,867 & 653 & 14,565 & 0.72 (0.64 to 0.82 ) & $-0.012(-0.016$ to -0.008$)$ \\
\hline
\end{tabular}




\begin{tabular}{|c|c|c|c|c|c|c|c|}
\hline Any stroke & 2 & 209 & 14,268 & 265 & 14,263 & 0.79 (0.65 to 0.94$)$ & $-0.004(-0.007$ to -0.001$)$ \\
\hline Influenza & 1 & 45 & 599 & 19 & 302 & 1.21 (0.69 to 2.11$)$ & $0.012(-0.026$ to 0.045$)$ \\
\hline $\begin{array}{l}\text { Type } 2 \text { dia- } \\
\text { betes mellitus }\end{array}$ & 3 & 694 & 14,867 & 662 & 14,566 & 1.05 (0.94 to 1.17$)$ & $0.003(-0.004$ to 0.011$)$ \\
\hline Any cancer & 0 & - & - & - & - & Not reported & Not reported \\
\hline Hypertension & 0 & - & - & - & - & Not reported & Not reported \\
\hline \multicolumn{8}{|c|}{$\mathrm{Cl}$ : confidence interval; CVD: cardiovascular disease; MI: myocardial infarction; OR: odds ratio; RD: risk difference. } \\
\hline \multirow[t]{2}{*}{ Outcome } & \multirow{2}{*}{$\begin{array}{l}\text { Number of } \\
\text { studies }\end{array}$} & \multicolumn{2}{|c|}{ Intervention } & \multicolumn{2}{|c|}{ Comparison } & \multirow{2}{*}{$\begin{array}{l}\text { Fixed-effect } \\
\text { OR }(95 \% \mathrm{Cl})\end{array}$} & \multirow{2}{*}{$\begin{array}{l}\text { Fixed-effect } \\
\text { RD }(95 \% \mathrm{Cl})\end{array}$} \\
\hline & & Events & $\begin{array}{l}\text { Available } \\
\text { participants }\end{array}$ & Events & $\begin{array}{l}\text { Available } \\
\text { participants }\end{array}$ & & \\
\hline Any CVD & 3 & 24 & 686 & 11 & 693 & 1.37 (0.65 to 2.87$)$ & $0.009(-0.008$ to 0.027$)$ \\
\hline $\begin{array}{l}\text { All-cause } \\
\text { mortality }\end{array}$ & 5 & 6 & 864 & 9 & 869 & 0.51 (0.18 to 1.40$)$ & $-0.006(-0.015$ to 0.003$)$ \\
\hline Any MI & 5 & 21 & 864 & 8 & 870 & 1.45 (0.64 to 3.28$)$ & $0.007(-0.006$ to 0.020$)$ \\
\hline Any stroke & 5 & 2 & 864 & 2 & 870 & 0.85 (0.13 to 5.61$)$ & $0.000(-0.005$ to 0.005$)$ \\
\hline Influenza & 4 & 30 & 738 & 16 & 745 & 1.72 (0.91 to 3.25$)$ & $0.017(-0.001$ to 0.036$)$ \\
\hline $\begin{array}{l}\text { Type } 2 \text { dia- } \\
\text { betes melli- } \\
\text { tus }\end{array}$ & 2 & 1 & 207 & 11 & 453 & 0.28 (0.05 to 1.55$)$ & $-0.019(-0.041$ to 0.002$)$ \\
\hline Any cancer & 1 & 15 & 479 & 7 & 241 & 1.08 (0.43 to 2.69 ) & $0.002(-0.030$ to 0.027$)$ \\
\hline $\begin{array}{l}\text { Hyperten- } \\
\text { sion }\end{array}$ & 4 & 28 & 812 & 26 & 818 & 1.01 (0.57 to 1.79$)$ & $0.003(-0.015$ to 0.020$)$ \\
\hline
\end{tabular}


Table 4. Summary results - evolocumab compared with alternative lipid-lowering treatments

\begin{tabular}{|c|c|c|c|c|c|c|c|}
\hline \multirow[t]{2}{*}{ Outcome } & \multirow{2}{*}{$\begin{array}{l}\text { Number of } \\
\text { studies }\end{array}$} & \multicolumn{2}{|c|}{ Intervention } & \multicolumn{2}{|c|}{ Comparison } & \multirow{2}{*}{$\begin{array}{l}\text { Fixed-effect } \\
\text { OR }(95 \% \mathrm{Cl})\end{array}$} & \multirow{2}{*}{$\begin{array}{l}\text { Fixed-effect } \\
\text { RD }(95 \% \mathrm{Cl})\end{array}$} \\
\hline & & Events & $\begin{array}{l}\text { Available } \\
\text { participants }\end{array}$ & Events & $\begin{array}{l}\text { Available } \\
\text { participants }\end{array}$ & & \\
\hline Any CVD & 1 & 4 & 145 & 3 & 73 & 0.66 (0.14 to 3.04$)$ & $-0.01(-0.07$ to 0.04$)$ \\
\hline $\begin{array}{l}\text { All-cause mortal- } \\
\text { ity }\end{array}$ & 3 & 6 & 3481 & 7 & 1742 & $0.43(0.14$ to 1.30$)$ & $-0.00(-0.01$ to 0.01$)$ \\
\hline Any MI & 3 & 9 & 3335 & 8 & 1668 & 0.66 (0.23 to 1.85 ) & $-0.00(-0.00$ to 0.00$)$ \\
\hline Any stroke & 2 & 0 & 2599 & 0 & 1300 & NA & NA \\
\hline Influenza & 3 & 130 & 3481 & 53 & 1742 & 1.22 (0.88 to 1.70$)$ & 0.01 (-0.00 to 0.02$)$ \\
\hline $\begin{array}{l}\text { Type } 2 \text { diabetes } \\
\text { mellitus }\end{array}$ & 2 & 3 & 3336 & 0 & 1669 & 3.52 (0.18 to 68.33$)$ & 0.001 (-0.001 to 0.002$)$ \\
\hline Any cancer & - & - & - & - & - & NA & NA \\
\hline Hypertension & 2 & 1 & 3336 & 0 & 1669 & 1.51 (0.06 to 37.04$)$ & $0.00(-0.00$ to 0.01$)$ \\
\hline
\end{tabular}

Cl: confidence interval; CVD: cardiovascular disease; MI: myocardial infarction; NA: not available; OR: odds ratio; RD: risk difference. 


\section{AP PEN DICES}

\section{Appendix 1. Search strategies}

\section{MEDLINE search strategy}

1. exp antibodies, monoclonal/

2. monoclonal antibod ${ }^{*}$.tw.

3. $M A B^{\star}$.tw.

4. evolocumab.tw.

5. amg 145.tw.

6. amg145.tw.

7. alirocumab.tw.

8. regn 727.tw.

9. regn727.tw.

10. sar 236553.tw.

11. sar236553.tw.

12. 1D05-IgG2.tw.

13. LGT209.tw.

14. RG7652.tw.

15. Bococizumab.tw.

16. "pf 04950615".tw.

17. pf04950615.tw.

18. rn 316.tw.

19. rn316.tw.

20. or/1-19

21. exp Proprotein Convertases/

22. proprotein convertase ${ }^{\star} . \mathrm{tw}$.

23. pro-protein convertase ${ }^{\star} . t w$.

24. pcsk9.tw.

25. serine proteinase ${ }^{\star} . t w$.

26. or/21-25

27. exp Cardiovascular Diseases/

28. cardio*.tw.

29. cardia*.tw.

30. heart ${ }^{\star} . t w$.

31. coronary ${ }^{\star} . t w$.

32. angina*.tw.

33. ventric ${ }^{\star}$. tw.

34. myocard*.tw.

35. pericard ${ }^{*}$. tw.

36. isch?em ${ }^{\star}$. tw.

37. emboli*.tw.

38. arrhythmi*.tw.

39. thrombo*.tw.

40. atrial fibrillat*.tw.

41. tachycardi ${ }^{\star}$. tw.

42. endocardi ${ }^{\star}$.tw.

43. (sick adj sinus).tw.

44. exp Stroke/

45. (stroke or stokes).tw.

46. cerebrovasc ${ }^{\star}$. tw.

47. cerebral vascular.tw.

48. apoplexy.tw.

49. (brain adj2 accident $\left.{ }^{\star}\right)$.tw.

50. ((brain* or cerebral or lacunar) adj2 infarct $\left.{ }^{\star}\right)$.tw.

51. exp Hyperlipidemias/

52. hyperlipid*.tw.

53. hyperlip?emia*.tw.

54. hypercholesterol ${ }^{*}$.tw.

55. hypercholester?emia*.tw. 
56. hyperlipoprotein?emia*.tw.

57. hypertriglycerid?emia*.tw.

58. exp Arteriosclerosis/

59. $\exp$ Cholesterol/

60. cholesterol.tw.

61. "coronary risk factor* ".tw.

62. exp Cognition/

63. exp dementia/

64. cognitive function ${ }^{\star}$. tw.

65. dementia.tw.

66. alzheimer ${ }^{\star}$.tw.

67. or/27-66

68. 20 and 26 and 67

69. randomized controlled trial.pt.

70. controlled clinical trial.pt.

71. randomized.ab.

72. placebo.ab.

73. drug therapy.fs.

74. randomly.ab.

75. trial.ab.

76. groups.ab.

77.69 or 70 or 71 or 72 or 73 or 74 or 75 or 76

78. exp animals/ not humans.sh.

79. 77 not 78

80.68 and 79

81. limit 80 to $y r=" 2005$-Current"

\section{CENTRAL search strategy}

\#1 MeSH descriptor: [Antibodies, Monoclonal] explode all trees

\#2 monoclonal next antibod*

\#3 MAB*

\#4 evolocumab

\#5 "amg 145" or amg145

\#6 alirocumab

\#7 "regn 727" or regn727 or "sar 236553" or sar236553 or 1D05-IgG2 or LGT209 or RG7652

\#8 Bococizumab

\#9 "pf 04950615 " or pf04950615 or "rn 316" or rn316

$\# 10 \# 1$ or \#2 or \#3 or \#4 or \#5 or \#6 or \#7 or \#8 or \#9

\#11 MeSH descriptor: [Proprotein Convertases] explode all trees

\#12 proprotein next convertase*

\#13 pro-protein next convertase*

\#14 pcsk9

\#15 serine next proteinase*

$\# 16 \# 11$ or \#12 or \#13 or \#14 or \#15

\#17 MeSH descriptor: [Cardiovascular Diseases] explode all trees

\#18 cardio*

\#19 cardia*

PCSK9 monoclonal antibodies for the primary and secondary prevention of cardiovascular disease (Review) 
\#20 heart*

\#21 coronary*

\#22 angina*

\#23 ventric*

\#24 myocard*

\#25 pericard ${ }^{\star}$

\#26 isch?em*

\#27 emboli*

\#28 arrhythmi ${ }^{\star}$

\#29 thrombo*

\#30 atrial next fibrillat*

\#31 tachycardi*

\#32 endocardi ${ }^{\star}$

\#33 (sick next sinus)

\#34 MeSH descriptor: [Stroke] explode all trees

\#35 (stroke or stokes)

\#36 cerebrovasc*

\#37 cerebral next vascular

\#38 apoplexy

\#39 (brain near/2 accident ${ }^{\star}$ )

\#40 ((brain* or cerebral or lacunar) near/2 infarct* $\left.{ }^{\star}\right)$

\#41 MeSH descriptor: [Hyperlipidemias] explode all trees

\#42 hyperlipid*

\#43 hyperlip?emia*

\#44 hypercholesterol ${ }^{*}$

\#45 hypercholester?emia*

\#46 hyperlipoprotein?emia*

\#47 hypertriglycerid?emia*

\#48 MeSH descriptor: [Arteriosclerosis] explode all trees

\#49 MeSH descriptor: [Cholesterol] explode all trees

\#50 cholesterol

\#51 "coronary risk factor ${ }^{\star "}$

\#52 MeSH descriptor: [Cognition] explode all trees

\#53 MeSH descriptor: [Dementia] explode all trees

\#54 cognitive next function*

PCSK9 monoclonal antibodies for the primary and secondary prevention of cardiovascular disease (Review) 
\#55 dementia

\#56 alzheimer*

$\# 57 \# 17$ or \#18 or \#19 or \#20 or \#21 or \#22 or \#23 or \#24 or \#25 or \#26 or \#27 or \#28 or \#29 or \#30 or \#31 or \#32 or \#33 or \#34 or \#35 or \#36 or $\# 37$ or \#38 or \#39 or \#40 or \#41 or \#42 or \#43 or \#44 or \#45 or \#46 or \#47 or \#48 or \#49 or \#50 or \#51 or \#52 or \#53 or \#54 or \#55 or \#56

\#58 \#10 and \#16 and \#57 Publication Year from 2005 to 2019

\section{Embase search strategy}

1. exp monoclonal antibody/

2. monoclonal antibod ${ }^{\star}$. tw.

3. $M A B^{\star}$. tw.

4. evolocumab.tw.

5. amg 145.tw.

6. amg145.tw.

7. alirocumab.tw.

8. regn 727.tw.

9. regn727.tw.

10. sar 236553.tw.

11. sar236553.tw.

12. 1D05-IgG2.tw.

13. LGT209.tw.

14. RG7652.tw.

15. Bococizumab.tw.

16. "pf 04950615".tw.

17. pf04950615.tw.

18. rn 316.tw.

19. rn316.tw.

20. or/1-19

21. exp serine proteinase/

22. proprotein convertase ${ }^{\star} . t w$.

23. pro-protein convertase ${ }^{\star} . \mathrm{tw}$.

24. serine proteinase ${ }^{\star} . t w$.

25. pcsk9.tw.

26. or $/ 21-25$

27. exp cardiovascular disease/

28. cardio*.tw.

29. cardia*.tw. 
30. heart*.tw.

31. coronary ${ }^{\star} . \mathrm{tw}$.

32. angina*.tw.

33. ventric*.tw.

34. myocard ${ }^{\star}$.tw.

35. pericard*.tw.

36. isch?em*.tw.

37. emboli*.tw.

38. arrhythmi ${ }^{\star}$.tw.

39. thrombo*.tw.

40. atrial fibrillat*.tw.

41. tachycardi ${ }^{\star}$. tw.

42. endocardi ${ }^{*}$.tw.

43. (sick adj sinus).tw.

44. exp cerebrovascular disease/

45. (stroke or stokes).tw.

46. cerebrovasc*.tw.

47. cerebral vascular.tw.

48. apoplexy.tw.

49. (brain adj2 accident $\left.{ }^{\star}\right)$.tw.

50. ((brain* or cerebral or lacunar) adj2 infarct $\left.{ }^{\star}\right)$.tw.

51. exp hyperlipidemia/

52. hyperlipid*.tw.

53. hyperlip?emia*.tw.

54. hypercholesterol ${ }^{*} . t w$.

55. hypercholester?emia*.tw.

56. hyperlipoprotein?emia*.tw.

57. hypertriglycerid?emia*.tw.

58. exp Arteriosclerosis/

59. exp Cholesterol/

60. cholesterol.tw.

61. "coronary risk factor ".tw.

62. exp cognition/

63. exp dementia/

64. cognitive function ${ }^{\star}$.tw.

PCSK9 monoclonal antibodies for the primary and secondary prevention of cardiovascular disease (Review) 
65. dementia.tw.

66. alzheimer ${ }^{\star}$. tw.

67. or/27-66

68. 20 and 26 and 67

69. random\$.tw.

70. factorial\$̣.tw.

71. crossover\$.tw.

72. cross over\$.tw.

73. cross-over\$.tw.

74. placebo\$.tw.

75. (doubl\$ adj blind\$).tw.

76. (singl\$ adj blind\$).tw.

77. assign\$.tw.

78. allocat\$.tw.

79. volunteer\$.tw.

80. crossover procedure/

81. double blind procedure/

82. randomized controlled trial/

83. single blind procedure/

84.69 or 70 or 71 or 72 or 73 or 74 or 75 or 76 or 77 or 78 or 79 or 80 or 81 or 82 or 83

85. (animal/ or nonhuman/) not human/

86.84 not 85

87.68 and 86

88. limit 87 to embase

89. limit 88 to $y r=" 2005$-Current"

\section{Web of Science search strategy}

\# 12 \#11 AND \#10

\# 11 TS=((random* or blind ${ }^{\star}$ or allocat ${ }^{\star}$ or assign* or trial* or placebo* or crossover ${ }^{\star}$ or cross-over $\left.\left.^{\star}\right)\right)$

\# 10 \#9 AND \#8 AND \#7

\# 9 TS=("proprotein convertase ${ }^{\star "}$ or "pro-protein convertase ${ }^{\star}$ or pcsk9 or "serine proteinase*")

\# 8 TS=("monoclonal antibod*" or MAB* or evolocumab or "amg 145" or amg145 or alirocumab or "regn 727 " or regn727 or "sar $236553 "$ or sar236553 or 1D05-IgG2 or LGT209 or RG7652 or Bococizumab or "pf 04950615 " or pf04950615 or "rn 316" or rn316)

\# 7 \#6 OR \#5 OR \#4 OR \#3 OR \#2 OR \#1

\# 6 TS=("cognitive function*" or dementia or alzheimer*)

\# 5 TS=(cardio* OR cardia* OR heart* OR coronary ${ }^{\star}$ OR angina* OR ventric ${ }^{\star}$ OR myocard $\left.{ }^{\star}\right)$

PCSK9 monoclonal antibodies for the primary and secondary prevention of cardiovascular disease (Review) 
\# 4 TS=(pericard* OR isch?em* OR emboli* OR arrhythmi* OR thrombo*)

\# 3 TS=("atrial fibrillat*" OR tachycardi ${ }^{\star}$ OR endocardi ${ }^{\star}$ )

\# 2 TS=(stroke OR stokes OR cerebrovasc ${ }^{\star}$ OR cerebral OR apoplexy OR (brain SAME accident $\left.{ }^{\star}\right)$ OR (brain SAME infarct $\left.{ }^{\star}\right)$ )

\# 1 TS=(hyperlipid* OR hyperlip?emia* OR hypercholesterol* OR hypercholester?emia* OR hyperlipoprotein?emia* OR hypertriglycerid? emia*)

Clinical trials registers search terms

PCSK9 OR alirocumab OR evolocumab

WHAT'S NEW

\begin{tabular}{lll}
\hline Date & Event & Description \\
\hline 20 August 2020 & $\begin{array}{l}\text { New citation required and conclusions } \\
\text { have changed }\end{array}$ & $\begin{array}{l}\text { Results and conclusion stratified per compound (alirocumab } \\
\text { and evolocumab) and comparison (active treatment or placebo), } \\
\text { finding higher certainty of evidence for placebo comparisons } \\
\text { than against active treatment. After removing trials evaluating } \\
\text { the terminated compound bococizumab (three) and RG7652 } \\
\text { (one), 23 RCTs were included. }\end{array}$ \\
& & \\
& & \\
\end{tabular}

20 August $2020 \quad$ New search has been performed $\quad$ Evidence up to date to 2 December 2019.

\section{HISTORY}

Protocol first published: Issue 6, 2015

Review first published: Issue 4, 2017

\section{CONTRIBUTIONS OF AUTHORS}

AFS drafted the protocol, the full review, and conducted all analyses.

AFS, JPLC, LSP, JPC screened hits and extracted data.

JPLC, LSP, JTW, JPO, AH, and JPC provided guidance during critical revision of the manuscript.

\section{DECLARATIONSOF INTEREST}

AFS has received unrelated funding from Servier for the development of a genetically guided drug target validation platform. Servier does not produce a PCSK9 monoclonal antibody drug.

JPLC: none.

LSP: none.

JTW: none.

JPO: none.

$\mathrm{AH}$ is a member of the organisation committee of The Genetics of Subsequent Coronary Heart Disease Consortium and the Heart failure Molecular Epidemiology for Therapeutic Targets Consortium (HERMES) each comprising over 20 member cohorts. A number of Pharma companies have provided direct and in-kind support for these initiatives, but $\mathrm{AH}$ is not a direct recipient of any of these funds.

JPC: none. 


\section{SOURCES OF SUPPORT}

\section{Internal sources}

- No sources of support supplied

\section{External sources}

- Biomedical Research Centre, UK

This project was supported by the National Institute for Health Research University College London Hospitals Biomedical Research Centre.

- BHF, UK

AF Schmidt is supported through a BHF grant PG/18/5033837. AF Schmidt and AD Hingorani acknowledge support from the UCL BHF Research Accelerator AA/18/6/34223

- NIHR, UK

This project was supported by the National Institute for Health Research, via Cochrane Infrastructure funding to the Heart Group. The views and opinions expressed therein are those of the authors and do not necessarily reflect those of the Systematic Reviews Programme, NIHR, NHS or the Department of Health and Social Care.

\section{DIFFERENCES BETWEEN PROTOCOL AND REVIEW}

We note the following deviations from the protocol.

First review (Schmidt 2017)

- We intended to present a 'Risk of bias' figure depicting risk of bias per item, weighted for how much an individual randomised controlled trial contributed to the overall effect estimate of PCSK9 inhibitors on low-density lipoprotein cholesterol (LDL-C). However, some studies did not report on LDL-C, or did not report it at the same time point, making it impossible to present such a figure.

- Owing to the small number of events off all-cause mortality and the cardiovascular disease (CVD) endpoints, we decided against using the usual inverse variance method of pooling, which may result in biased estimates. Instead, we pooled clinical events by reconstructing individual participant data based on cell frequencies, and analysed these data using a mixed-effect generalised linear regression model with a random intercept (fixed-effect) (Bradburn 2007; Sweeting 2004).

- We meta-analysed biomarker results despite considerable heterogeneity in continuous endpoints, this contrary to the protocol statement that no meta-analysis would be performed if heterogeneity was larger than $50 \%$. We decided to combine results because estimates were universally on one side of the neutral effect.

- Owing to the small number of events, we performed all subgroup analyses for LDL-C instead of CVD. Similarly, subgroups explored were slightly different from those described in the protocol as the result of available data.

- We intended to extract data for continuous endpoints as mean percentage change from baseline, or as the difference at the end of follow-up. However, the latter was unavailable in most studies, and we focused on the former.

- Instead of data on cognitive function, we decided (post hoc) to extract data on neurological events.

This update

- Because of the robustness of the evidence, we dropped the biomarker outcomes.

- We refocused clinical outcomes on a core set, including CVD and its separate elements (provided sufficient data), all-cause mortality, influenza, hypertension, cancer diagnoses, and type 2 diabetes. We retained quality of life (despite having no data) for future exploration.

- We presented results by compound (alirocumab and evolocumab) and control group (placebo or active treatment), where terminated monoclonal antibodies (bococizumab and RG7652) were dropped from the review.

- Due to the above-mentioned reordering and removal of studies, sample size decreased for most outcomes to such an extent that subgroup analyses were no longer informative.

- Due to the unavailability of subgroup specific reports, these analyses could not be performed for clinical endpoints.

- The 2017 version of the review reported on possible heterogeneity by dosage, finding none. However, many trials changed the dosage over the run-time of the trial making such an analysis (and especially its interpretation) problematic, as such the current review does not perform a similar stratification.

- There was very little variation in observed risk of bias and percentage of missingness precluding stratified analyses to assess sensitivity.

- We added myocardial infarction and any stroke to the 'Summary of findings' tables.

- Due to performing analyses using Review Manager 5 instead of R, we no longer present random-effects estimates.

- John-Paul L Carter has joined the author team.

PCSK9 monoclonal antibodies for the primary and secondary prevention of cardiovascular disease (Review) 


\section{N D EX TERMS}

\section{Medical Subject Headings (MeSH)}

Antibodies, Monoclonal [ ${ }^{\star}$ therapeutic use]; Antibodies, Monoclonal, Humanized [therapeutic use]; Cardiovascular Diseases [ ${ }^{\star}$ prevention \& control]; Cause of Death; Cholesterol, LDL [ ${ }^{\star}$ blood]; Cholinergic Antagonists [therapeutic use]; Ezetimibe [therapeutic use]; Hydroxymethylglutaryl-CoA Reductase Inhibitors [therapeutic use]; Primary Prevention [ ${ }^{*}$ methods]; Proprotein Convertase 9 [*antagonists \& inhibitors]; Randomized Controlled Trials as Topic; Secondary Prevention [ ${ }^{\star}$ methods]; Time Factors

\section{MeSH check words}

Humans; Middle Aged 